\title{
AVALIAÇÃO DO DESAJUSTE VERTICAL E DA ESPESSURA DE PELÍCULA DE INFRA-ESTRUTURAS DE TRÊS SISTEMAS CERÂMICOS
}

Rodrigo Trentin Alves de Lima

Dissertação apresentada à Faculdade de

Odontologia de Bauru, da Universidade de São Paulo, como parte dos requisitos para obtenção do título de Mestre em Odontologia, área de Reabilitação Oral

\section{BAURU}




\section{AVALIAÇÃO DO DESAJUSTE VERTICAL E DA ESPESSURA DE PELÍCULA DE INFRA-ESTRUTURAS DE TRÊS SISTEMAS CERÂMICOS}

Rodrigo Trentin Alves de Lima

Dissertação apresentada à Faculdade de

Odontologia de Bauru, da Universidade de São Paulo, como parte dos requisitos para obtenção do título de Mestre em Odontologia, área de Reabilitação Oral

Orientador: Prof. Dr. Gerson Bonfante

\section{BAURU}




\section{RODRIGO TRENTIN ALVES DE LIMA}

03 de dezembro de 1976

Campo Grande - MS

1995-1998

$1999-2000$

2000-2002

2001-2002

2003-2005

Associações
Nascimento

Curso de graduação em Odontologia Universidade Federal de Mato Grosso do Sul - Campo Grande - MS

Curso de Aperfeiçoamento em Periodontia-Prótese - Associação Brasileira de Odontologia - Seção MS Campo Grande - MS

Curso de Especialização em Prótese Dentária - Sociedade de Promoção Social do Fissurado Labio-palatal PROFIS - Bauru - SP

Curso de Aperfeiçoamento em Implantodontia - Instituto de Ensino Odontológico - IEO - Bauru - SP

Mestrado em Odontologia, área de Reabilitação Oral, pela Faculdade de Odontologia de Bauru - Universidade de São Paulo

Associação Brasileira de Odontologia Seção MS

Sociedade Brasileira de Pesquisa Odontológica 


\section{DEDICATÓRIA}

AOS MEUS PAIS,

ARY SILVIO E CLARA AMANDA

Dedico a vocês a realização deste sonho. Serei eternamente grato pelo amor, atenção e dedicação que vocês sempre me deram.

De vocês ganhei os presentes mais importantes que um filho poderia receber: exemplos de dignidade e de vida. Cultivaram em mim os valores que transformaram uma criança em um adulto responsável e consciente.

Deram para mim a perspectiva de um futuro digno, proporcionando-me inúmeras oportunidades de estudo.

Sacrificaram seus sonhos em favor dos meus, deixaram de ter para vocês para oferecer para mim. Não existe uma forma material que eu possa retribuir seu empenho e dedicação. Quero estar ao lado de vocês por muitos anos para agradecer e recompensá-los pelos seus esforços.

Pai e mãe, do fundo do meu coração, obrigado por vocês serem assim, especiais.

Amo vocês. 
Aos meus avós maternos, Antônio e Alice, com que passei muitos anos de minha vida. De vocês pude ter sempre um colo amigo, uma compreensão quase paternal e uma dedicação inigualável. Com vocês exercitei o amor e a compaixão. Obrigado por serem tão queridos comigo.

A minha querida irmã Carla, símbolo de personalidade e exemplo de sinceridade. Obrigado por me compreender quando parecia ser impossível assim fazer. Deculpe-me quando compreender foi impossível. Te amo muito.

A minha querida Samara, com quem aprendi a ver o mundo por uma nova perspectiva, com quem me identifiquei em inúmeros aspectos e aprendi a aceitar outros tão diferentes.

Obrigado pelo carinho, tolerância, paciência, compreensão e grande simpatia. Obrigado pelas palavras de conforto e incentivo.

Sorrimos e choramos tantas vezes... Disso tudo, para mim, ficou a certeza de que você é unica. Te amo demais. 


\section{AGRADECIMENTOS}

Ao Prof. Dr. Gerson Bonfante, por ter guiado meus passos acadêmicos e ter sido sempre sincero e honesto em suas palavras. Espero poder retribuir os votos de confiança até aqui depositados com trabalho, dedicação e amizade.

Obrigado por acreditar em minha capacidade.

Meu eterno reconhecimento e gratidão pelo exemplo de homem que sempre buscou ser. 
Ao Prof. Dr. Luiz Fernando Pegoraro, que pela dedicação à docência tornouse um exemplo a ser seguido pela transmissão de sua experiência.

Ao Prof. Accácio Lins do Valle, pela amizade e conhecimento que sempre me dispensou e por acreditar em minha capacidade.

Aos amigos de mestrado Estevam, Jonas, Filipe, Mika, Thania, Lucas, Lívia, Érico, Paty, Valdey, Katia e Mariana. Sempre os considerei uma familia.

Aos professores do curso de mestrado pelos conhecimentos transmitidos e pela amizada cultivada.

Aos amigos do doutorado Eduardo Ayub, Antonio Ricardo, Rafael, Marinele, Jefferson, Luiz Gustavo, Renato, Osvaldo, Marli, Ana, Leylha, Paulo e Paulinho Fukashi.

Aos professores da Universidade Federal de Mato Grosso do Sul Antonio João da Silveira Terra, Dalva Terra, Margareth Coutinho, José Carlos Mendonça, Paulo Zárate Pereira, Marcelo Arruda, Julio Cesar Leite da Silva, José Luis Figueiredo e Eliseu Insauralde. Amigos que sempre me apoiaram em Campo Grande e incentivaram a galgar a vida acadêmica. 
Àqueles que me permitiram a pesquisa:

Ao Prof. José Roberto Pereira Lauris, pela imprescindível ajuda na análise estatística.

Ao Prof. Dr. José Gilmar Batista, pelo apoio e confecção das infra-estruturas metálicas.

Ao Laboratório Freitas, pela confecção das infra-estruturas In-Ceram Zirconia.

À Nobel Biocare, pela confecção das infra-estruturas Procera AllZircon.

Ao Sr. Ronaldo da Labordental, pela doação dos materiais de moldagem.

À Neodent, pela gravação à laser no troquel-padrão metálico.

Ao Conselho Nacional de Desenvolvimento Científico e Tecnológico CNPq, pelo fomento da bolsa de estudo durante o curso. 


\section{SUMÁRIO}

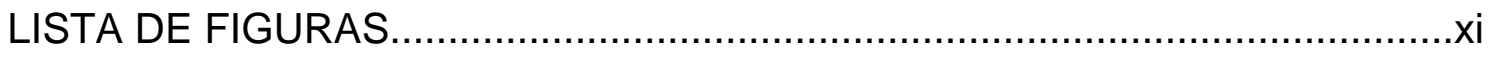

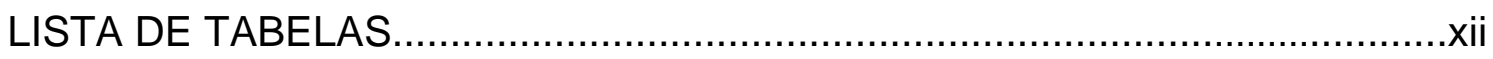

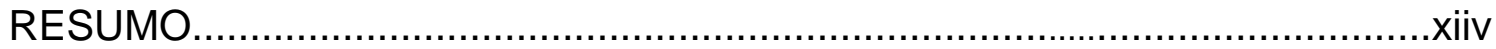

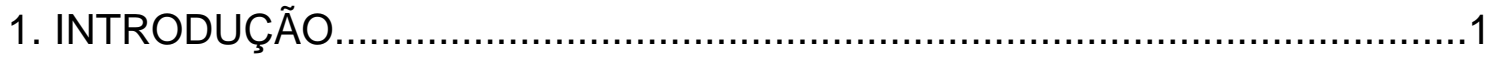

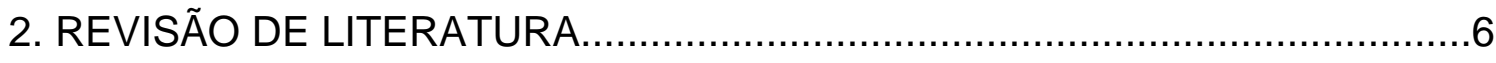

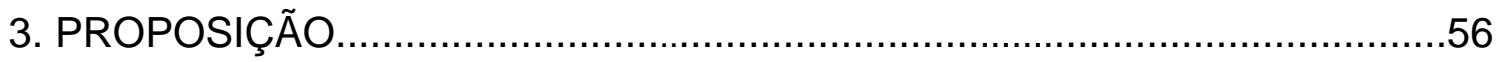

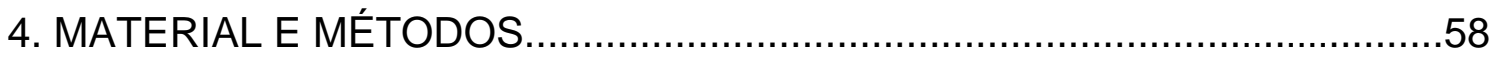

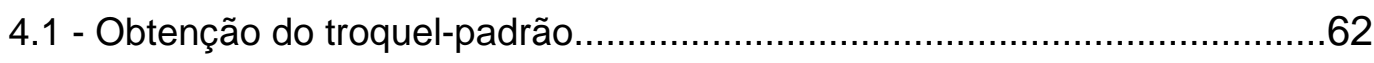

4.2 - Obtenção dos troquéis de gesso.............................................................64

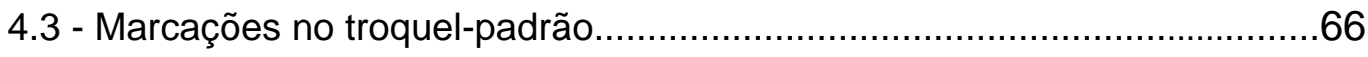

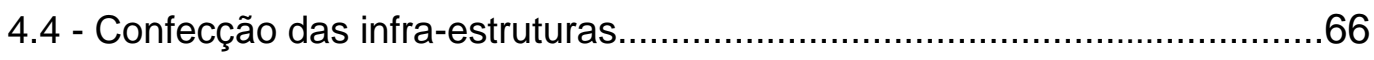

4.4.1 - Infra-estruturas metálicas para coroa metalo-cerâmica................67

4.4.2 - Infra-estruturas cerâmicas do sistema in-ceram zirconia.............69

4.4.3 - Infra-estruturas cerâmicas do sistema procera allzircon..............72

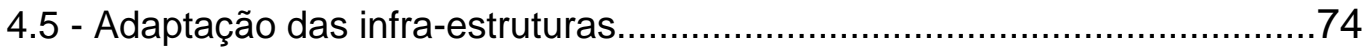

4.6 - Avaliação do desajuste vertical e da espessura de película.......................76

4.6.1 - Avaliação do desajuste vertical................................................76

4.6.2 - Captura da película de cimento-análogo.....................................78

4.6.3 - Demarcação dos pontos de leitura............................................. 80

4.6.4 - Mensuração da espessura de película de cimento-análogo em microscópio comparador........................................................... 81

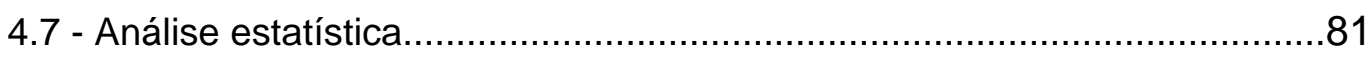

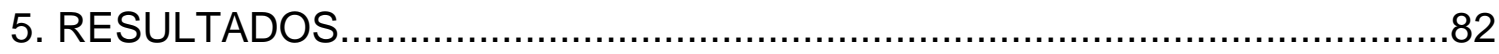

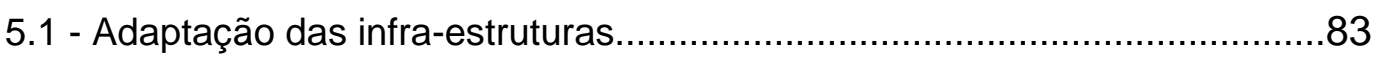

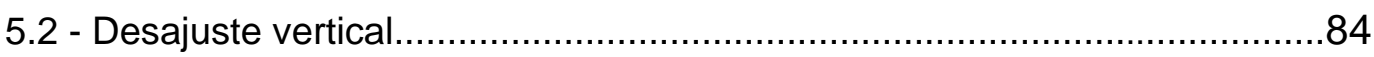

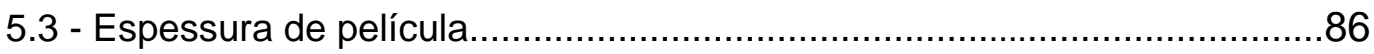

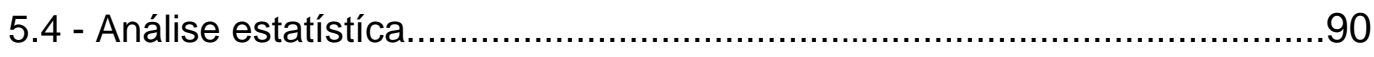

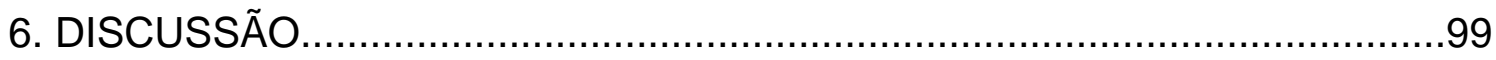




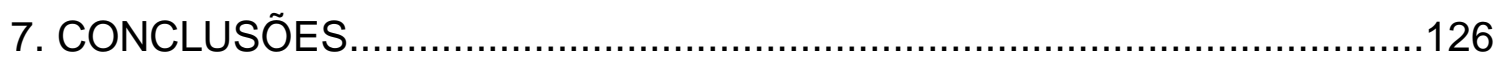

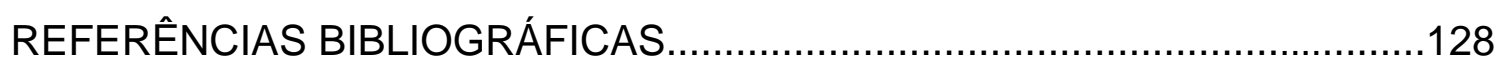

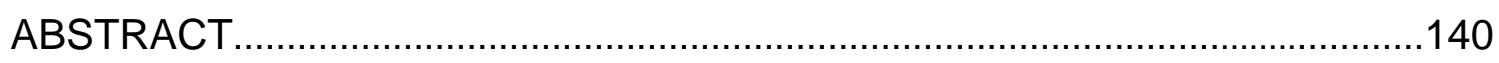




\section{LISTA DE FIGURAS}

FIGURA 4.1 - ilustração das características do preparo em vista proximal (a) e vestibular (b) e troquel-padrão metálico fundido (c)

63

FIGURA 4.2 - a) base e troquel-padrão fixados à base de resina acrílica vermelha; b) pinos na base e orifícios na plataforma do paralelômetro modificado

63

FIGURA 4.3 - a) paralelômetro modificado; b) moldeira encaixada à base de resina acrílica; c) carga estática sobre a moldeira.

.65

FIGURA 4.4 - i.e.s. assentadas sobre o troquel-padrão metálico: a) i.e. do grupo MC; b) i.e. do grupo IZ; c) i.e. do grupo PZ.

FIGURA 4.5 - i.e. do grupo PZ assentada sobre o troquel-padrão metálico sob carga estática.

.77

FIGURA 4.6 - a) película de elastômero no interior da i.e.; b) silicone de consistência média sendo injetado no interior da i.e. para captura da película.

FIGURA 4.7 - bloco de silicona seccionado ao meio no sentido vestíbulo-lingual contendo a película de elastômero em seu interior.

FIGURA 4.8 - ilustração dos pontos de leitura da espessura de película. 80

FIGURA 5.1 - ilustração das regiões correspondentes a região axio-cervical (I), axio-oclusal (II), porção superior das cúspides (III) e porção inferior do sulco mesio-distal (IV). 88

FIGURA 5.2 - representação gráfica da média de espessura dos grupos MC, IZ e PZ por ponto. .94

FIGURA 5.3 - representação gráfica da correlação entre espessura de película e desajuste vertical segundo o coeficiente de correlação de Pearson $(r=-0,26 ; p=0,173)$.

FIGURA 6.1 - representação da espessura média típica encontrada para os grupos MC (a), IZ (b) e PZ (c).

FIGURA 6.2 - exemplos de assentamento oblíquo dos grupos MC (a), IZ (b) e PZ (c) 123 


\section{LISTA DE TABELAS}

TABELA 5.1 - Média das variações verticais $(\mu \mathrm{m})$ para as faces vestibular $(\mathrm{V})$, lingual $(\mathrm{L})$, mesial (M) e distal (D) das i.es. metálicas para metalo-cerâmica. 83

TABELA 5.2 - Média das variações verticais $(\mu \mathrm{m})$ para as faces vestibular $(\mathrm{V})$, lingual $(\mathrm{L})$, mesial (M) e distal (D) das i.es. cerâmicas do sistema In-Ceram Zirconia. .84

TABELA 5.3 - Média dos desajustes verticais $(\mu \mathrm{m})$ para as faces vestibular $(\mathrm{V})$, lingual $(\mathrm{L})$, mesial (M) e distal (D), após a simulação da cimentação das i.es. metálicas para metalocerâmica.

TABELA 5.4 - Média dos desajustes verticais $(\mu \mathrm{m})$ para as faces vestibular $(\mathrm{V})$, lingual $(\mathrm{L})$, mesial (M) e distal (D), após a simulação da cimentação das i.es. cerâmicas do sistema InCeram Zirconia. .85

TABELA 5.5 - Média dos desajustes verticais $(\mu \mathrm{m})$ para as faces vestibular $(\mathrm{V})$, lingual $(\mathrm{L})$, mesial (M) e distal (D), após a simulação da cimentação das i.es. cerâmicas do sistema Procera AllZircon. 86

TABELA 5.6 - Médias de espessura de película $(\mu \mathrm{m})$ nos diferentes pontos das i.es. metálicas para metalo-cerâmica 87

TABELA 5.7 - Médias de espessura de película $(\mu \mathrm{m})$ nos diferentes pontos das i.es. cerâmicas do sistema In-Ceram Zirconia.

TABELA 5.8 - Médias de espessura de película $(\mu \mathrm{m})$ nos diferentes pontos das i.es. cerâmicas do sistema Procera AllZircon. .88

TABELA 5.9 - Médias de espessura de película $(\mu \mathrm{m})$ nas regiões I, II, III e IV das i.es. metálicas para metalo-cerâmica. 89

TABELA 5.10 - Médias de espessura de película $(\mu \mathrm{m})$ nas regiões I, II, III e IV das i.es. cerâmicas do sistema In-Ceram Zirconia .89

TABELA 5.11 - Médias de espessura de película $(\mu \mathrm{m})$ nas regiões I, II, III e IV das i.es. cerâmicas do sistema Procera AllZircon. .90

TABELA 5.12 - Desajuste vertical médio por face $(\mu \mathrm{m})$ e respectivo desvio-padrão $(\mathrm{dp}) \ldots \ldots \ldots . . . .91$

TABELA 5.13 - Teste de Tukey comparando desajuste vertical por grupo $(\mu \mathrm{m})$ .91 
TABELA 5.14 - Teste de Tukey comparando desajuste vertical por face $(\mu \mathrm{m})$

TABELA 5.15 - Resumo descritivo da espessura de película $(\mu \mathrm{m})$ por ponto, nas i.es. metálicas para metalo-cerâmica. 92

TABELA 5.16 - Resumo descritivo da espessura de película $(\mu \mathrm{m})$ por ponto, nas i.es. cerâmicas do sistema In-Ceram Zirconia. .93

TABELA 5.17 - Resumo descritivo da espessura de película $(\mu \mathrm{m})$ por ponto, em i.es. cerâmicas do sistema Procera AllZircon. .93

TABELA 5.18 - Espessura média de película para cada grupo e entre os grupos para cada região $(\mu \mathrm{m})$ e respectivo desvio-padrão $(\mathrm{dp})$ 95

TABELA 5.19 - Teste de Tukey comparando grupos, considerando as regiões I, II, III e IV.......95 TABELA 5.20 - Teste de Tukey comparando regiões, considerando os grupos MC, IZ e PZ....96 TABELA 5.21 - Espessura média de película para cada grupo e entre os grupos $(\mu \mathrm{m})$ e respectivo desvio-padrão (dp)

TABELA 5.22 - Teste de Tukey comparando espessura média de película entre os grupos $(\mu \mathrm{m})$. . .97 


\section{RESUMO}

O desenvolvimento de novos sistemas cerâmicos propicia a possibilidade de escolha do tipo de restauração que se deseje utilizar. Entretanto, os benefícios advindos deste progresso devem ser avaliados frente à possibilidade de comportamento clínico insatisfatório. Este trabalho se propõe a avaliar infra-estruturas cerâmicas quanto à influência do ajuste interno na adaptação, o desajuste vertical após a simulação da cimentação, a espessura de película nas superfícies axiais e oclusal e a ocorrência de assentamento oblíquo. Um troquel-padrão metálico com preparo para coroa total em pré-molar superior foi confeccionado e trinta troquéis de gesso foram obtidos e dividos em três grupos de dez espécimes cada. Sobre os troquéis de gesso foram confeccionadas infra-estruturas metálicas para o grupo $\mathrm{MC}$, infra-estruturas cerâmicas In-Ceram Zirconia, para o grupo IZ, e Procera AllZircon, para o grupo PZ. As infraestruturas tiveram sua posição, em relação ao troquel-padrão, mensurada durante ajuste interno e simulação da cimentação com silicone de consistência fluida (cimentoanálogo). A película de cimento-análogo abaixo das infra-estruturas foi seccionada no sentido vestíbulo-lingual e mensurada nas paredes axiais e oclusal. A análise dos resultados demonstrou que: 1) o ajuste interno das infra-estruturas metalo-cerâmicas e In-Ceram Zirconia resultou em redução do desajuste vertical; 2) o desajuste vertical das infra-estruturas Procera AllZircon foi estatisticamente diferente das infra-estruturas metalo-cerâmicas e In-Ceram Zirconia; 3) a espessura de película das infra-estruturas Procera AllZircon foi significantemente maior que das infra-estruturas metalo-cerâmicas e In-Ceram Zirconia; 4) todas as infra-estruturas apresentaram assentamento oblíquo.

Palavras-chave: sistemas cerâmicos, desajuste vertical, espessura de película, cimentação. 
1. INTRODUÇÃO 


\section{INTRODUÇÃO}

Desde a introdução da coroa de porcelana feldspática por Land, em 1886, tem existido esforço contínuo no aperfeiçoamento das coroas cerâmicas. Novos sistemas de infra-estruturas (i.es.) cerâmicas são constantemente introduzidos no mercado, modificando os conceitos de restaurações totalmente cerâmicas. Estes sistemas foram desenvolvidos para atender requisitos estéticos. Coroas assim produzidas permitiriam a passagem de luz através da restauração, diferindo-se, assim, daquelas que possuem i.es. metálicas (GIORDANO $\left.\|^{30}, 2000\right)$. Entretanto, os benefícios advindos deste progresso devem ser avaliados frente à possibilidade de desajuste e comportamento clínico insatisfatório (HOLMES et al. $\left.{ }^{38}, 1989\right)$.

Desenvolvido por Mikaël Sadoun em 1985 e disponível no mercado desde 1989, o sistema In-Ceram produz i.es. cerâmicas de alta densidade infiltradas por vidro. Este sistema consiste em dois estágios de produção. Primeiramente, a massa cerâmica é aplicada sobre um troquel refratário, por uma técnica descrita como slip casting, e sinterizada. Em seguida, esta sofre infiltração por vidro liquefeito. De acordo com o fabricante, o material estaria indicado para i.es. de coroas unitárias e próteses parciais fixas de até 3 elementos (PRÖBSTER; DIEHL ${ }^{69}$, 1992). Mais recentemente, o sistema In-Ceram Zirconia, que apresenta a adição de 33\% de óxido de zircônio acrescido ao óxido de alumínio, foi apresentado como uma variação mais resistente do sistema InCeram (GIORDANO $\left.\|^{30}, 2000\right)$.

O Sistema Procera é baseado na tecnologia CAD/CAM - Computer-Aided Design/Computer-Assisted Machining para produção industrial de i.es. cerâmicas. Inicialmente desenvolvido para criar i.es. de titânio, é capaz de criar restaurações a 
partir de óxido de alumínio e óxido de zircônio. O Sistema CAD utiliza um escandidor de troquel e um computador o qual irá converter as informações digitalizadas em pontos tridimensionais. Uma unidade de produção, por meio de um programa de computador (CAM), controla a confecção da infra-estrutura (i.e.) com cerâmica sinterizada sob alta pressão (ANDERSSON; ODÉN³ ${ }^{3}$ 1993).

Propriedades ópticas, biocompatibilidade e resistência flexural fazem das cerâmicas com óxido de zircônio, para BLATZ ${ }^{8}$ (2004), uma possível alternativa às restaurações metalo-cerâmicas. Estas cerâmicas são atualmente utilizadas em i.es. para coroas unitárias e próteses parciais fixas, intermediários de implantes e pinos intracanal. A utilização do óxido de zircônio vem sendo proposta como adição ao óxido de alumínio ou substituição do mesmo. Isto se justificaria pela melhora das propriedades mecânicas do óxido de zircônio (CHONG et al. ${ }^{15}$, 2002).

O espaço interno, compreendido entre as paredes do preparo e a superfície interna da coroa é denominado espaço pré-cimentação. O espaço tomado pelo cimento, após a cimentação, forma a linha de película do cimento, que difere e é geralmente maior do que o espaço pré-cimentação. O sucesso clínico das próteses fixas é extremamente dependente do procedimento da cimentação. Os cimentos são utilizados para auxiliar na retenção das coroas, atuar como barreira contra infiltração bacteriana e ocupar as falhas internas e marginais das restaurações (WILSON $\left.{ }^{95}, 1992\right)$. A utilização dos cimentos confronta-se sempre com a dificuldade de escoamento, quando a película deveria idealmente desaparecer da margem da coroa completamente assentada, tendo o excesso sido eliminado pela abertura marginal. Desde muito tempo credita-se à dificuldade de escoamento do cimento como o principal fator que impede o assentamento completo de uma coroa (JøRGENSEN ${ }^{42}, 1960 a$, JØRGENSEN ${ }^{43}, 1960$ b, 
JØRGENSEN; PETERSEN ${ }^{45}, 1963$, FUSAYAMA et al. ${ }^{28}, 1963$, BASSETT ${ }^{6}, 1966$ e GRAJOWER; LEWINSTEIN; ZELTSER ${ }^{32}$, 1985).

A espessura da película de cimento está relacionada a fatores ligados às propriedades dos cimentos, características do preparo dental e técnica de cimentação (WHITE; YU ${ }^{92}$, 1992b e WHITE; YU; KIPNIS ${ }^{93}$, 1992). Quanto menor o espaço précimentação, maior a influência destes fatores. Entretanto, quanto maior este espaço, maior a influência de forças incidentes sobre a película de cimento, atuando diretamente sobre a resistência desta. Ela idealmente deveria ser um espaço uniforme que não comprometesse a retenção e a forma de resistência da coroa. Entretanto, vários autores observaram grande diferença na espessura de película dentre diversos sistemas de coroas (NEIVA et al. ${ }^{58}, 1998$, MAY et al. ${ }^{55}, 1998$ e AYUB $^{5}, 2002$ ), bem como, a existência de espaço não uniforme abaixo de uma mesma coroa (JøRGENSEN ${ }^{42}$, 1960a, McLEAN; von FRAUNHOFER ${ }^{57}$, 1971, DIMASHKIEH; DAVIES; von FRAUNHOFER ${ }^{22}$, 1974, SHEARER; GOUGH; SETCHELL ${ }^{78}, 1996$ e BOENING et al. ${ }^{9}$, 2000). A espessura da linha de cimento abaixo de uma coroa pode influenciar seu prognóstico clínico (de la MACORRA; PRADÍES ${ }^{53}$, 2002). JØRGENSEN; ESBENSEN ${ }^{44}$ (1968) observaram que a resistência do cimento diminui 33\% quando sua espessura aumentou de $20 \mu \mathrm{m}$ para $120 \mu \mathrm{m}$.

A espessura de película torna-se um fator de grande importância para as i.es. cerâmicas e os diferentes processos de produção são influenciados por diferentes fatores, fazendo com que o espaço entre sua superfície interna e o troquel seja maior do que o recomendável (NEIVA et al. ${ }^{58}, 1998$, MAY et al. $.^{55}, 1998$ e AYUB $\left.{ }^{5}, 2002\right)$.

Nos recentes anos, novos agentes de cimentação têm sido introduzidos no mercado odontológico com o apelo de possuírem melhor performance clínica que os materiais já existentes. Quanto à formação de película, DIAZ-ARNOLD; VARGAS; 
HASELTON ${ }^{21}$ (1999) esclareceram que a maioria dos cimentos disponíveis atualmente é capaz de formar adequada espessura compatível com o assentamento de coroas totais. Entretanto WHITE; YU ${ }^{92}$ (1992b) e ROSENSTIEL; LAND; CRISPIN ${ }^{74}$ (1998) já haviam ressaltado que diferentes cimentos podem necessitar de diferentes espaços pré-cimentação. A maioria dos trabalhos a respeito de espessura de linha de cimento está relacionada a restaurações metálicas fundidas, sendo que pouco se sabe sobre a película sob coroas totalmente cerâmicas, sendo que a relação entre a taxa de insucesso de coroas e a espessura da linha de cimento ainda não foi estabelecida por estudos clínicos (WU; WILSON $\left.{ }^{100}, 1994\right)$.

Conhecer a espessura da película de cimento desses sistemas ceramocerâmicos, através de uma técnica não destrutiva como a do cimento-análogo (McLEAN; von FRAUNHOFER ${ }^{57}, 1971$ ), pode contribuir significativamente para o acompanhamento clínico em longo prazo de coroas assim construídas, levando à sugestão de um agente cimentante específico que evite ou minimize insucessos como fraturas e descimentação. 
2. REVISÃO DE LITERATURA 


\section{REVISÃO DE LITERATURA}

A literatura odontológica não traz consenso na nomenclatura acerca de termos como desajuste, discrepância, abertura, adaptação e desadaptação. Os termos contidos na Revisão de Literatura deste trabalho expressam a tradução das palavras dos autores. Entretanto, nas demais partes do trabalho, decidiu-se denominar adaptação o ato de ajustar a superfície interna das i.es., para que estas apresentassem o menor desajuste possível sobre o troquel. Da mesma forma, denominou-se desajuste vertical a variação adquirida pelas i.es. durante a cimentação.

Em 1907, TAGGART ${ }^{84}$ apresentou a técnica de fundição por "cera perdida" para a confecção de inlays metálicas fundidas em ouro. Apresentou, naquela data, os princípios básicos e os passos operatórios da técnica, que inclusive propunha a moldagem da cavidade, com cera fluida, diretamente na cavidade oral do paciente.

Em 1928, HOLLENBACK ${ }^{37}$ propôs a padronização de alguns passos da técnica de fundição por "cera perdida" descrita em 1907. Sugeriu princípios para o preparo da cavidade, confecção do padrão de cera, inclusão em revestimento, eliminação da cera, aquecimento do molde, fundição da liga e acabamento e cimentação da peça.

JØRGENSEN ${ }^{42}$, em 1960a, estudou em laboratório os fatores que poderiam afetar a espessura da linha de cimento em coroas totais. Para isso, com o auxílio de um torno, simulou preparos dentais em espécimes cilíndricos de plástico. Sobre eles, foram construídas coroas de bronze. O experimento teve como variáveis a pressão de cimentação, a duração da pressão de cimentação, a viscosidade da mistura, grau de convergência oclusal e perfuração oclusal da coroa. Antes da cimentação, as coroas eram colocadas em posição sobre os preparos e a distância entre o bordo da 
restauração e o bordo do término cervical era medida. Após a cimentação, esta dimensão era novamente tomada. A partir dos resultados encontrados, o autor considerou que um aumento da pressão de cimentação deveria reduzir a espessura da linha de cimento consideravelmente, e que um aumento além de $5 \mathrm{Kg}$, seria de relativa insignificância. Considerou, também, que prolongar a pressão por mais que um minuto, parece ser sem efeito. Ainda comentou, quanto à viscosidade, que quanto maior a relação pó/líquido, maior é a dificuldade de assentamento das coroas. Por fim, acrescentou que o grau de inclinação dos preparos é de grande significância quando a coroa não apresenta perfuração oclusal.

Ainda no ano de 1960b, JøRGENSEN ${ }^{43}$ estudou a estrutura do cimento de fosfato de zinco. Segundo ele, mesmo quando bem misturado, o cimento, se observado sob microscópio, apresentava pequenos grumos de pó suspensos no líquido. Alguns destes grumos podiam medir aproximadamente $100 \mu \mathrm{m}$. Porém, a maioria deles media entre $20 \mu \mathrm{m}$ e $50 \mu \mathrm{m}$. O tamanho e o número de grumos eram independentes de marca comercial ou intensidade de espatulação. A observação ao microscópio demonstrava, na maioria dos casos, que a periferia dos grumos apresentava falta de pó, predominando uma solução de ácido fosfórico. A explicação para este acontecimento seria que as partículas de pó do grumo atuariam como filtrantes da solução em seu interior, durante sua compressão. Desta forma, o líquido filtrado de dentro do grumo, espalharia a mistura do cimento que se encontra ao redor dele. Este processo de filtragem, segundo o autor, poderia levar à injúria pulpar, deficiência na retenção da restauração e inflamação periodontal, por retenção de placa no bordo da coroa. Relatou que o grau de filtragem dependeria de alguns fatores como: pressão de cimentação, período de pressão de cimentação, viscosidade do cimento, grau de convergência do 
preparo, alívio interno na coroa, perfurações na coroa e sulcos de escape para o agente de cimentação, rugosidade do preparo e forma do término cervical.

Em 1961, FUSAYAMA; IWAMOTO ${ }^{27}$ avaliaram a relação entre espessura de película e a resistência ao cisalhamento do cimento fosfato de zinco. Placas metálicas foram cimentadas sobre blocos planos de esmalte, dentina e latão e, em seguida, tracionadas. A resistência máxima ao cisalhamento foi obtida com $38 \mu \mathrm{m}$ de espessura para os espécimes de dentina, $31 \mu \mathrm{m}$ para os espécimes de esmalte e $24 \mu \mathrm{m}$, para os de latão.

FUSAYAMA et al. ${ }^{28}$ (1963) avaliaram a espessura da película de cimento de fosfato de zinco sob coroas totais e restaurações parciais metálicas fundidas. Dentes humanos, que receberam em condições laboratoriais estas restaurações, foram incluídos em resina acrílica e seccionados no sentido mesio-distal. A linha de cimento foi medida com microscópio comparador e os seguintes resultados médios foram encontrados para as coroas totais: 91 a $182 \mu \mathrm{m}$ sob a superfície oclusal, 15 a $112 \mu \mathrm{m}$ nas paredes axiais e 94 a $170 \mu \mathrm{m}$ no término cervical. As restaurações parciais apresentaram os seguintes valores médios: 31 a $111 \mu \mathrm{m}$ sob a superfície oclusal, 30 a $60 \mu \mathrm{m}$ nas paredes axiais e 18 a $84 \mu \mathrm{m}$ no término cervical.

Também em 1963, JØRGENSEN; PETERSEN ${ }^{45}$ demonstraram que os cimentos podem comprometer de forma significativa o assentamento de coroas ditas de "ajuste preciso", afirmando que quanto menores as partículas do cimento, melhor assentamento este pode permitir. Comentaram, ainda, que quanto ao tamanho das partículas, nenhum dos cimentos existentes até aquela data poderia ser considerado como ideal.

Em 1966, BASSETT ${ }^{6}$ descreveu procedimentos que garantiriam o assentamento adequado de coroas totais. Seus aconselhamentos incluíram alívio interno das coroas e 
canal de escape para o cimento, além de um ligeiro sobre-contorno marginal para garantir o selamento após o desajuste vertical produzido pela cimentação. A perfuração do canal de escape deveria, ainda, ser selada por um pino fundido em ouro.

Estudando, in vitro, restaurações tipo inlay fundidas em liga áurica, CHRISTENSEN $^{16}$ (1966) avaliou a capacidade de dez experientes cirurgiões-dentistas em determinar a adaptação marginal destas restaurações com sonda exploradora e radiografias periapicais, em áreas acessíveis e inacessíveis visualmente. Além disso, mensurou o desajuste marginal das áreas consideradas clinicamente aceitáveis por estes operadores. Os resultados mostraram que margens acessíveis somente por sonda exploradora e imagens radiográficas foram consideradas satisfatórias com aberturas de até $119 \mu \mathrm{m}$. Por outro lado, margens com acesso visual e por percepção tátil com sonda exploradora foram consideradas insatisfatórias com aberturas a partir de $26 \mu \mathrm{m}$. Houve um alto grau de variação nos escores indicados pelos cirurgiõesdentistas para as áreas acessíveis somente por sonda exploradora. Através de uma fórmula de regressão linear, foi determinado que o desajuste marginal aceitável, em áreas com acesso visual, seria de $39 \mu \mathrm{m}$. Para o autor, os operadores designados para este estudo não foram capazes de determinar de forma correta e consistente a abertura marginal de áreas acessíveis somente por sonda exploradora e imagens radiográficas.

Para avaliar a relação entre espessura de linha de cimento de fosfato de zinco e retenção de coroas totais, JØRGENSEN; ESBENSEN ${ }^{44}$ (1968) cimentaram espécimes de cobre torneados com aspectos similares a coroas e preparos dentais. A espessura de cimento no interior dos espécimes foi determinada pela diferença na altura destes antes e após sua cimentação. Após os testes de tração, os autores observaram moderada influência sobre a retenção das coroas, quanto à variação na espessura da 
película do cimento de fosfato de zinco. Houve diferença estatística apenas entre os espécimes com espessura de película de $20 \mu \mathrm{m}$ e $140 \mu \mathrm{m}$.

Avaliando próteses fixas que necessitaram de reparo ou troca, SCHWARTZ et al. ${ }^{76}$ (1970) observaram que $36,8 \%$ destas falhavam por incidência de cárie após 11,1 anos de instalação. Esta avaliação foi realizada em todas as coroas e próteses parciais fixas diagnosticadas como insatisfatórias na clínica odontológica da University of Missouri. A descimentação das mesmas ocorria em 12,1\% após 6,8 anos e margens defeituosas, que facilitavam a incidência de cárie e doença periodontal, estavam presentes em $11,3 \%$ delas após 9,7 anos.

Em 1971, CHRISTENSEN ${ }^{17}$ discutiu alguns dos progressos da época nos tratamentos odontológicos com restaurações fundidas em ouro. Estas, para ele, serviam para muitos propósitos que outros materiais restauradores não serviam até então. 0 texto traz comentários acerca de procedimentos laboratoriais e clínicos.

Ainda em 1971, McLEAN; von FRAUNHOFER ${ }^{57}$ avaliaram clinicamente a espessura da película de cimento abaixo de coroas totais e inlays. Sobre preparos dentais foram confeccionadas inlays e coroas totais metálicas em ouro, coroas metalocerâmicas e coroas de porcelana aluminizada. Cada restauração, após ser provada clinicamente e ajustada se necessário, tinha sua cimentação simulada com o poliéter Impregum ${ }^{\circledR}$. Passado o tempo de polimerização do material borrachóide, as restaurações eram removidas do interior da coroa ou do preparo dental com uma resina denominada Scutan ${ }^{\circledR}$ (ESPE, Germany). O conjunto elastômero/resina era, então, embebido em mais resina Scutan ${ }^{\circledR}$ e seccionado no sentido mesio-distal com um disco montado em peça-de-mão. Em seguida, os espécimes foram examinados sob um microscópio óptico. As medidas médias encontradas para a parede axial e parede oclusal, respectivamente, para inlays MOD foram 105,3 $\mu \mathrm{m} \pm 71,9$ e 142,0 $\mu \mathrm{m} \pm 94,6$, 
para inlays classe II foram 49,5 $\mu \mathrm{m} \pm 28,1$ e $99,5 \mu \mathrm{m} \pm 73,1$, para coroas metalocerâmicas foram $75,4 \mu \mathrm{m} \pm 38,0$ e $138,6 \mu \mathrm{m} \pm 61,9$, e para as coroas de porcelana aluminizada foram 92,9 $\mu \mathrm{m} \pm 53,1$ e $112,3 \mu \mathrm{m} \pm 66,4$. Aplicando o teste T de Student, os autores não encontraram diferenças estatisticamente significantes na espessura da película de cimento em nenhuma restauração incluída neste estudo.

DIMASHKIEH; DAVIES; von FRAUNHOFER ${ }^{22}$, em 1974, investigaram a espessura da película de cimento sob coroas totais, confeccionadas sobre troquéis de acrílico com ângulo de convergência de $2^{\circ}, 5^{\circ}$ e $10^{\circ}$. As coroas foram formadas por eletrodeposição de cobre e metade delas recebeu um sulco de escape para o cimento. O interior das coroas foi totalmente preenchido por cimento de fosfato de zinco e, em seguida, foram cimentadas sobre seus respectivos troquéis. Os conjuntos cimentados foram seccionados de forma paralela ao seu longo eixo. A espessura de película foi mensurada nos ângulos ocluso-axiais e nos terços médio e gengival das paredes axiais. Quanto ao diferente ângulo de convergência dos espécimes, observou-se que houve diferença estatística significante apenas entre aqueles com $2^{\circ}$ e $10^{\circ}$, sendo que quanto menor o ângulo, maior a espessura de película encontrada. As coroas com sulco de escape apresentaram menor espessura de película.

A especificação n.8 da AMERICAN NATIONAL STANDARDS/AMERICAN DENTAL ASSOCIATION ${ }^{2}$, revisada em 1978, traz as exigências para o cimento de fosfato de zinco tipo I (de partículas finas; indicado para cimentação de restaurações e outros usos) e II (de partículas médias; recomendado para outros usos que não cimentação de restaurações). Quanto à película do cimento, esta diz que quando o cimento tipo I é colocado entre duas placas de vidro com área de $2 \mathrm{~cm}^{2}$, sob $15 \mathrm{Kg}$ de carga, deve produzir espessura máxima de $25 \mu \mathrm{m}$. Quanto a resistência compressiva, o mesmo cimento deve, após 24 horas de presa, resistir à carga mínima de 765,3Kg/cm² . 
EAMES et al. ${ }^{23}$, em 1978, avaliaram, em laboratório, algumas maneiras de otimizar o assentamento de coroas totais e inlays. Neste experimento, as seguintes variáveis foram estudadas: grau de convergência das paredes do preparo, diferentes tipos de cimentos, perfurações oclusais, alívio interno das coroas com água-régia e alívio dos troquéis com espaçadores. Um total de 185 coroas totais e 40 inlays foram confeccionadas. No estudo com as coroas totais: 1) o grau de convergência dos preparos foi examinado com inclinações de $10^{\circ}$ e $20^{\circ}$ graus; 2) os cimentos utilizados foram: cimento de fosfato de zinco, cimento de policarboxilato, cimento de silicofosfato e cimento resinoso. As forças aplicadas durante a cimentação foram: $7 \mathrm{Kg}$ por 8 minutos, $10 \mathrm{Kg}$ por 60 segundos, $20 \mathrm{Kg}$ por 45 segundos e $27 \mathrm{Kg}$ por 15 segundos; 3) algumas coroas receberam ataque ácido com água-régia em sua superfície interna, outras foram confeccionadas com uso de espaçadores nos respectivos troquéis e outras ainda, receberam perfurações na superfície oclusal para escoamento do cimento. Dez espécimes controle para cada condição experimental permaneceram sem cimentação. No estudo com as inlays, restaurações classe II foram confeccionadas com e sem alívio do troquel e cimentadas apenas com cimento de fosfato de zinco. Alguns espécimes deste grupo também permaneceram sem cimentação. Os espécimes não cimentados eram mantidos em posição por grampos em forma de "C" e aprisionados em resina acrílica para serem seccionados. Bem como estes, os espécimes cimentados também foram seccionados. $\mathrm{O}$ assentamento das restaurações era medido em seis pontos aleatórios na superfície oclusal com um microscópio óptico. Os autores encontraram que, para as coroas totais sem alívio ou condicionamento interno, mantidas nos dentes preparados com pressão manual, existia um espaço oclusal entre a superfície interna das coroas e o preparo igual a $215 \mu \mathrm{m}$, quando o ângulo de convergência era de $10^{\circ}$. Quando este ângulo era de $20^{\circ}$, o espaço encontrado era de $99 \mu \mathrm{m}$. Nas coroas em que 
o condicionamento foi utilizado, o espaço era em torno de $50 \mu \mathrm{m}$, para as coroas de convergência $10^{\circ}$ e $20^{\circ}$, mantidas em posição por pressão manual. Nesta mesma situação, quando utilizada pressão de $15 \mathrm{Kg}$, o espaço reduziu para aproximadamente $20 \mu \mathrm{m}$. Nos preparos com grau de convergência de $20^{\circ}$ em coroas aliviadas internamente, os cimentos de fosfato de zinco e de policarboxilato produziram desajuste vertical de $33 \mu \mathrm{m}$ e $17 \mu \mathrm{m}$, respectivamente. Em coroas não aliviadas, com preparos de mesma inclinação, ambos proporcionaram desajuste vertical de $112 \mu \mathrm{m}$. Para os autores, o alívio do troquel foi considerado o mais efetivo método de otimização do assentamento de coroas ou inlays, proporcionando, inclusive, aumento na retenção das restaurações em $25 \%$.

Para avaliar a pressão intracoronal durante a cimentação de coroas totais, HOARD et al. ${ }^{35}$ (1978) criaram um troquel experimental em latão com o formato de um preparo em molar. O interior do troquel continha elementos indicadores de pressão nas pontas de cúspides, centro da superfície oclusal e paredes axiais. Cinco coroas de liga de ouro foram confeccionadas a partir deste troquel. Três tipos de cimentos foram usados durante o experimento: fosfato de zinco, policarboxilato e óxido de zinco e eugenol. Durante as repetidas cimentações, as coroas foram mantidas sob carga de 5 Kg. Os autores puderam observar que durante as cimentações houve um rápido aumento da pressão seguido de um rápido decréscimo. Para todos os cimentos testados o pico da pressão foi alcançado dentro de aproximadamente 2 segundos. Desta forma, os baixos valores residuais de pressão indicaram, segundo os autores, que o papel da pressão hidrostática poderia ter uma ação limitada na oposição ao assentamento das coroas. Os valores de pressão foram maiores para o cimento de fosfato de zinco e menores para o cimento de óxido de zinco e eugenol. O cimento de policarboxilato produziu valores intermediários. 
Também em 1978, HEMBREE; GEORGE; HEMBREE ${ }^{34}$ avaliaram a espessura de película de diversos cimentos, quando utilizados sob coroas de acrílico com e sem canal de escape. Testaram os cimentos de fosfato de zinco, silicofosfato de zinco, carboxilato, óxido de zinco e eugenol e resinoso. Ao serem cimentadas, as coroas tinham seu interior preenchido pelo cimento, antes de serem aposicionadas sobre os respectivos troquéis. Em seguida, o conjunto era seccionado. As coroas com canal de escape apresentaram menor espessura de película para a maioria dos cimentos. Para aqueles em que esta situação não ocorreu, não houve diferença estaticamente significante entre as situações com ou sem canal de escape.

Para melhor compreender as características dos cimentos de fosfato de zinco, WINDELER ${ }^{98}$ (1979) testou os efeitos sobre a espessura da película do cimento, com o aumento do volume da parte sólida e com a mistura dos componentes abaixo da temperatura ambiente. Um decréscimo na espessura da película aconteceu com a redução na temperatura da mistura e proporção pó-líquido padrão. Um aumento no volume da parte sólida do cimento, com redução na temperatura da mistura, levaram a uma espessura de cimento menor ainda.

Em 1981, ISHIKIRIAMA et al. ${ }^{40}$ investigaram a influência do volume de cimento colocado no interior das coroas totais, o uso de vibração, perfuração oclusal e ataque ácido no interior das mesmas durante sua cimentação. Dez coroas de liga de ouro tipo III foram confeccionadas a partir de padrões de cera construídos diretamente sobre um troquel metálico que representava um dente primeiro molar preparado. Representando as variáveis do estudo, metade das coroas teve seu interior preenchido totalmente por cimento fosfato de zinco e outra metade teve o mesmo cimento pincelado em suas paredes internas; aplicação de vibração com um condensador de amálgama por 10 segundos em apenas metade dos espécimes; as coroas apresentavam perfuração oclusal, ataque ácido com água-régia por cinco minutos em suas paredes internas, a 
combinação dos dois, ou nenhum deles. A mensuração do desajuste foi feita através de um indicador que media a posição vertical das coroas antes e após sua cimentação sob carga estática de $9 \mathrm{~kg}$. A maior discrepância foi identificada quando o interior das coroas foi completamente preenchido pelo cimento. Tanto vibração, quanto perfuração oclusal e ataque ácido com água-régia produziram melhora semelhante e positiva no assentamento das coroas.

No ano de 1982, ARAKELIAN ${ }^{4}$ relatou uma maneira bastante prática de ajuste interno de coroas. Ele propôs que a simulação da cimentação das i.es., com o auxílio de um material elástico de moldagem (silicone) em seu interior, seria de sobremaneira eficiente, no mapeamento tridimensional do espaço interno de uma coroa cimentada. Comentou, ainda, que outras técnicas não seriam capazes de demonstrar da mesma maneira nítida e simples o ajuste interno de uma coroa.

Ainda em 1982, DEDMON ${ }^{19}$ avaliou a concordância intra e inter-examinadores na identificação de desajustes marginais não-visíveis. A avaliação contou com seis experientes indivíduos que, com uma sonda exploradora e os olhos vendados, avaliaram uma fresta horizontal em um dispositivo metálico preparado para o estudo. A fresta tinha suas projeções horizontal e vertical aumentadas gradualmente e cada examinador apontava quando aquela discrepância era considerada inaceitável, como abertura marginal de uma coroa. Cada examinador repetiu a avaliação dez vezes. A média encontrada para o grupo quanto a abertura vertical foi de $114 \mu \mathrm{m}$ e quanto a abertura horizontal, de $93 \mu \mathrm{m}$. Os autores completaram que os indivíduos tiveram ampla divergência de resultados inter e intra-examinadores.

RISSIN; WETREICH ${ }^{72}$ (1983) sugerem a utilização de silicone de baixa viscosidade (Xantopren) como evidenciador de contatos internos no ajuste clínico de coroas totais. Segundo eles, a coroa deveria ser levada sobre o dente, com o material 
colocado em seu interior, simulando sua cimentação. Após o tempo de presa do material, remover-se-ia a coroa do seu lugar de assentamento e seu interior seria inspecionado. As áreas que apresentassem descontinuidade ou espessura muito reduzida do material evidenciador deveriam ser ajustadas. O procedimento poderia ser repetido até o completo assentamento da coroa sobre o dente.

Para estudar o assentamento de coroas totais durante sua cimentação, PASCOE $^{62}$ (1983) construiu duas réplicas bi-dimensionais de preparos dentais e respectivas coroas e as cimentou com cimento de fosfato de zinco. Uma das réplicas tinha o término cervical em ombro e a outra, em ombro biselado. A partir destas simulações, ele observou assentamento simétrico das coroas, com o término cervical em ombro promovendo melhores resultados quando comparado ao ombro biselado.

GRAJOWER; LEWINSTEIN ${ }^{31}$, ainda em 1983, avaliaram matematicamente o efeito compensatório da expansão dos revestimentos para fundição e o espaço de alívio no ajuste de coroas fundidas com diferentes preparos dentais. Eles demonstraram que uma adaptação adequada, somente pode ser obtida quando houver espaço suficiente para a película de cimento. Porém, materiais de revestimento com expansão descontrolada levariam, invariavelmente, a desajuste inaceitável das coroas. Desta forma, eles consideraram necessário o cálculo específico de expansão do revestimento para cada tipo de restauração e respectiva liga metálica.

FRANSSON; ØILO; GJEITANGER ${ }^{26}$, em 1985, propuseram-se a estudar, in vitro e in vivo, o espaço interno de coroas metalo-cerâmicas após a simulação de sua cimentação. Esta simulação, no presente estudo, foi feita tanto sobre o troquel que deu origem à coroa, quanto sobre o dente que recebeu a restauração, utilizando um elastômero de consistência leve (silicone de condensação). Foram selecionadas aleatoriamente em duas escolas de odontologia da Alemanha, cinqüenta e cinco coroas metalo-cerâmicas feitas de ligas áureas (38 em Gotemburgo e 17 em Oslo). Após a 
simulação das cimentações e o elastômero ter finalizado sua reação de presa, as coroas eram removidas de seu local de assentamento e a película de silicone era removida do troquel (com o auxílio de resina epóxica) ou do interior da coroa (com a ajuda de uma massa de silicone pesada). Em seguida, o conjunto era seccionado no sentido vestíbulo-lingual com o auxílio de um disco de diamante, quando usada a resina epóxi, ou com uma lâmina de bisturi, no conjunto de silicone. As medições foram feitas sob um microscópio óptico, em áreas correspondentes às margens cervicais e paredes axiais das faces vestibular e lingual e no ponto médio da face oclusal/incisal das coroas. Os autores encontraram uma discrepância de 20 \% mais na espessura de linha de cimento para a cimentação sobre os dentes, em relação à cimentação sobre os troquéis. Encontraram, também, uma espessura média abaixo de $100 \mu \mathrm{m}$ nas paredes axiais e abaixo de $150 \mu \mathrm{m}$ nas margens. Puderam observar, inclusive, que as coroas oriundas da escola de Oslo, eram significantemente mais desajustadas que as coroas da escola de Gotemburgo.

Com o objetivo de investigar a elevação de coroas totais durante sua cimentação e a espessura mínima de cimento produzida neste ato, GRAJOWER; LEWINSTEIN; ZELTSER $^{32}$ (1985) utilizaram coroas metálicas fundidas em liga básica, construídas a partir de treze molares e pré-molares humanos preparados para este fim. A altura dos conjuntos de coroa e dente preparado, mantidos sob carga de $10 \mathrm{Kg}$, foi medida antes e após a cimentação destes com cimento de fosfato de zinco. Em seguida, os espécimes cimentados foram seccionados e a espessura mínima do cimento foi mensurada sob microscópio com 100 vezes de aumento. As cimentações resultaram em elevação média das coroas em $54 \mu \mathrm{m}(-8 \mu \mathrm{m}$ a $113 \mu \mathrm{m})$. A espessura mínima do cimento encontrada foi de $4,7 \mu \mathrm{m}$. As variações encontradas na espessura de cimento para as 
paredes axiais foram atribuídas principalmente a rugosidades da superfície interna das coroas e ao assentamento oblíquo das mesmas.

Em 1986, SCHWARTZ ${ }^{77}$ apresentou uma revisão da literatura a respeito dos métodos e técnicas para se melhorar a adaptação de restaurações fundidas. Revisou considerações acerca dos preparos dentais, da película de cimento sob as coroas, dos materiais dentários na confecção das coroas e dos métodos para otimizar a adaptação e o assentamento das restaurações.

Através de uma simulação em computador, KAY; JABLONSKY; DOGON ${ }^{49}$ (1986) desenvolveram uma abordagem teórica que demonstrava os fundamentos das influências sobre a adaptação e a cimentação de coroas. Os resultados demonstraram: 1) que diferentes tipos de términos cervicais levavam a diferentes graus de assentamento das coroas; 2) que quanto maior a pressão aplicada durante a cimentação, melhor o assentamento; 3) e que a incorporação de espaço entre as coroas e as paredes axiais e oclusal dos preparos levava ao melhor assentamento e adaptação marginal delas.

Sob a hipótese de que o escoamento dos cimentos seja influenciado pelo desenho das superfícies pelo qual eles escoam, ØILO; EVJE ${ }^{60}$ (1986) testaram a espessura de película de seis diferentes cimentos quando comprimidos entre superfícies planas e quando entre um dente e uma coroa. Os cimentos testados foram: cimento de fosfato de zinco (De Trey Zinc), cimento de policarboxilato (Durelon e Ceramco) e cimento de ionômero de vidro (Fuji I, Aqua Cem e Ketac Cem). Estes foram colocados, sob carga, entre duas placas de vidro (modelo 1) e no interior de um sistema de coroa e análogo de resina acrílica (modelo 2). Os resultados demonstraram diferenças estatísticas na espessura de película quando os diferentes modelos foram aplicados, sendo observada menor espessura sob o modelo 2. Os autores propuseram, 
ainda, uma explicação baseada em conceitos reológicos para a diferença nos resultados obtidos.

BOLOURI; MARKER; SARAMPOTE ${ }^{10}$ (1987) avaliaram a possibilidade do método de aplicação de cimento influenciar na espessura de sua película, no interior das coroas totais. Utilizaram vinte coroas fundidas em liga áurica, cimentadas sobre seus respectivos troquéis de gesso, sob carga de $11,35 \mathrm{~kg}$, com cimento de policarboxilato. As coroas foram confeccionadas sem alívio nos troquéis e não sofreram qualquer ajuste interno após sua fundição. Duas situações de aplicação do cimento foram testadas. Em uma delas, o cimento foi aplicado com uma espátula na superfície interna das coroas. Em outra, a aplicação foi feita com um pequeno pincel sobre as paredes dos troquéis. Os espécimes foram seccionados em seu longo eixo e a espessura da linha de cimento, sob a superfície oclusal, foi mensurada. Naquelas coroas em que o cimento foi aplicado com a espátula, a película de cimento tinha, em média, $1.900 \mu \mathrm{m}$. Para aquelas cuja aplicação se fez com pincel sobre os troquéis, a média foi de $400 \mu \mathrm{m}$, mostrando a superioridade desta técnica sobre a outra para o cimento de policarboxilato.

Utilizando dois diferentes desenhos de estudo, IIZUKA et al. ${ }^{39}$ (1987) avaliaram a relação entre a espessura de película e a retenção dos cimentos de fosfato de zinco, policarboxilato e ionômero de vidro. Duas marcas comerciais de cada um dos cimentos foram testadas entre placas de vidro e em pares de troquéis e coroas com e sem sulco de escape para o cimento. Os resultados apontaram que as coroas cimentadas com sulco de escape produziram menor espessura de película, independentemente do cimento, seguidas do modelo com placas de vidro. As coroas cimentadas sem sulco de escape produziram a maior espessura de película dentre as situações testadas, 
também independentemente do cimento. Observou-se que quanto menor a espessura de película produzida pelos modelos, maior a retenção dos mesmos frente à tração.

Ainda em 1987, MARKER et al. ${ }^{54}$ avaliaram o efeito dos espaçadores de troquel e da textura superficial dos preparos na retenção e adaptação de coroas totais. Eles puderam observar que coroas confeccionadas sobre troqueis aliviados, após a cimentação, assentavam-se melhor e possuíam maior retenção, do que aquelas não aliviadas. Moderada rugosidade superficial sobre os preparos também melhorava a retenção das coroas.

Quanto ao assentamento incompleto de coroas após sua cimentação, em 1988, PILO et al. ${ }^{65}$ apresentaram uma revisão da literatura pertinente ao assunto até aquele momento. Foram abordados assuntos como espessura da linha de cimento, teorias que explicariam o assentamento incompleto, discrepâncias marginais, técnicas de cimentação e alívio interno.

ROSENSTIEL; GEGAUFF ${ }^{73}$ (1988) propuseram-se a avaliar em laboratório a influência da carga dinâmica, durante a cimentação, no assentamento de coroas totais. Dois molares extraídos mantidos em água foram preparados em um torno com as mesmas dimensões. Estes foram moldados com silicone de adição, e os troquéis produzidos foram aliviados com espaçador Tru-Fit ${ }^{\circledR}$. Coroas totais metálicas foram construídas e ajustadas. Após isto, os troquéis foram embebidos em resina, seccionados e a espessura do espaçador, medida sob microscópio óptico em oito pontos. Quatro pontos eqüidistantes foram feitos próximo à região cervical das coroas e outros quatro, feitos nos dentes, em locais correspondentes aos primeiros. Cada coroa foi assentada sem cimento e a distância entre os pares de pontos foi medida, também, sob microscópio óptico. As coroas eram cimentadas com fosfato de zinco. Inicialmente assentadas com ligeira rotação axial e mantidas sob pressão digital. Em seguida, ambos os dentes receberam carga de $49 \mathrm{~N}$ de forma dinâmica e estática, sob um 
bastão de laranjeira apoiado sobre a superfície oclusal das coroas. Quando representavam o grupo de força dinâmica, o bastão de laranjeira era movimentado horizontal e verticalmente, por 30 segundos. Quando representavam o grupo de força estática, o bastão permaneceu imóvel. Os espécimes permaneciam imersos em água por 24 horas e os pares de pontos eram medidos novamente. Após isto, eram levados à máquina de testes servo-hidráulica que separava as coroas de seus dentes. O cimento era removido dos dentes preparados e das coroas. Os espécimes eram, então, limpos e novamente medidos e recimentados. Um total de 20 cimentações foi realizado. Subseqüentemente, o espaço entre as coroas e os dentes preparados foi medido pela técnica do cimento-análogo. A simulação da cimentação de cada coroa foi feita com silicone de adição. Em seguida, a película de material formada abaixo das coroas, era seccionada e levada ao microscópio óptico para medição. A discrepância vertical média, quando aplicada força estática foi igual a $203 \mu \mathrm{m}$ e quando aplicada força dinâmica, -14 $\mu \mathrm{m}$. A força de retenção média foi de $168 \mathrm{~N}$ para a carga estática e 143, para a dinâmica, sendo considerada pelos autores, como estatisticamente insignificante. A espessura média do espaçador foi igual a $55 \mu \mathrm{m}$ e $66 \mu \mathrm{m}$ para o dente A e para o dente $B$, respectivamente. Da mesma forma, a espessura média da linha de cimento foi igual a $92 \mu \mathrm{m}$ para o dente A e $82 \mu \mathrm{m}$ para o dente B. Os autores concluíram que as coroas parecem assentar-se melhor quando uma força dinâmica de $49 \mathrm{~N}$ é aplicada sobre elas. Atribuíram o fato da força estática ter produzido discrepância de mais de $200 \mu \mathrm{m}$ ao íntimo contato entre superfícies da coroa e do preparo.

Observando a dificuldade encontrada na mensuração das margens de coroas, HOLMES et al. $^{38}$ (1989) sugeriram uma padronização na terminologia adotada para classificar o desajuste marginal. Sugeriram que a combinação angular da abertura marginal e a sobre-extensão ou sub-extensão da margem da coroa seja chamada de 
discrepância marginal absoluta. De outra maneira, esta também poderia ser definida como a combinação angular da discrepância marginal vertical com a discrepância marginal horizontal. Para eles, a discrepância marginal absoluta representaria sempre a maior medida de erro da margem, representando o desajuste total daquele ponto.

Também em 1989, ABBATE; TJAN; FOX ${ }^{1}$ avaliaram em laboratório a adaptação marginal de quatro sistemas de coroas (metalo-cerâmica convencional, metalocerâmica com bordo vestibular em cerâmica, coroas Cerestore e Dicor) após sua cimentação. Utilizaram dez (troquéis) preparos para cada grupo, obtidos a partir de 2 tipos de troquéis-padrão (um para as coroas metalo-cerâmicas e outro para as coroas puras de cerâmicas). As coroas, obtidas pelas técnicas de cada sistema, foram cimentadas com cimento de fosfato de zinco sobre seus respectivos troquéis. Em seguida, foram incluídos em anéis que continham resina epóxi e seccionados no sentido vestíbulo-lingual em 3 partes, por meio de 2 cortes. Estes foram feitos a aproximadamente $1 \mathrm{~mm}$ do centro de cada uma das faces vestibular e lingual da coroa. As medições foram feitas com um microscópio com micrômetro digital, acoplado a um sistema de vídeo que projetava as imagens na tela de um televisor de alta definição. Não foram encontrados resultados estatisticamente significantes na adaptação marginal das coroas estudadas. As coroas Cerestore apresentaram o menor desajuste médio $(44,1 \mu \mathrm{m})$, enquanto as coroas Dicor apresentaram o maior desajuste médio $(65,3 \mu \mathrm{m})$. As coroas metalocerâmica com bordo vestibular em cerâmica apresentaram desajuste de $57,0 \mu \mathrm{m}$ e as coroas metalocerâmicas convencionais, $60,6 \mu \mathrm{m}$.

Em um trabalho laboratorial, KELLY; DAVIS; CAMPBELL ${ }^{50}$ (1989), mostraram um método não-destrutivo de mapeamento do desajuste interno de coroas de ouro tipo III. Para isso, propuseram que a espessura do material que simula a cimentação (silicone de condensação de consistência fluida), como cimento-análogo, poderia ser 
determinada pela medição da intensidade de luz que o transpusesse. Para demonstrar a proposição, realizaram três experimentos: no primeiro deles (experimento 1), amostras de silicone de condensação de consistência fluida, com espessuras previamente medidas por um micrômetro, foram medidas fotometricamente com um equipamento óptico capaz de medir a intensidade de luz que transpõe materiais coloridos. No segundo experimento (experimento 2), dez coroas de ouro tipo III foram produzidas sobre troquéis de resina epóxi. A superfície interna das coroas foi jateada com óxido de alumínio e sua cimentação foi simulada sobre os troquéis de resina, utilizando o mesmo material análogo ao cimento descrito acima. As coroas foram removidas dos troquéis e a película de silicone, que em todas as coroas permaneceu no interior da peça, teve sua espessura medida em um ponto aleatório pelo equipamento óptico fotométrico. O ponto de leitura foi marcado em todas as peças e, então, a película foi seccionada e levada ao microscópio óptico. No terceiro experimento (experimento 3), a espessura de película de cimento-análogo, abaixo de 7 coroas, foi fotometricamente obtida em 45 pontos por coroa. As mesmas coroas foram cimentadas com cimento de fosfato de zinco sobre seus troquéis e, em seguida, seccionadas. A linha de cimento foi medida em um microscópio óptico em 10 pontos, que buscavam semelhança em seu posicionamento com as medições fotométricas. $\mathrm{O}$ experimento 1 demonstrou que existe relação entre a espessura de película e a capacidade de transposição da luz através do silicone, ou seja, a capacidade da luz atravessar a película colorida de silicone diminui na mesma proporção que a espessura aumenta. 0 experimento 2 mostrou que ao avaliar a espessura de cimento-análogo sob as coroas, a relação entre a capacidade de medição do equipamento fotométrico e as medidas do micrômetro do microscópio óptico mantém a mesma razão do experimento 1. O terceiro experimento também demonstrou relação entre as medidas fotométricas do cimentoanálogo e a espessura do cimento de fosfato de zinco. Os autores concluíram que as 
medições fotométricas pareciam ser uma técnica válida de mapeamento tridimensional da adaptação de coroas.

Com o objetivo de melhorar o assentamento e selamento marginal de coroas totais, DAVIS; KELLY; CAMPBELL ${ }^{18}$ (1989) avaliaram um material elastomérico fluido de moldagem (Xantopren) como ferramenta de ajuste interno. Dezoito coroas foram confeccionadas a partir de troquéis de resina acrílica e divididas em dois grupos. Apenas um dos grupos (grupo experimental) recebeu ajuste interno com Xantopren. As áreas em que ocorria contato muito próximo entre as paredes internas das coroas e as respectivas áreas dos troquéis eram ajustadas. Todas as coroas tiveram o selamento marginal mensurado em oito pontos pré-definidos em suas margens, através de um microscópio óptico. As coroas do grupo experimental tiveram o selamento marginal mensurado antes e após o uso do Xantopren; as coroas restantes (grupo controle) foram mensuradas da mesma forma, sem o elastômero em seu interior. Para avaliar se o mesmo material elastomérico poderia ser utilizado como material adequado para simulação de cimentação, suas propriedades de escoamento e linha de cimento foram comparadas às do cimento de fosfato de zinco. Para isso, simulou-se a cimentação das coroas do grupo controle com o material elastomérico e o selamento marginal foi mensurado. Para as coroas do grupo experimental, valores semelhantes foram extraídos daqueles obtidos após o ajuste interno das mesmas. Após isto realizado, todas as coroas foram cimentadas com cimento de fosfato de zinco, tendo seu selamento marginal medido. Estas foram seccionadas e a linha de cimento medida em dez pontos nas superfícies oclusal e axiais, bem como na margem cervical. Os resultados apontaram melhora em média de $91 \mu \mathrm{m}$ no selamento marginal das coroas do grupo experimental. Os valores de selamento marginal obtidos com Xantopren foram semelhantes àqueles obtidos com o cimento de fosfato de zinco. Os autores ainda relataram que a espessura de película sob as coroas não foi uniforme. 
Ao avaliar a influência do número de camadas de espaçador Tru-Fit sobre o grau de assentamento e retenção de coroas totais, GEGAUFF; ROSENSTIEL ${ }^{29}$ (1989) encontraram valores negativos de assentamento destas após sua cimentação. Porém, não houve diferença estatística significante para o assentamento quando utilizadas de 1 a 6 camadas do espaçador. Apenas aquelas confeccionadas sem o uso do mesmo apresentaram retenção estatisticamente superior às demais.

No mesmo ano de 1989 , SORENSEN ${ }^{79}$ descreveu o processo de formação de placa bacteriana e resposta gengival ao redor de restaurações protéticas. Para ele seria necessária a presença de uma superfície dental o mais lisa possível em contato com o tecido gengival. Quando a integridade desta lisura superficial fosse quebrada por, por exemplo, um imperfeito selamento marginal de uma coroa, resultaria em um rápido acúmulo de placa bacteriana. Uma vez as bactérias tendo conseguido um nicho na margem gengival e sendo a higiene oral insatisfatória, a proliferação da placa ocorreria, induzindo à inflamação gengival. Esta desadaptação cervical possibilitaria ao cimento ocupar este espaço. Sua superfície rugosa favorece ainda mais a colonização bacteriana. Quanto maior a discrepância marginal, mais pronunciada seria a reação gengival. $\mathrm{O}$ autor finalizou dizendo que os seguintes fatores interferem no acúmulo de placa na interface dente/restauração: rugosidade superficial, ajuste marginal e contorno.

Em 1990, SORENSEN ${ }^{80}$ apresentou um método para medição da adaptação marginal de coroas totais. As coroas utilizadas para o experimento foram cimentadas sobre troquéis metálicos, sob força de 6 libras, e seccionadas no sentido vestíbulolingual e mesio-distal. Em seguida, os espécimes foram fotografados com $120 \mathrm{X}$ de aumento. De maneira padronizada no estudo, os pontos e angulações que representavam desajuste marginal das coroas em relação ao término dos preparos foram medidos com escalas milimetradas transparentes. De forma independente, três 
observadores fizeram as medições das discrepâncias horizontal e vertical das margens. A variação entre os observadores foi, segundo o autor, de $10 \mu \mathrm{m}$.

Para estudar a deformação das coroas durante a cimentação, WILSON et al. ${ }^{94}$ (1990) utilizaram aferidores de pressão posicionados circunferencialmente na margem cervical de dez coroas de liga de ouro tipo III. As coroas foram fundidas a partir de padrões de cera construídos diretamente sobre um troquel padrão metálico. Cinco delas tinham a espessura de suas paredes axiais de 0,3 $\mathrm{mm}$ e as outras cinco, $1 \mathrm{~mm}$. Elas foram cimentadas sobre o mesmo troquel metálico com cimento de fosfato de zinco e silicone fluido (com diferentes viscosidades), sob carga de $53 \mathrm{~N}$. Os resultados mostraram que quanto maior a viscosidade dos fluidos, maior a deformação e maior o tempo de assentamento das coroas. Mostraram também, que quanto mais finas as coroas, maior a deformação. As coroas mais espessas $(1 \mathrm{~mm})$ assentaram mais vagarosamente $(73 \%$ mais tempo) que as mais finas $(0,3 \mathrm{~mm})$.

WEAVER; JOHNSON; BALES ${ }^{88}$ (1991) compararam a adaptação marginal de dois tipos de cerâmicas fusíveis (Cerestore e Dicor) e de coroas metalo-cerâmicas, antes e após sua cimentação. Vinte incisivos centrais superiores preparados com término cervical em ombro de $90^{\circ}$ deram origem a dez coroas Cerestore e dez coroas Dicor. Outros dez incisivos centrais superiores, preparados com término cervical em ombro biselado, deram origem a dez coroas metalo-cerâmicas utilizando liga de ouro. Todas as coroas foram assentadas sobre seus respectivos dentes preparados e a adaptação marginal mensurada nas faces vestibular, lingual, distal e mesial. Estas foram, então, cimentadas com cimento de fosfato de zinco; as coroas cerâmicas sob peso de $8 \mathrm{Kg}$ e as coroas metalo-cerâmicas, sob $25 \mathrm{Kg}$. Mais uma vez a adaptação marginal foi mensurada nos mesmos pontos de referências utilizados anteriormente. Antes da cimentação, as coroas Cerestore e metalo-cerâmicas apresentavam abertura marginal de $21,6 \mu \mathrm{m}$ e $30,5 \mu \mathrm{m}$, respectivamente. As coroas Dicor apresentavam 
abertura marginal igual a 44,4 $\mu \mathrm{m}$. Após a cimentação, os valores foram iguais a 31,7 $\mu \mathrm{m}$ para coroas Cerestore, $57 \mu \mathrm{m}$ para coroas Dicor e $58,8 \mu \mathrm{m}$ para coroas metalocerâmicas. Em seguida, todas as coroas foram seccionadas no sentido vestíbulolingual. A espessura da linha de cimento foi medida e os valores encontrados foram: 25 $\mu \mathrm{m}$ para as coroas metalo-cerâmicas, $37 \mu \mathrm{m}$ para coroas Cerestore e $61 \mu \mathrm{m}$ para coroas Dicor. Os autores também concluíram que a adaptação marginal não foi melhorada nos preparos biselados e com força de assentamento acentuada.

Através de um estudo retrospectivo, FELTON et al. ${ }^{24}$ (1991) demonstraram a relação quantitativa entre adaptação marginal de coroas totais e a saúde do tecido periodontal. Quarenta e duas coroas metálicas fundidas, em função por 8,6 anos em média (de 4 a 18,5 anos) e com margens localizadas subgengivalmente, foram avaliadas. Para a avaliação, a margem vestibular de cada uma das coroas foi moldada com silicone de adição, dando origem a troquéis de gesso. Estes foram metalizados e a discrepância marginal entre coroa e dente foi avaliada sob microscópio de varredura. Índices periodontais (inflamação e volume de fluido gengival e profundidade de sondagem) e restauradores (percepção tátil com sonda exploradora) foram levantados clinicamente para a face vestibular de todas as coroas. Os resultados demonstraram uma alta significância entre inflamação gengival e discrepância marginal e entre volume de fluido gengival e discrepância marginal; quanto maior o desajuste marginal, maior a inflamação e maior o volume de fluido gengival. Nenhuma correlação significante foi observada entre discrepância marginal e profundidade de sondagem.

Com o objetivo de determinar a efetividade do evidenciador de contatos internos à base de silicone GC Fit-Checker no ajuste marginal de coroas totais, WHITE; SORENSEN; KANG ${ }^{90}$ (1991) utilizaram 42 coroas metálicas fundidas em liga básica, construídas a partir de pré-molares humanos preparados para este fim. A coroas foram 
posicionadas sobre seus respectivos dentes, recebendo carga de $5 \mathrm{Kg}$. Estas tiveram sua abertura marginal em relação ao término do preparo mensurada em um ponto para as faces vestibular, lingual, mesial e distal. Em seguida, as coroas foram removidas dos dentes, ajustadas com o evidenciador à base de silicone e a abertura marginal foi mais uma vez mensurada da mesma forma. A média da abertura marginal antes do ajuste foi igual a $92 \mu \mathrm{m}$ e após o ajuste, $55 \mu \mathrm{m}$. Portanto, houve redução média na abertura marginal de $37 \mu \mathrm{m}(39 \%)$, sendo os resultados estatisticamente significantes.

Ao cimentar as extremidades de cilindros fundidos em liga de níquel-cromo, com um cimento resinoso (Panavia Opaque), DIAZ-ARNOLD; WILLIAMS; AQUILINO20 (1991) buscavam observar a relação entre a espessura de cimento dos espécimes e a resistência à tração dos mesmos. As espessuras de película testadas foram de $20 \mu \mathrm{m}$, $50 \mu \mathrm{m}, 80 \mu \mathrm{m}, 110 \mu \mathrm{m}, 140 \mu \mathrm{m}$ e $200 \mu \mathrm{m}$. Após terem passados por termociclagem, os espécimes foram tracionados. Observou-se que aqueles com película igual a $80 \mu \mathrm{m}$ apresentaram os maiores valores de resistência à tração, sendo os únicos com diferença estatística significante em relação aos demais.

Ainda em 1991, TROENDLE; TROENDLE; CAVAZOS ${ }^{86}$ avaliaram a espessura de película produzida por 4 diferentes agentes reveladores de contato interno: cera reveladora Kerr, Ney Spray, GC Check Fit e silicone de adição fluida (Extrude). O experimento foi realizado de acordo com a especificação n.8 da AMERICAN NATIONAL STANDARDS/AMERICAN DENTAL ASSOCIATION. A película produzida pelo material Ney Spray teve espessura média de $17 \mu \mathrm{m}$. Os demais materiais produziram película com, em média, $3 \mu \mathrm{m}$ de espessura.

Em 1992, PRÖBSTER; DIEHL ${ }^{69}$ apresentaram o sistema In-Ceram que combina os processos de sinterização e infiltração por vidro para se obter uma i.e. cerâmica. Partículas de óxido de alumínio são sinterizadas, formando uma estrutura porosa que 
será infiltrada por vidro fundido. A combinação destes dois processos dá ao material, segundo os autores, suas excelentes propriedades. O processo de sinterização acontece praticamente sem contração, provendo boa adaptação marginal, enquanto que a infiltração pelo vidro não deixa porosidades, resultando em alta resistência. $O$ artigo descreveu os procedimentos técnicos e clínicos do sistema, além de discutir indicação, resistência flexural e integridade marginal de suas i.es.

No intuito de estudar a influência das terminações cervicais no assentamento de coroas totais, BYRNE ${ }^{11}$ (1992) investigou o espaço axial de coroas assentadas sobre os preparos dentais. Três preparos dentais idênticos para metalo-cerâmica foram realizados em incisivos centrais com diferentes términos cervicais vestibulares (ombro, ombro-biselado e chanfrado). Os preparos foram moldados e deram origem a 45 troquéis de resina epóxica (15 para cada tipo de término cervical). Cada um destes foi moldado novamente, dando origem a 45 troquéis de gesso. Quinze coroas foram produzidas para cada tipo de término cervical, onde 5 foram assentadas sobre seu troquéis de gesso, 5 foram assentadas sobre os troquéis de resina epóxica e outras 5 , cimentadas com cimento de fosfato de zinco sobre os respectivos troquéis de resina epóxica. Cada um dos espécimes foi seccionado no sentido vestíbulo-lingual no centro das coroas. Considerando as três situações de aposição das coroas sobre os troquéis e os três diferentes términos cervicais vestibulares, o desajuste marginal vestibular variou entre $12 \mu \mathrm{m}$ e $24 \mu \mathrm{m}$, o desajuste marginal lingual variou entre $6 \mu \mathrm{m}$ e 22,8 $\mu \mathrm{m}$ e o desajuste axial, entre 38,2 $\mu \mathrm{m}$ e 62,6 $\mu \mathrm{m}$. Análise estatística demonstrou não haver diferenças significantes entre os diferentes tipos de terminações cervicais estudadas.

WILSON $^{95}$ (1992) mostrou estratégias e considerações sobre o assentamento de coroas totais durante a cimentação. Estas tinham como objetivo, auxiliar o escoamento do cimento do interior das coroas, levando ao menor desajuste possível 
após o procedimento. O texto traz técnicas que incluem canal de escape, alívio no troquel e controle do volume e localização do cimento a ser colocado no interior das restaurações. O comportamento das coroas durante a cimentação e as respectivas conseqüências foram discutidos.

Em 1992a, WHITE; YU ${ }^{91}$ compararam a espessura de película de vinte novos cimentos de acordo com a especificação n.8 da AMERICAN NATIONAL STANDARDS/AMERICAN DENTAL ASSOCIATION. Cada um dos materiais foi manipulado de acordo com as instruções dos fabricantes. Nove destes produziram espessura de película menores que $25 \mu \mathrm{m}$, incluindo cimentos de fosfato de zinco, policarboxilato e ionômero de vidro. Outros cinco cimentos produziram espessura entre $25 \mu \mathrm{m}$ e $40 \mu \mathrm{m}$, incluindo cimentos de fosfato de zinco, ionômero de vidro, resinoso e ionômero de vidro modificado por resina. Os demais produziram espessura de película que variava de $41,7 \mu \mathrm{m}$ a $106,7 \mu \mathrm{m}$.

Ainda em 1992b, WHITE; YU ${ }^{92}$ também investigaram o efeito da interação físicoquímica da superfície dentinária sobre a espessura dos cimentos de fosfato de zinco, policarboxilato, ionômero de vidro e resinoso. O experimento foi realizado de acordo com a especificação n.8 da AMERICAN NATIONAL STANDARDS/AMERICAN DENTAL ASSOCIATION. Para a situação controle, os agentes de cimentação foram colocados entre duas placas de vidro. Para a situação teste, foram colocados entre uma superfície dentinária plana e uma placa de vidro. Os cimentos de fosfato de zinco e ionômero de vidro demonstraram um significante decréscimo na espessura de película quando mensurada em contato com dentina, em relação à mensura entre as placas de vidro. $\mathrm{O}$ cimento de policarboxilato e o cimento resinoso não demonstraram diferença estatística significante, para a espessura de película, entre as situações testadas. 
Para examinar o efeito da força de assentamento sobre a espessura de película dos cimentos de fosfato de zinco, policarboxilato, ionômero de vidro e resinoso, WHITE; YU; KIPNIS ${ }^{93}$ (1992) utilizaram metodologia semelhante à da especificação n.8 da AMERICAN NATIONAL STANDARDS/AMERICAN DENTAL ASSOCIATION. A aplicação da força de assentamento variou, sobre o modelo experimental, com cargas de 1, 3, 5, 9, 15 e $23 \mathrm{Kg}$. Em geral, para todos os cimentos, quanto maior a força aplicada, menor a espessura de película. Esta relação manteve-se verdadeira para todos os valores de carga testados. O material menos sensível à carga foi o cimento de ionômero de vidro.

O efeito da espessura da linha de cimento e da superfície do substrato sobre a retenção de coroas totais foi estudado por JUNTAVEE; MILLSTEIN, em 1992. Cilindros de amálgama e de resina composta foram cimentados a retentores circulares de aço. O espaço destinado ao cimento, entre eles, foi padronizado em $50 \mu \mathrm{m}, 100 \mu \mathrm{m}$ e $150 \mu \mathrm{m}$. Os materiais utilizados foram cimento de fosfato de zinco, cimento resinoso e cimento de ionômero de vidro. Os valores mais altos de retenção foram obtidos para os espécimes de resina composta, utilizando cimento resinoso e com espaço para o cimento de $50 \mu \mathrm{m}$. Os valores mais baixos foram obtidos para os espécimes de resina composta, utilizando cimento de ionômero de vidro, com espaço de $150 \mu \mathrm{m}$. Em geral, o acréscimo na espessura do cimento reduziu a capacidade retentiva para todos os cimentos e superfície de substrato testados. Não houve diferença estatística significante na retenção para os espécimes com espaço para o cimento de $50 \mu \mathrm{m}$ e $100 \mu \mathrm{m}$; entretanto, houve diferença estatística significante para os espécimes com espaço de $150 \mu \mathrm{m}$ em relação aos demais.

QUALTROUGH; PIDDOCK ${ }^{70}$ (1992) revisaram os métodos de avaliação de adaptação interna e marginal de coroas, considerando os problemas associados a 
mensurações in vivo e in vitro. Técnicas como uso de sonda exploradora na margem cervical, seccionamento de dentes ou réplicas, microscópio de varredura e materiais elastoméricos foram discutidos ao longo da revisão. Os autores concluíram que devido à variedade dos métodos existentes, a comparação direta entre os dados de diferentes investigadores é com freqüência impossível. Isso se daria pelo grande número de variáveis experimentais e o pequeno número de trabalhos que fez comparações entre técnicas e revelou resultados conflitantes que indicaram a dificuldade de interpretar os dados oriundos de diferentes métodos de avaliação.

ANDERSSON; ODÉN ${ }^{3}$, em 1993, descreveram o sistema Procera AllCeram capaz de produzir i.es. cerâmicas pelo sistema CAD/CAM. Este sistema representava uma modificação no processo já existente de confecção de coroas metálicas. A descrição traz dados técnicos sobre a forma de preparo do dente, o sistema de obtenção da imagem do preparo assistido pelo computador e a confecção das coroas. Também apresentaram resultados de pesquisas envolvendo o sistema, a respeito da resistência das coroas, estabilidade de cor, desgaste e precisão de ajuste e cimentação delas. Apresentaram, ainda, evidências de biocompatibilidade do sistema Procera.

WHITE; KIPNIS ${ }^{89}$ (1993) determinaram o efeito do ajuste interno de coroas totais utilizando silicone como evidenciador de contatos internos e verificaram, também, a influência de cinco diferentes agentes de cimentação sobre o assentamento de coroas fundidas. Em laboratório, trinta e cinco pré-molares foram preparados para coroa total com o auxílio de um artefato que possibilitava padronização dos preparos. Os dentes foram moldados e seus respectivos troquéis de gesso foram encerados. As coroas foram fundidas em liga não-nobre, adaptadas a seus respectivos troquéis e receberam marcações de referência no centro de suas faces vestibular, lingual, mesial e distal. Cada coroa foi colocada sobre seu respectivo dente preparado e recebeu $49 \mathrm{~N}$ de 
carga. A adaptação marginal destas coroas, previamente ao ajuste interno, foi medida por um microscópio sob $500 \mathrm{X}$ de aumento, tendo as marcações em suas faces como referência. Então, o ajuste interno procedeu-se com silicone como evidenciador de contatos. As áreas em que o metal era mostrado através do silicone eram ajustadas com brocas esféricas. Este procedimento foi conduzido duas vezes. Em seguida, a adaptação marginal foi novamente mensurada como descrita acima. Isto feito, as coroas foram aleatoriamente cimentadas, sob carga de $49 \mathrm{~N}$, com um dos seguintes cimentos: cimento de ionômero de vidro (Ketac-Cem), cimento de policarboxilato (Durelon), cimento de fosfato de zinco (Flecks zinc phosphate), cimento resinoso de micro-partículas com BISGMA (Thin Film Cement and Tenure) e cimento resinoso de micro-partículas com BISGMA e éster fosfato (Panavia EX). Após isto, a adaptação marginal foi mais uma vez mensurada. Com a análise dos resultados observou-se que 0 assentamento melhorou após o ajuste interno e, então, piorou após a cimentação. Os melhores resultados de adaptação marginal, após a cimentação, foram obtidos nas coroas cimentadas com cimento de fosfato de zinco $(57,27 \mu \mathrm{m})$, cimento de ionômero de vidro $(57,54 \mu \mathrm{m})$ e cimento de ionômero de vidro $(67,38 \mu \mathrm{m})$. Não houve diferença estatisticamente significante entre estes grupos. As coroas cimentadas com os cimentos Panavia EX $(203,21 \mu \mathrm{m})$ e Thin Film Cement and Tenure $(160,41 \mu \mathrm{m})$ apresentaram os piores resultados de adaptação marginal.

Em 1993, SYU et al. ${ }^{83}$ investigaram a influência de diferentes tipos de términos cervicais na adaptação marginal de coroas totais fundidas. Os términos cervicais avaliados foram: ombro, ombro biselado e chanfrado. Dez coroas foram produzidas para cada tipo de término. O espaço axial e marginal destinado para o cimento foi medido com as coroas assentadas diretamente sobre seus respectivos troquéis de gesso, sem cimentação. Os resultados indicaram que os diferentes términos cervicais 
avaliados não influenciaram a adaptação marginal das coroas, já que todos produziram discrepâncias menores que $10 \mu \mathrm{m}$. Todas as coroas exibiram, também, espaço axial entre $15 \mu \mathrm{m}$ e $33 \mu \mathrm{m}$.

Através de avaliações in vivo e in vitro, KARLSSON ${ }^{47}$ (1993) estudou a adaptação interna de coroas Procera de titânio por meio de cimentação-análoga. Doze coroas (8 pré-molares, 3 incisivos e 1 canino) foram confeccionadas para o estudo. Nenhuma delas foi ajustada internamente antes da aplicação da cerâmica de recobrimento ou previamente à simulação da cimentação. Esta foi realizada com silicone fluido como cimento-análogo sobre os respectivos troquéis de gesso e dentes preparados. As linhas de cimento-análogo foram capturadas do interior das coroas com - auxílio de silicone denso. Estes espécimes de material borrachóide foram seccionados nos sentidos vestíbulo-lingual e mesio-distal e observados em um microscópio com magnificação de 50 vezes. As mensurações foram feitas no término cervical, metade da parede axial e incisal ou oclusal dos espécimes. Os valores médios encontrados para a simulação sobre os troquéis de gesso foram, nas secções vestíbulolingual e mesio-distal respectivamente, $61 \mu \mathrm{m}$ e $58 \mu \mathrm{m}$ para o término cervical, $92 \mu \mathrm{m}$ e $82 \mu \mathrm{m}$ para a metade da parede axial e $115 \mu \mathrm{m}$ e 107 para a incisal ou oclusal. Os valores médios correspondentes para a simulação sobre os dentes preparados foram, nas secções vestíbulo-lingual e mesio-distal respectivamente, $70 \mu \mathrm{m}$ e $73 \mu \mathrm{m}$ para o término cervical, $127 \mu \mathrm{m}$ e $93 \mu \mathrm{m}$ para a metade da parede axial e $161 \mu \mathrm{m}$ e 177 para a incisal ou oclusal. Houve significante diferença estatística entre os valores encontrados sobre os troquéis de gesso para as medições axiais e incisais/oclusais, quando comparados com os valores encontrados sobre os dentes preparados, para ambos os sentidos de secções. Um amplo coeficiente de variação (58\% a 70 \%) foi encontrado, independentemente da localização da medição. 
Em 1993, KAWAI; ISENBERG; LEINFELDER ${ }^{48}$ estudaram a taxa de desgaste dos cimentos resinosos com variação do tamanho de suas partículas e da área de exposição ao desgaste. Para isso, dentes molares receberam preparos cavitários quadrados em sua superfície oclusal e restaurações tipo inlay foram produzidas para cada um deles. Estas restaurações possuíam discrepância horizontal em sua interface com o dente que variava de 50 a $400 \mu \mathrm{m}$ e foram, então, cimentadas com cimentos de partículas híbridas (Cerec cement e Cerec experimental) ou de micro-partículas (Dual cement). A interface de cimento foi mantida sob atrito de cerdas metálicas com carga de $75 \mathrm{~N}$ por 400.000 ciclos e, em seguida, avaliada por microscopia de varredura e perfilometria. Sob estas condições, o cimento micro-particulado exibiu três a quatro vezes mais resistência ao desgaste do que os cimentos de partículas híbridas. Os autores salientaram que reduzir a dimensão de interface dente/restauração é um fato de suma importância clínica, tendo em vista que mesmo as discrepâncias de $50 \mu \mathrm{m}$ foram suscetíveis ao desgaste.

Ao avaliar a influência do tipo de cimento na discrepância marginal de coroas telescópicas, KERN; SCHALLER; STRUB ${ }^{51}$ (1993) valeram-se de réplicas metalizadas das margens destas coroas, observadas sob microscopia de varredura. As réplicas foram obtidas a partir de moldagens das margens, antes e após a cimentação com cimento de fosfato de zinco ou cimento de ionômero de vidro. A discrepância marginal média foi de $30 \mu \mathrm{m}$ antes da cimentação. Esta aumentou em média, após a cimentação, para $86 \mu \mathrm{m}$ nas coroas cimentadas com cimento de fosfato de zinco e para $47 \mu \mathrm{m}$ naquelas cimentadas com cimento de ionômero de vidro.

PRÖBSTER $^{67}$, ainda em 1993, avaliou o comportamento clínico de 76 coroas de In-Ceram com, em média, 35 meses de instalação. Sessenta e uma delas eram coroas unitárias e 15 eram coroas integrantes de próteses parciais fixas. Os critérios avaliados 
foram: presença de trincas nas coroas, fratura da porcelana de recobrimento, fratura da i.e. e incidência de cárie. Durante o período de acompanhamento, uma prótese parcial fixa apresentou-se fraturada, outra foi removida por comprometimento periodontal dos pilares e uma coroa unitária apresentou incidência de lesão de cárie. Para o autor as coroas In-Ceram puderam ser consideradas adequadas para dentes anteriores e posteriores.

Também em 1993, GREY; PIDDOCK; WILSON ${ }^{33}$ avaliaram o ajuste interno de coroas puras de cerâmica aluminizada (Vita $\mathrm{N}$ core), metalo-cerâmicas e In-Ceram Alumina. Para isso, simularam a cimentação destas coroas, sobre troquéis de latão que Ihes deram origem, com o evidenciador de contatos internos à base de silicone GC FitChecker. A avaliação deu-se da seguinte forma: o conjunto de coroa e troquel metálico fora pesado por uma balança eletrônica antes e após a simulação; a diferença das medidas revelava o peso do material borrachóide, que tinha sua área calculada. O valor médio encontrado para as coroas de Vita $\mathrm{N}$ core foi de $154 \mu \mathrm{m}( \pm 37 \mu \mathrm{m})$, para as coroas In-Ceram Alumina, de $123 \mu \mathrm{m}( \pm 30 \mu \mathrm{m})$ e para as coroas metalo-cerâmicas, de $95 \mu \mathrm{m}( \pm 23 \mu \mathrm{m})$.

STRUTZ et al. ${ }^{81}$ (1994) investigaram a interação físico-química das superfícies metálicas, sobre a espessura dos cimentos de fosfato de zinco, policarboxilato, ionômero de vidro, resinoso e ionômero de vidro modificado por resina. Fazendo parte dos grupos experimentais, estes cimentos foram colocados entre um disco de vidro e um disco de liga metálica, recebendo $15 \mathrm{~kg}$ de carga. As ligas testadas foram: liga de ouro tipo III, liga com alto volume de paládio e liga básica. Como controle, os mesmos agentes de cimentação foram testados de acordo com a especificação n.8 da AMERICAN NATIONAL STANDARDS/AMERICAN DENTAL ASSOCIATION. O tipo de cimento e a superfície do substrato tiveram significante efeito sobre a espessura da 
película. Entretanto, o tipo de cimento teve maior significância e magnitude que a superfície do substrato. Embora a liga com alto volume de paládio tenha promovido espessura de película significantemente menor que as demais superfícies, a diferença entre elas foi pequena. $\mathrm{O}$ cimento de ionômero de vidro produziu a mais fina película dentre todos os outros cimentos $(13,5 \mu \mathrm{m})$.

Em 1994, SCHERRER et al. ${ }^{75}$ determinaram a resistência à fratura de placas de vidro cerâmico, cimentadas sobre blocos de resina composta, em função da espessura da película de dois tipos de cimentos. Cento e trinta placas cerâmicas foram divididas em dois grupos iguais, que receberam cimentação com cimento de fosfato de zinco ou cimento resinoso (Dicor MGC). O primeiro dos agentes de cimentação foi testado com espessuras de película de $33 \mu \mathrm{m}$ e $128 \mu \mathrm{m}$. O segundo, com espessuras de $26 \mu \mathrm{m}, 78$ $\mu \mathrm{m}, 130 \mu \mathrm{m}, 192 \mu \mathrm{m}$ e $297 \mu \mathrm{m}$. Os resultados mostraram que para o cimento de fosfato de zinco, a resistência à fratura das placas, para as espessura de película de $33 \mu \mathrm{m}$ e $128 \mu \mathrm{m}$, não foi estatisticamente significante. Para o cimento resinoso, houve uma leve diferença estatística significante apenas entre os espécimes de espessura de cimento com $26 \mu \mathrm{m}$ e $297 \mu \mathrm{m}$.

PERA et al. ${ }^{63}$ (1994) avaliaram in vitro a discrepância marginal do sistema InCeram com três diferentes terminações cervicais de preparo dental e examinaram a estabilidade dimensional do sistema durante as queimas da porcelana de recobrimento. Os términos cervicais avaliados foram: chanfrado, ombro em $50^{\circ}$ e ombro em $90^{\circ}$. Nove coroas foram confeccionadas para cada terminação sendo 3 em incisivos centrais, 3 em caninos e 3 em primeiros pré-molares. As coroas foram cimentadas sobre seus respectivos dentes preparados com cimento de ionômero de vidro, sob pressão manual. A discrepância marginal média antes e após a cimentação, respectivamente, para a terminação em chanfrado foi de 9,44 $\mu \mathrm{m}$ e 21,67 $\mu \mathrm{m}$, para a terminação em ombro em 
$50^{\circ}$ foi de $7,5 \mu \mathrm{m}$ e $23,75 \mu \mathrm{m}$ e para a terminação em ombro em $90^{\circ}$ foi de $13,61 \mu \mathrm{m}$ e 27,5 $\mu \mathrm{m}$. A estabilidade dimensional das i.es. foi mantida durante as queimas da porcelana de recobrimento, independentemente do tipo de terminação cervical avaliada. WILSON $^{96}$ (1994) investigou o efeito sobre o assentamento de coroas artificiais com o aumento progressivo do espaço para a película de cimento. Para o estudo, foram confeccionados 6 troquéis metálicos que, quando aposicionados sob uma mesma coroa, apresentavam espaço interno para o agente de cimentação que variava de $0 \mu \mathrm{m}$ a $50 \mu \mathrm{m}$, em intervalos de $10 \mu \mathrm{m}$. Sob carga de $25 \mathrm{~N}$, a discrepância marginal entre as coroas e o término do preparo dos troquéis, antes da cimentação, foi medida e tomada como zero (medida inicial). A discrepância no assentamento das coroas, após cimentação com cimento de fosfato de zinco, sob carga de $25 \mathrm{~N}$, variou de $368 \mu \mathrm{m}$ (0 $\mu \mathrm{m}$ de espaço interno) a $29 \mu \mathrm{m}$ (50 $\mu \mathrm{m}$ de espaço interno). O autor concluiu que a existência de espaço axial facilita o escoamento do cimento até a margem da restauração, enquanto acomoda a camada mais fina possível deste.

Também no ano de 1994, WU; WILSON ${ }^{100}$ investigaram o volume de espaço necessário para o adequado assentamento de coroas cimentadas com cimento resinoso. Oito troquéis de aço foram confeccionados em um torno mecânico. Uma coroa de latão foi torneada de forma que se adaptasse sem espaço interno algum em relação a um dos troquéis $(0 \mu \mathrm{m})$. Os demais troquéis tinham redução axial e oclusal em relação ao primeiro da seguinte forma: $10 \mu \mathrm{m}, 20 \mu \mathrm{m}, 30 \mu \mathrm{m}, 40 \mu \mathrm{m}, 50 \mu \mathrm{m}, 60 \mu \mathrm{m}$ e $80 \mu \mathrm{m}$, respectivamente. Os troquéis foram assentados sobre a coroa com $25 \mathrm{~N}$ de carga. Os agentes de cimentação utilizados foram o cimento de fosfato de zinco (servindo como comparação) e dois tipos de cimentos resinosos (Panavia EX e C \& B Metabond). A discrepância vertical de assentamento (DVA) foi medida por diferença de voltagem em um aparato específico. O cimento de fosfato de fosfato de zinco produziu DVA para os 
espécimes com $0 \mu \mathrm{m}, 20 \mu \mathrm{m}, 40 \mu \mathrm{m}$ e $80 \mu \mathrm{m}$ de espaço para o cimento de, respectivamente, $364 \mu \mathrm{m}, 168 \mu \mathrm{m}, 46 \mu \mathrm{m}$ e $31 \mu \mathrm{m}$. O cimento Panavia EX, para as mesmas variações de espaço interno, produziu DVA respectivamente de $134 \mu \mathrm{m}, 31$ $\mu \mathrm{m}, 22 \mu \mathrm{m}$ e $23 \mu \mathrm{m}$. O cimento C \& B Metabond produziu DVA intermediária entre os dois outros cimentos. Os autores concluíram que volumes aumentados de espaço interno resultam em decréscimo na DVA dos cimentos estudados.

McINTYRE et al. ${ }^{56}$ (1994) estudaram a relação entre espessura de cimento de policarboxilato e resistência ao cisalhamento e à tração. Para isso, utilizaram dentes molares, com superfície oclusal desgastada perpendicular ao seu longo eixo, até a exposição da dentina, deixando-a plana. Sobre ela cimentaram discos fundidos em liga áurica. A espessura do cimento foi controlada e variava entre $10 \mu \mathrm{m}$ e $150 \mu \mathrm{m}$. Os resultados mostraram um aumento tanto na resistência ao cisalhamento quanto na resistência à tração, com o aumento na espessura de cimento de policarboxilato. A resistência ao cisalhamento foi maior que à tração. Quando os espécimes testados foram observados sob microscopia, observou-se um maior número de microporosidades naqueles com espessura de película de cimento inferior a $50 \mu \mathrm{m}$ do que em espécimes com espessura superior a esta.

Em 1995, PERSSON; ANDERSSON; BERGMAN ${ }^{64}$ avaliaram a precisão do dispositivo de leitura do escandidor do sistema Procera. A avaliação foi feita comparando-se as dimensões obtidas a partir da leitura de um bloco retangular de metal pré-fabricado pelo dispositivo de leitura do sistema, com as dimensões já conhecidas do objeto. Os resultados demonstraram alta precisão para o dispositivo de leitura.

No ano de 1996, PRÖBSTER ${ }^{68}$ conduziu um estudo clínico longitudinal por 56 meses, de 95 coroas do sistema In-Ceram alumina. Elas foram construídas a partir de 
preparos dentais em 18 pacientes e cimentadas com cimento de fosfato de zinco (dentes posteriores) e com cimento de ionômero de vidro (dentes anteriores). Os pacientes eram chamados para exame clínico ao menos uma vez ao ano e os critérios avaliados no exame eram: presença de trincas nas coroas, fratura da porcelana de recobrimento, fratura da i.e., infiltração nas margens, cáries e desgaste oclusal ou abrasão. A cobertura de uma das coroa posterior apresentou fratura e quatro coroas apresentaram cárie em suas margens. As demais restaurações não apresentaram qualquer sinal, dentre os apontados nos requisitos acima descritos, fazendo com que os autores concluíssem que o sistema In-Ceram alumina estaria indicado para dentes anteriores e posteriores.

O efeito de duas diferentes configurações marginais (chanfrado em $120^{\circ} \mathrm{e}$ ombro em $90^{\circ}$ ) na linha de cimento de i.es. In-Ceram e o efeito da adição de porcelana de recobrimento sobre estas i.es. foram estudados por SHEARER; GOUGH; SETCHELL ${ }^{78}$, em 1996. Um incisivo central superior foi preparado para coroa total. Dois troquéis-padrão metálicos em liga de níquel-cromo foram confeccionados a partir daquele incisivo central, cada um com uma das configurações marginais estudadas. Cada troquel-padrão deu origem a 10 troquéis de prata fabricados por eletrodeposição. Cinco i.es. de In-Ceram foram feitas para cada troquel-padrão. Outras dez i.es. do mesmo sistema foram feitas para cada troquel de prata. Todas elas receberam a adição de porcelana de recobrimento. As coroas fabricadas sobre os troquéis de prata foram cimentadas sobre os mesmos com cimento de ionômero de vidro e o conjunto seccionado no sentido vestíbulo-lingual. Simulou-se a cimentação das coroas sobre os troquéis-padrão com um elastômero à base de polivinil siloxana. A simulação foi feita antes e após a aplicação da porcelana de recobrimento. Metade dos espécimes de cimento-análogo foi seccionada no sentido vestíbulo-lingual e a outra metade, no mesiodistal, com espessuras medidas sob magnificação de 20 vezes. As mensurações foram 
feitas no término cervical, metade da parede axial e incisal de cada coroa ou espécime de cimento-análogo. Foram encontrados valores médios de linha de cimento mais altos para os espécimes de cimento-análogo (28,6 $\mu \mathrm{m}$ para ombro e $13,4 \mu \mathrm{m}$ para chanfrado) do que para as coroas cimentadas sobre os troquéis de prata $(8,3 \mu \mathrm{m}$ para ombro e 9,8 $\mu \mathrm{m}$ para chanfrado). Não houve diferença estatística significante entre os valores de linha de cimento-análogo para as secções vestíbulo-lingual e mesio-distal, nem para os valores encontrados antes e após a aplicação da porcelana de recobrimento, nem mesmo para as diferentes configurações marginais estudadas. $\mathrm{O}$ valor médio da linha de cimento das coroas avaliadas foi igual a $60,9 \mu \mathrm{m}$ e uma espessura média de $15 \mu \mathrm{m}$ foi encontrada próxima às margens.

Em 1996, TAN; IBBETSON ${ }^{85}$ propuseram-se investigar a relação entre a discrepância vertical de assentamento de coroas totais e o volume de agente de cimentação utilizado. Por eletrodeposição, uma coroa de cobre foi confeccionada sobre um troquel-padrão metálico em forma de um dente molar, que havia sido previamente coberto por quatro camadas de espaçador. Três volumes experimentais de cimento de fosfato de zinco foram utilizados neste estudo. O interior da coroa foi completamente preenchido pelo cimento, metade preenchido, ou o cimento foi apenas pincelado nas paredes internas da mesma. Durante as seqüentes cimentações experimentais da mesma coroa, que foi repetidamente utilizada, ambas cargas estática e dinâmica foram aplicadas. A carga estática foi mantida por um peso de $5 \mathrm{Kg}$ e a carga dinâmica induzida por um condensador de amálgama. A discrepância vertical foi medida por um multímetro digital que obtinha a posição vertical da coroa antes e após o experimento. Os resultados obtidos nas situações em que o cimento ocupava metade do volume interno da coroa ou pincelado em suas paredes internas foram, respectivamente, $53,2 \%$ e $69,6 \%$ melhores do que quando preenchia todo o interior da coroa. Os autores 
atribuíram estes achados a um dos seguintes fatores: o cimento ficaria retido sobre a superfície oclusal do troquel-padrão à medida que as vias de escape pelas paredes axiais se fechavam; um aumento na pressão hidrostática resultaria em filtragem do cimento ao longo dos estreitos espaços entre troquel-padrão e coroa, diminuindo o escape do mesmo ou grandes volumes demorariam mais tempo para escoar, sofrendo maior influência do aumento de sua viscosidade com o passar do tempo.

Ainda em 1996, WILSON ${ }^{97}$ avaliou a influência dos canais de escape e da carga de cimentação em coroas totais, sobre o assentamento das mesmas. Uma coroa fundida em liga áurica foi cimentada repetidamente sobre um troquel-padrão metálico. Esta possuía uma perfuração no centro de sua superfície oclusal, que podia ser obliterada quando desejado. Dois diferentes cimentos (fosfato de zinco e ionômero de vidro) foram utilizados nas cimentações, que ocorreram sob 2,5 N, 12,5 N e $25 \mathrm{~N}$ de força. As cimentações com 2,5 N de força produziram elevações médias nas coroas de $696 \mu \mathrm{m}$ a $953 \mu \mathrm{m}$. Sob $12,5 \mathrm{~N}$ e $25 \mathrm{~N}$, o cimento de fosfato de zinco produziu, respectivamente, espessura de $193 \mu \mathrm{m}$ e $84 \mu \mathrm{m}$ nas coroas sem canal de escape e de $84 \mu \mathrm{m}$ e $19 \mu \mathrm{m}$ naquelas com canal. O cimento de ionômero de vidro produziu, sob 12,5 $\mathrm{N}$ e $25 \mathrm{~N}$, respectivamente, espessura de $45 \mu \mathrm{m}$ e $15 \mu \mathrm{m}$ nas coroas sem canal de escape e de $17 \mu \mathrm{m}$ e $11 \mu \mathrm{m}$ naquelas com canal.

SULAIMAN et al. ${ }^{82}$ (1997) compararam a discrepância marginal de três sistemas cerâmicos (Procera AllCeram, In-Ceram e IPS Empress) após a confecção das i.es., após a aplicação da porcelana de recobrimento e após o glazeamento. Dez coroas de cada sistema foram confeccionadas e a discrepância marginal avaliada com estas assentadas sem agente de cimentação, sobre um mesmo troquel-padrão metálico, sob 1,36 $\mathrm{Kg}$ de força. As medições foram feitas em um microscópio digital com magnificação de 225 vezes nos 3 estágios descritos acima. Os resultados apontaram 
não haver diferença estatística significante entre os três estágios de confecção das coroas, independente do sistema avaliado. A discrepância marginal para o grupo InCeram foi de $160,66 \mu \mathrm{m}$, para o grupo Procera, de $82,88 \mu \mathrm{m}$ e para o sistema IPS Empress, de 62,77 $\mu \mathrm{m}$.

CARTER; WILSON ${ }^{12}$, também em 1997, fizeram uma revisão da literatura a respeito dos espaçadores de troquéis e seus efeitos sobre o assentamento e a retenção de coroas totais. Eles encontraram que os espaçadores trazem uma série de benefícios ao assentamento das coroas. Encontraram, também, alguns trabalhos que apontaram a tendência destes materiais em formar uma camada irregular de espaço, produzindo fundições com variação no espaço interno para o cimento. Quanto ao efeito sobre a retenção das coroas, encontraram alguns conflitos nos resultados pesquisados. Relataram não terem encontrado protocolos confiáveis de comparação entre os estudos avaliados, sugerindo mais pesquisas sobre a relação entre retenção e os espaçadores.

Ao avaliar a influência da espessura de cimento na resistência à tração de cimentos resinosos, CHANA et al. ${ }^{14}$ (1997) utilizaram superfícies planas de níquelcromo interpostas por duas diferentes marcas comerciais de cimento (Panavia Ex e Panavia 21). A espessura de cimento entre as superfícies foi controlada e tinha os seguintes valores: $20 \mu \mathrm{m}, 50 \mu \mathrm{m}, 100 \mu \mathrm{m}, 150 \mu \mathrm{m}, 210 \mu \mathrm{m}, 250 \mu \mathrm{m}$ e $310 \mu \mathrm{m}$. Os espécimes foram tracionados por uma máquina de ensaios universal e os resultados indicaram que à medida que a espessura de cimento aumentava, a resistência do cimento diminuía. O cimento Panavia 21 teve significantemente maior resistência à tração que o cimento Panavia Ex, para todas as espessuras de cimento testadas.

Através de um estudo laboratorial, MAY et al. ${ }^{55}$ (1998), propuseram-se a mensurar a abertura marginal e a precisão na adaptação de coroas totais confeccionadas pelo sistema Procera AllCeram. Cinco coroas totais de pré-molares e molares foram 
confeccionadas a partir de troqueis de gesso. Simulou-se a cimentação destas coroas sobre seus respectivos troqueis, utilizando-se silicone de adição de consistência fluida. Através de laservideografia, o espaço ocupado pelo material que simulou a cimentação foi medido nas margens, paredes axiais, pontas de cúspides e centro da face oclusal. A abertura marginal encontrada para os pré-molares e molares, respectivamente, foi de $56 \mu \mathrm{m} \pm 21 \mu \mathrm{m}$ e de $63 \mu \mathrm{m} \pm 13 \mu \mathrm{m}$. A média do desajuste interno das coroas, representando segundo os autores, sua precisão na adaptação, foi igual a $52 \mu \mathrm{m} \pm 19$ $\mu \mathrm{m}$ para os pré-molares e $63 \mu \mathrm{m} \pm 20 \mu \mathrm{m}$ para os molares. Os autores concluíram que 0 sistema Procera AllCeram produziu coroas para pré-molares e molares com adaptação marginal e ajuste interno clinicamente aceitáveis.

Ainda em 1998, NEIVA et al. ${ }^{58}$ compararam a resistência à fratura e a espessura de linha de cimento de três sistemas cerâmicos: IPS Empress, In-Ceram e Procera AllCeram. Para determinar a resistência à fratura, utilizaram 30 troquéis de resina com módulo de elasticidade semelhante ao da dentina, obtidos a partir de um troquel padrão. Foram confeccionadas dez coroas para cada sistema, que foram cimentadas sobre seus respectivos troquéis com cimento resinoso Panavia 21. Em seguida, submetidas à pressão axial sobre a superfície oclusal, com o auxílio de uma máquina universal de testes Instron. Para determinar a espessura da linha de cimento sob as coroas, apenas um espécime de cada sistema foi levado ao microscópio óptico. As áreas avaliadas foram: margem, parede axial (a $2 \mathrm{~mm}$ de distância da margem), ponta de cúspide vestibular, centro da superfície oclusal e ponta de cúspide lingual. Os resultados não mostraram diferenças estatisticamente significantes de resistência à fratura entre os três sistemas pesquisados, quando cimentados com cimento resinoso Panavia 21. O sistema IPS Empress apresentou a maior média de resistência à fratura $(222,45 \mathrm{Kg})$, enquanto o sistema Procera AllCeram, a menor $(194,20 \mathrm{Kg})$. O sistema In-Ceram 
apresentou a média intermediária dentre os três grupos: $218,80 \mathrm{Kg}$. Quanto à espessura da linha de cimento, o sistema Procera AllCeram foi o que demonstrou os maiores valores, especialmente na margem $(225 \mu \mathrm{m})$ e na parede axial $(105 \mu \mathrm{m})$.

Através de um estudo retrospectivo, PILO; CARDASH ${ }^{66}$ (1998) mensuraram a espessura da película de cimento abaixo de coroas totais em função durante longo período, em dentes extraídos por razões periodontais. Todas as coroas estudadas eram metálicas com cobertura cerâmica ou de resina, haviam sido cimentadas com cimento de fosfato de zinco e estiveram em função por ao menos 10 anos. Nenhuma delas apresentava recidiva de cárie em suas margens ou fazia parte de próteses parciais fixas. Noventa e sete dentes (48 dentes anteriores, 22 pré-molares e 27 molares) com suas coroas aposicionadas foram incluídos em poliéster transparente e seccionados duas vezes no sentido vestíbulo-lingual. Cada uma das secções situava-se aproximadamente a $0,75 \mathrm{~mm}$ de cada um dos lados do centro dos dentes. A espessura da linha de cimento foi medida em locais predeterminados nas paredes axiais e oclusal/incisal: nos pontos respectivos a um terço e dois terços da altura das paredes axiais lingual e vestibular; e no ponto mais alto da extremidade incisal, nos dentes anteriores, ou no ponto mais alto das cúspides vestibular e lingual e sulco central nos molares e pré-molares. A média da espessura encontrada para as paredes axiais foi de $116 \mu \mathrm{m}$ (vestibular) e $109 \mu \mathrm{m}$ (lingual). Para a superfície oclusal/incisal a espessura foi de $302 \mu \mathrm{m}$. Os autores ressaltaram que pela falta de padronização do preparo dos dentes, técnica de cimentação e volume de alívio interno das coroas, estes dados encontrados deveriam ser observados com cautela.

O Comitê Ad Hoc para Pesquisa em Prótese Fixa da Academia Americana de Prótese fixa foi encarregado de disseminar o conhecimento específico da especialidade, através de revisões anuais da literatura. Em 1998, ROSENSTIEL; LAND; CRISPIN ${ }^{74}$ 
revisaram, a pedido do Comitê, os agentes de cimentação para restaurações indiretas. As propriedades biológicas e mecânicas dos cimentos disponíveis até aquele momento foram descritas e discutidas. Um guia para seleção dos agentes de cimentação também foi apresentado.

WISKOTT; BELSER; SCHERRER ${ }^{99}$, em 1999, através de um trabalho laboratorial, estudaram o efeito da espessura da linha de cimento e da textura da superfície interna de coroas totais, na resistência a forças cíclicas laterais. Coroas metálicas torneadas foram cimentadas sobre troqueis, também torneados, com cimento de óxido de zinco eugenol, cimento de fosfato de zinco, cimento de ionômero de vidro e cimento resinoso. Estas coroas foram fabricadas com espaço interno pré-definido em 20 $\mu \mathrm{m}, 50 \mu \mathrm{m}, 100 \mu \mathrm{m}, 200 \mu \mathrm{m}$ e $500 \mu \mathrm{m}$. Três diferentes graus de textura interna foram testados: polido com lixa de granulação 4.000, texturizado com lixa de granulação 1.000 e jateado com óxido de alumínio. Os resultados mostraram que a resistência à carga lateral aumentou com o decréscimo na espessura da linha de cimento e aumento na irregularidade da textura superficial das coroas.

Ainda em 1999, BESCHNIDT; STRUB ${ }^{7}$ avaliaram a discrepância marginal de cinco diferentes sistemas de coroas cerâmicas antes e após sua cimentação e após testes de fadiga por carga cíclica e termo-ciclagem. Estas coroas foram cimentadas de forma adesiva sobre dentes naturais. Os resultados foram comparados com dados obtidos em situações semelhantes em coroas metalo-cerâmicas "colar-less" cimentadas com cimento de fosfato de zinco. Sessenta incisivos superiores foram preparados para coroa total, moldados e obtidos os respectivos troquéis de gesso. Estes foram divididos em seis grupos de 10 espécimes: metalo-cerâmica "colar-less" (MC), In-Ceram convencional (IC), Empress com pigmentação extrínseca (EP), Empress com cobertura por estratifacação (EE), Celay com matriz feldspática (CF) e Celay com matriz In-Ceram (CI). As coroas foram confeccionadas e réplicas de resina epóxica, confeccionadas a 
partir de cópias com silicone de adição, foram obtidas em cada uma dos seguintes momentos: mantidas sobre os respectivos dentes preparados antes da cimentação, cimentadas sobre os respectivos dentes e após os testes de termo-ciclagem e fadiga cíclica. A discrepância marginal das réplicas foi analisada sob aumento de 400 vezes e um programa de computador efetuou de 2500 a 3000 medições ao redor de cada espécime. Os valores médios antes e após a cimentação foram, respectivamente, para MC, $64 \mu \mathrm{m}$ e $87 \mu \mathrm{m}$, para IC, $60 \mu \mathrm{m}$ e $82 \mu \mathrm{m}$, para EP, $47 \mu \mathrm{m}$ e $63 \mu \mathrm{m}$, para EE, $62 \mu \mathrm{m}$ e $76 \mu \mathrm{m}$, para CF, $99 \mu \mathrm{m}$ e $117 \mu \mathrm{m}$ e para $\mathrm{Cl}, 78 \mu \mathrm{m}$ e $91 \mu \mathrm{m}$. Houve um aumento estatisticamente significante na discrepância marginal causada pela cimentação em todos os grupos. A ciclagem térmica e a carga cíclica não afetaram a discrepância marginal. Antes da cimentação não havia diferença estatística significante entre os grupos de coroas cerâmicas e o grupo MC. Após a cimentação, o grupo EP apresentou discrepância marginal estatisticamente menor e o grupo CF, estatisticamente maior, quando comparados ao grupo MC. $\mathrm{O}$ experimento demonstrou que a discrepância marginal obtida após a cimentação adesiva pode não diferir daquela obtida após cimentação convencional.

DIAZ-ARNOLD; VARGAS; HASELTON ${ }^{21}$, em 1999, discorreram sobre os cimentos utilizados até aquela data para cimentação de restaurações protéticas. Abordaram a composição e as características dos cimentos de fosfato de zinco, policarboxilato, ionômero de vidro, resinoso e ionômero de vidro modificado por resina.

GIORDANO I ${ }^{30}$, em 2000, descreveu alguns sistemas cerâmicos para confecção de coroas totais, destacando as propriedades físicas do sistema In-Ceram, baseado na técnica de aplicação sobre o troquel (slip casting), com subseqüente infiltração pelo vidro. Segundo ele, as i.es. fabricadas com alumina, apresentariam resistência flexural entre $450 \mathrm{Mpa}$ e $600 \mathrm{Mpa}$, sendo indicadas em elementos isolados anteriores e 
posteriores e próteses parciais fixas anteriores de 3 elementos. O sistema In-Ceram Spinell diferiria do primeiro pela alta transluscência e menor resistência flexural (350 Mpa), sendo indicado para inlays e onlays. Ainda segundo o autor, um terceiro sistema, o In-Ceram Zirconia, apresentaria resistência flexural acima de 750 Mpa. Devido à sua baixa transluscidez, estaria indicado para coroas em dentes posteriores. A recomendação para o desgaste das paredes dos preparos, de acordo com o autor, seria de $1,5 \mathrm{~mm}$ a 2,0 $\mathrm{mm}$ nas paredes axiais e oclusais.

Em 2000, BOENING et al. ${ }^{9}$ avaliaram clinicamente o espaço interno oclusal e marginal de 80 coroas Procera AllCeram, em dentes anteriores e posteriores, através da cimentação simulada com elastômero (silicone de adição). Após a simulação da cimentação, a película de elastômero era removida do interior da coroa com o auxílio de um silicone de consistência pesada. Desta mesma forma, era mantida estabilizada e o bloco de material elastomérico era seccionado nos sentidos vestíbulo-lingual e mesiodistal. Sob um microscópio óptico, seis medições marginais (duas na face vestibular, duas na face lingual e uma em cada proximal) e duas medições oclusais foram feitas para os dentes anteriores. Os dentes posteriores tiveram oito medições marginais (duas em cada face axial) e quatro oclusais. Quando existia mais de um ponto de medição em uma mesma face, estes se encontravam a $2 \mathrm{~mm}$ de distância entre eles. Como resultados, os autores obtiveram que a média dos valores médios de desajuste marginal estava entre $80 \mu \mathrm{m}$ e $95 \mu \mathrm{m}$ nos dentes anteriores e entre $90 \mu \mathrm{m}$ e $145 \mu \mathrm{m}$ nos posteriores. A média dos valores extremos de desajuste marginal era de $80 \mu \mathrm{m}$ a 180 $\mu \mathrm{m}$ e de $115 \mu \mathrm{m}$ a $245 \mu \mathrm{m}$ para os dentes anteriores e posteriores, respectivamente.

USHIWATA et al. ${ }^{87}$ (2000) avaliaram a técnica de ajuste interno coroas fundidas em liga básica com evidenciador de contatos Arti-Spot. Coroas fundidas com e sem 
alívio interno tiveram melhora significativa em seu assentamento $(52,2 \%)$, sobre seus respectivos troquéis de gesso, após ajuste interno.

Em 2001, ÖDMAN; ANDERSSON ${ }^{59}$ apresentaram os resultados de um estudo prospectivo multicêntrico de acompanhamento de coroas Procera AllCeram. Oitenta e sete coroas instaladas por doze profissionais em cinqüenta pacientes, entre os anos 1989 e 1995, foram acompanhadas clinicamente por 5 a 10,5 anos. Setenta e nove destas coroas foram cimentadas com cimento de fosfato de zinco e oito com cimento de ionômero de vidro. A avaliação da integridade marginal e da estética seguiu o sistema de avaliação qualitativa da Associação Odontológica da Califórnia. Na avaliação da integridade marginal, $92 \%$ das coroas foram consideradas excelentes ou aceitáveis e duas superfícies cariadas foram registradas. Onze coroas se soltaram e segundo os autores isso teria acontecido por erro na forma do preparo. Foi também evidenciado uma maior freqüência de sangramento à sondagem em dentes com coroas Procera AllCeram (39\%) do que em dentes naturais adjacentes $(27 \%)$.

AYUB $^{5}$ (2002) avaliou o espaço interno de i.es. para coroas metalo-cerâmicas e cerâmicas dos sistemas Empress 2, In-Ceram Alumina e Procera AllCeram. Para isso, mensurou a espessura de película de um elastômero fluido (Xantopren), obtida pela técnica do cimento-análogo, sob i.es. confeccionadas sobre um preparo de dente prémolar. A análise dos resultados mostrou que houve grande variabilidade da espessura de película nas diferentes regiões medidas das i.es. Observou, ainda, que as i.es. Procera AllCeram apresentaram película estatisticamente significante maior do que as demais, além de observar evidências de assentamento oblíquo na maioria das i.es.

Para comparar a resistência flexural entre os sistemas In-Ceram Zirconia e InCeram Alumina, CHONG et al. ${ }^{15}$, em 2002, fabricaram dez i.es. de cada sistema, de acordo com as recomendações do fabricante. Outras dez i.es. para faceta laminada, com aplicação de porcelana de cobertura (Vitadur $\alpha$ ) também foram confeccionadas 
para os dois sistemas. Uma máquina de carga foi utilizada para o teste de resistência flexural de três pontos. A resistência do sistema In-Ceram Zirconia (513 Mpa e 64 Mpa, para i.es. de coroas e facetas laminadas, respectivamente) foi significativamente maior que a encontrada para o sistema In-Ceram Alumina (362 Mpa e 47 Mpa, para i.es. de coroas e facetas laminadas, respectivamente). Os autores acreditaram que as propriedades de resistência e dureza do zircônio tiveram influência positiva nas propriedades do In-Ceram Zirconia.

KEYS $^{52}$ (2002) apresentou uma técnica de verificação de ajuste interno de coroas totalmente cerâmicas. Sugeriu que um evidenciador de superfície em forma de pasta sem pigmentos e de fácil remoção, fosse acrescido de um spray de substância para verificação de contatos oclusais. A sugestão se faria válida pela facilidade de verificação de áreas de contato interno pelo alto contraste com a coroa, presa rápida e facilidade de remoção. Sugeriu que a superfície interna da coroa seja seca por jato de ar e partes iguais das pastas fossem manipuladas, juntamente com um leve jato de aerossol verificador de contatos oclusais. A mistura deveria ser aplicada à superfície interna da coroa e levada em posição sobre o dente. Após sua presa, a coroa deveria ser removida e o ajuste verificado.

Em 2002, de la MACORRA; PRADÍES ${ }^{53}$ revisaram a literatura para avaliar os requisitos funcionais dos cimentos disponíveis no mercado até aquele ano. Discutiram a respeito de aspectos como película de cimento, selamento da margem das restaurações, desgaste, adesão e solubilidade. Puderam concluir que não existia um cimento que pudesse ser considerado "ideal" até aquele momento.

Através de análise por elemento finito, FISCHER; WEBER; MARX ${ }^{25}$ (2003) predisseram a probabilidade de falha e a capacidade de carga de próteses parciais fixas cerâmicas em dentes posteriores dos sistemas Empress, Empress 2, In-Ceram Alumina e In-Ceram Zirconia. Na simulação não foi considerada a película de cimento abaixo 
das coroas. Quando considerado um correto desenho das i.es., a probabilidade de falha do sistema In-Ceram Zirconia foi perto de 0, para um período de 10 anos; o menor dentre os avaliados.

Em 2003, OLSSON et al. ${ }^{61}$ avaliaram os resultados de 18 próteses parciais fixas In-Ceram Alumina de 2 ou 3 elementos instaladas nas regiões posteriores e anterior, cimentadas com cimento de fosfato de zinco. Estas estiveram em função por, em média, 76 meses. Durante o período de observação, três destas próteses instaladas na região posterior fraturaram em função. Uma outra prótese descimentou após 73 meses. Os autores apontaram o sistema In-Ceram Alumina como uma alternativa viável para próteses parciais fixas.

$\operatorname{BLATZ}^{8}$ (2004) discorreu sobre cimentação convencional e adesiva de coroas de óxido de zircônio. Comentou sobre a possibilidade de cimentação destas coroas com cimentos de fosfato de zinco e ionômero de vidro. Porém, sinalizou a preferência de alguns pesquisadores em indicar cimentação adesiva para as mesmas, justificando a opção pelo aumento da retenção e da resistência das coroas, bem como diminuição da infiltração marginal.

QUINTAS; OLIVEIRA; BOTTINO ${ }^{71}$ (2004) avaliaram o efeito de diferentes desenhos de término cervical, sistemas cerâmicos e agentes de cimentação, no desajuste cervical após a cimentação de i.es. cerâmicas. Dois troquéis de aço foram torneados com dimensões semelhantes a um preparo para coroa total em um molar inferior. Um deles com terminação cervical em chanfrado e o outro, em ombro arredondado. Ambos os troquéis foram moldados, dando origem a 180 troquéis de gesso (noventa de cada término cervical). Sobre estes, foram construídas i.es. dos sistemas Empress 2, In-Ceram Alumina e Procera AllCeram (trinta i.es. de cada sistema, para cada tipo de término cervical). As coroas foram cimentadas sobre o mesmo troquel de aço com os cimentos de fosfato de zinco, ionômero de vidro e 
resinoso. Esta gama de variáveis deu origem a 18 grupos experimentais. A mensuração do desajuste vertical em apenas uma das faces deu-se pela diferença entre dois pontos, um na coroa e outro no troquel de aço, antes e após a cimentação. Os resultados mostraram que o tipo de agente de cimentação não foi significante quando considerado isoladamente. O tipo de término cervical também não foi significante para a grande maioria dos grupos. Entretanto, as i.es. do sistema Procera AllCeram apresentaram os menores valores médios de desajuste vertical após cimentação (19 $\mu \mathrm{m})$, quando comparadas àquelas dos sistemas Empress $2(42 \mu \mathrm{m})$ e In-Ceram Alumina (60 $\mu \mathrm{m})$.

Ainda em 2004, CHAN et al. ${ }^{13}$ avaliaram o desajuste vertical decorrente da cimentação com fosfato de zinco e a retenção de coroas totais. Quarenta e seis troquéis metálicos, com grau de convergência que variava de $0^{\circ}$ a $70^{\circ}$, receberam coroas metálicas com sulco de escape oclusal. O desajuste vertical foi mensurado através de marcações coincidentes, uma na coroa e outra no troquel, em duas de suas faces, distantes em $180^{\circ}$. A distância entre os pontos foi mensurada antes e após a cimentação das coroas. A diferença entre as medidas inicial e final representou a variação de desajuste vertical decorrente da cimentação. Isto feito, as coroas foram tracionadas por uma máquina de ensaios universal com velocidade de $0,5 \mathrm{~mm} / \mathrm{min}$. Frente às mensurações, pôde ser observado o assentamento oblíquo das coroas. Os resultados mostraram que quanto maior o grau de convergência, maior foi o desajuste vertical das coroas. A análise de correlação de Pearson revelou que a partir de $12^{\circ}$ de convergência das paredes, existiu um decréscimo correspondente na retenção. 
3. PROPOSIÇÃO 


\section{PROPOSIÇÃO}

Através da constituição de 3 grupos, sendo:

Grupo MC: infra-estruturas metálicas para coroas metalo-cerâmicas;

Grupo IZ: infra-estruturas de zircônio do sistema In-Ceram Zirconia;

Grupo PZ: infra-estruturas de zircônio do sistema Procera AllZirkon.

Propõe-se, através da simulação da cimentação pela técnica do cimentoanálogo, avaliar:

I. a influência do ajuste interno na adaptação;

II. o desajuste vertical após a simulação da cimentação;

III. a espessura de película nas superfícies axiais e oclusal;

IV. a ocorrência de assentamento oblíquo. 


\section{MATERIAL E MÉTODOS}




\section{MATERIAL E MÉTODOS}

Para a realização deste trabalho trinta troquéis de gesso especial foram obtidos a partir de um troquel-padrão fundido em liga de $\mathrm{Ni}-\mathrm{Cr}$, reproduzido a partir de um dente natural pré-molar superior preparado para coroa total. As i.e.s metálicas e cerâmicas foram confeccionadas e submetidas à análise da espessura de película em diferentes locais, por meio da técnica cimento-análogo, utilizando para isso um material elastomérico fluido. O desajuste vertical, produzido pela simulação da cimentação, foi mensurado em pontos demarcados nas faces externas das i.es. e troquel-padrão. Para possibilitar o desenvolvimento dessa metodologia, utilizaram-se os seguintes materiais:

1) Acrílico autopolimerizante JET (pó e líquido) Clássico, São Paulo - SP.

2) Acrílico autopolimerizante DURALAY (pó e líquido) - Reliance Dental Mfg Co. Worth, IL - USA.

3) Antibolhas PADRON KOTA - Kota Ind. Com. Ltda, São Paulo-SP.

4) Pontas diamantadas esférica $n^{\circ} 1014$ e cilíndrica de extremidade arredondada n 2218 - KG Sorensen, São Paulo-SP.

5) Brocas carbide esféricas $n^{\circ} 2-K G$ Sorensen, São Paulo-SP.

6) Borrachas abrasivas De Deco Dental - São Paulo-SP.

7) Caneta Permanent Marker - Staedtler, Germany. 
8) Carbono líquido spray Arti-Spot Red - BAUSCH Dental Co. of América, San Francisco, CA, USA.

9) Cera para fundição Rainbow opaca - Ceras Rainbow Ltda, Porto Ferreira -SP.

10) Delineador DFL- São Paulo-SP

11) Discos de carborundum Dentorium n. 221, Nova York - USA.

12) Forno elétrico EDG - São Carlos-SP.

13) Gesso tipo IV Durone - Dentsply Ind. e com. Ltda, Petrópolis-RJ.

14) Gotejador de cera - SS White artigos dentários S/A, Rio de Janeiro-RJ.

15) Inclusor a vácuo Whip-Mix, Louisville, C.i. Model B, USA.

16) Jato de óxido de alumínio Trijato - Labor Dental, São Paulo-SP.

17) Lâmina de bisturi no. 15 Feather - Japão.

18) Liga de Ni-Cr - VeraBond II - AlbaDent, Cordelia, CA, USA.

19) Lupa de 4 x Lactona Corporation - USA.

20) Microscópio comparador Mitutoyo Modelo 5050, Código 176-811A Mfg. Co Ltda. - Japan.

21) Pedras de óxido de alumínio SHOFU Dental, Alemanha. 
22) Poliéter - Impregum F Regular- ESPE Dental, Alemanha.

23) Revestimento Micro Fine 1700 - Talladium do Brasil, Curitiba-PR.

24) Silicone de condensação massa densa - Zetaplus, Zhermack SpA- Itália.

25) Silicone de Adição - Elite Mono Viscosidade Média, Zhermack SpA - Itália.

26) Silicone de condensação fluido Xantopren VL Plus, Heraeus Kulzer Co.Alemanha.

27) Sonda exploradora ํㅡ 5 EXD5 Hu-Friedy Chicago USA.

28) Transferidor plástico - Waleu PT, São Paulo-SP.

29) Turbina de alta rotação Kavo Roll Air - Kavo do Brasil, Joinvile-PR.

30) Vaselina sólida - Ind. Farmacêutica Rioquímica Ltda, São José do Rio Preto-SP.

\section{1 - OBTENÇÃO DO TROQUEL-PADRÃO}

Um pré-molar natural superior foi preparado para coroa total pela técnica da silhueta (JANSON et al. $\left.{ }^{41}, 1986\right)$, apresentando as seguintes características:

a) Ângulo de convergência aproximadamente de $10^{\circ}$. 
b) Término cervical nítido em chanfrado, com redução circunferencial de 1,2 mm, localizado próximo à união cemento-esmalte.

c) Redução oclusal de $2,0 \mathrm{~mm}$.

d) Altura face vestibular de 5,0 $\mathrm{mm}$ e face lingual de $4,5 \mathrm{~mm}$.

e) Arredondamento dos ângulos internos.

Para o preparo, foram utilizadas pontas diamantadas esférica e cilíndrica de extremidade arredondada, além de broca multi-laminada cilíndrica de extremidade arredondada.

O dente assim preparado foi duplicado utilizando-se a massa densa do silicone de condensação; o molde foi preenchido com cera liquefeita com o auxílio de um gotejador, obtendo-se uma réplica que foi incluída e fundida em liga de Ni-Cr, pela técnica da cera perdida (figura 4.1). Após o acabamento superficial com pedras de óxido de alumínio e polimento com borrachas abrasivas, este troquel-padrão metálico foi fixado em uma base de resina acrílica. Com o auxílio de um delineador, o troquelpadrão foi posicionado verticalmente no centro de uma moldura retangular de acrílico, com $15 \mathrm{~mm}$ de lado e $20 \mathrm{~mm}$ de altura. Em seguida, a moldura foi preenchida com resina acrílica incolor ativada quimicamente, mantendo o término cervical do preparo cerca de $5 \mathrm{~mm}$ distante da borda superior da base.
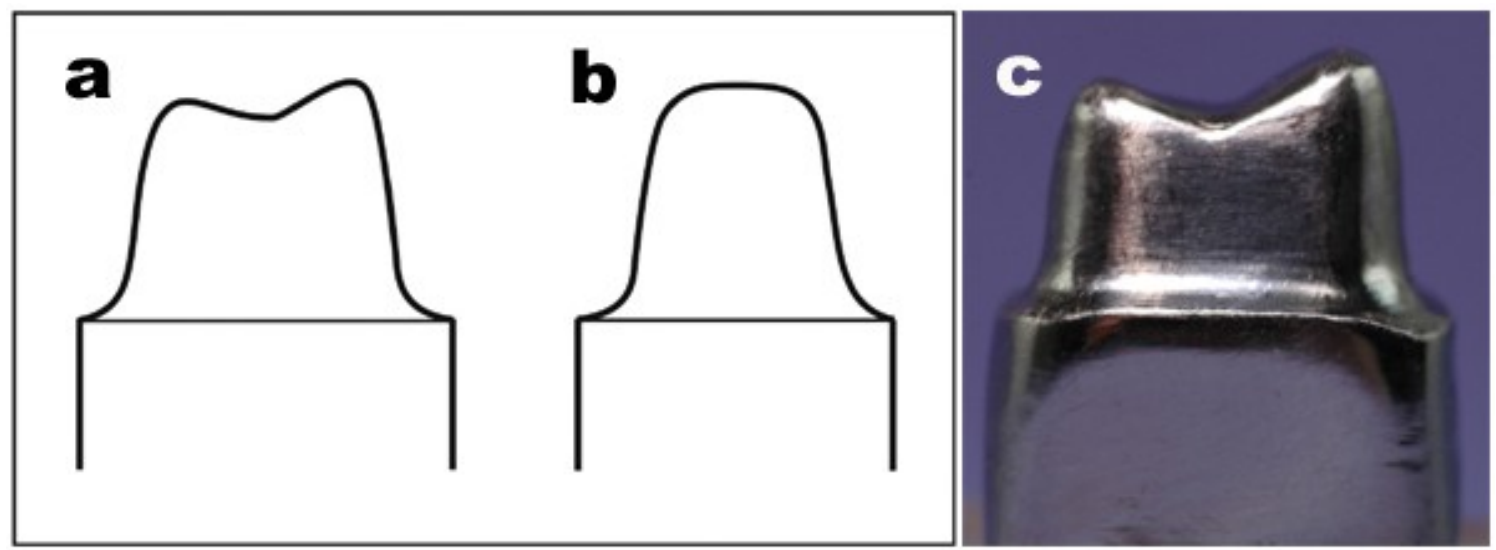
FIGURA 4.1 - ilustração das características do preparo em vista proximal (a) e vestibular (b) e troquel-padrão metálico fundido (c)

A base e o troquel-padrão, por sua vez, foram fixados a uma outra base de resina acrílica Duralay, com o auxílio de um delineador e um transferidor. Na sua porção inferior, essa base de resina Duralay apresentava dois pinos que se encaixavam em dois orifícios preparados na plataforma de um paralelômetro modificado para esse experimento, e que possibilitava o posicionamento do troquel-padrão/base de resina Duralay sempre na mesma posição (figura 4.2).
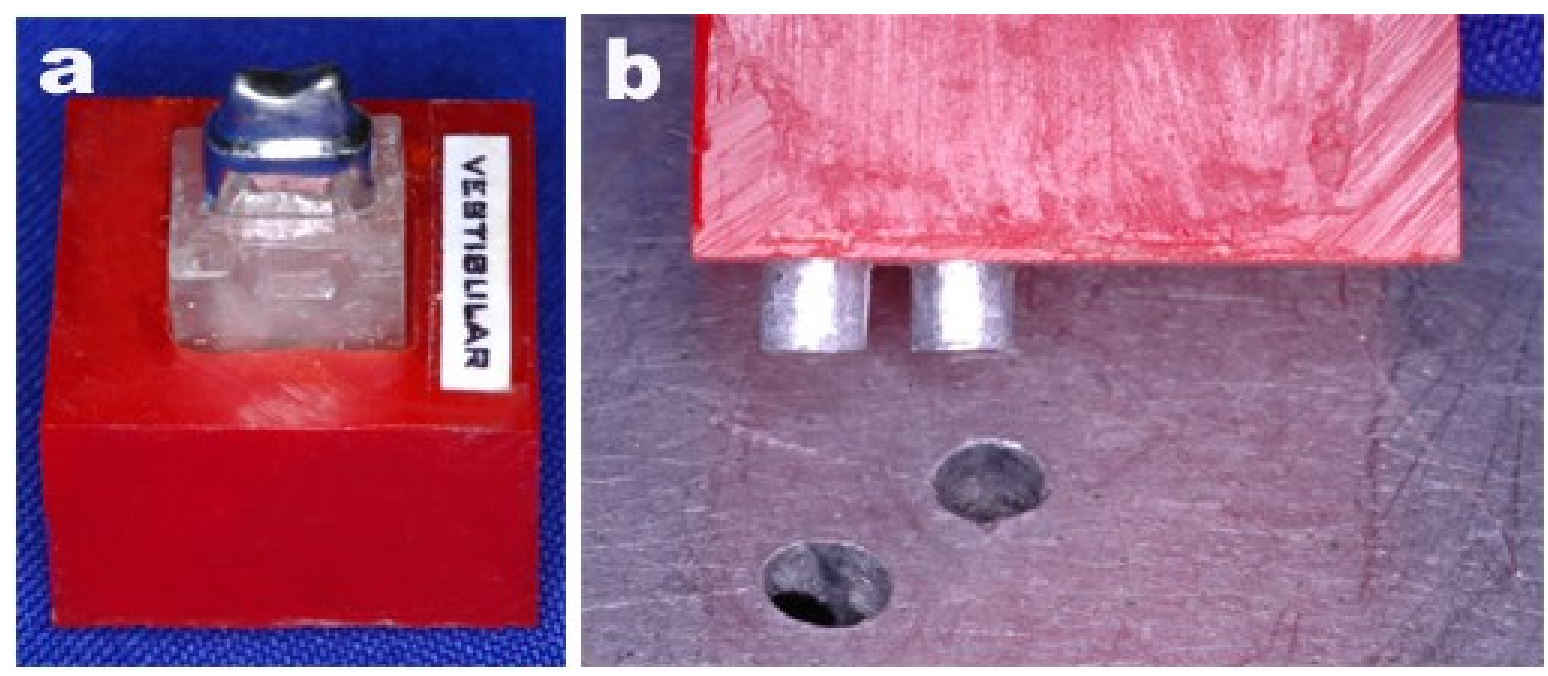

FIGURA 4.2 - a) base e troquel-padrão fixados à base de resina acrílica vermelha; b) pinos na base e orifícios na plataforma do paralelômetro modificado

\section{2 - OBTENÇÃO DOS TROQUÉIS DE GESSO}

A haste vertical do paralelômetro também foi modificada de tal forma que possibilitasse carga estática uniforme durante a tomada da impressão (figura 4.3a).

$\mathrm{Na}$ extremidade inferior da haste vertical posicionou-se um mandril de peça de mão o qual mantinha contato com as moldeiras individuais de resina acrílica, possibilitando uniformidade de espessura do material de moldagem. As moldeiras, que 
se encaixavam à base de resina acrílica incolor, foram confeccionadas com alívio interno de 0,5 mm, em relação à superfície externa do troquel-padrão (figura 4.3b).

$\mathrm{Na}$ extremidade superior da haste vertical confeccionou-se e fixou-se por rosqueamento, um dispositivo para a determinação da carga estática, constituído de aço inoxidável, de tal forma que o conjunto (dispositivo para carga, haste vertical e mandril) perfizesse $2 \mathrm{~kg}$.

O material de moldagem utilizado foi o poliéter Impregum, manipulando em porções iguais de acordo com as instruções do fabricante. A moldeira individual foi antecipadamente pincelada com uma camada de adesivo próprio e seca com jatos de ar. O material espatulado foi levado ao interior da moldeira individual. Realizou-se o assentamento sobre o troquel-padrão por meio de pressão digital e, em seguida, a carga estática foi mantida pelos dispositivos fixados na haste vertical (figura 4.3c).
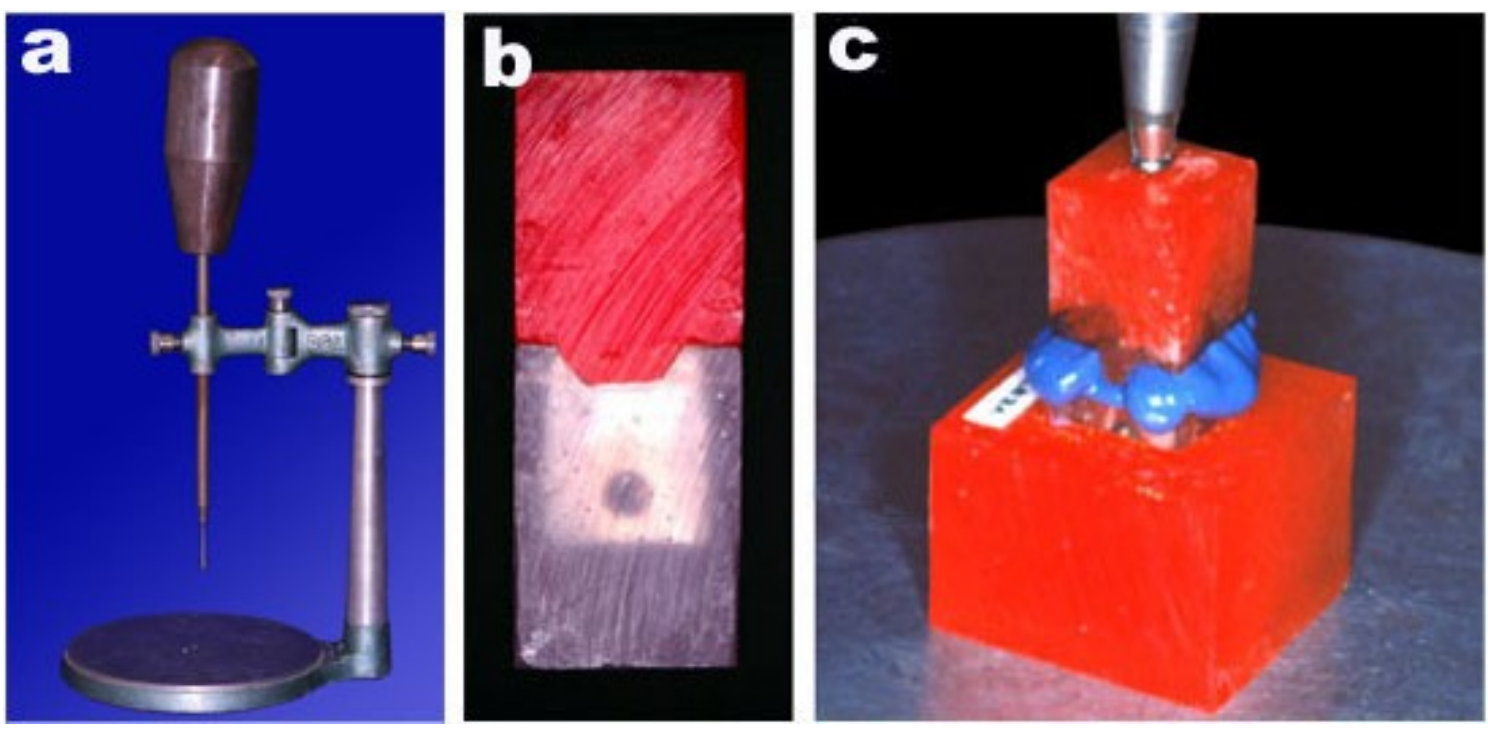

FIGURA 4.3 - a) paralelômetro modificado; b) moldeira encaixada à base de resina acrílica;

c) carga estática sobre a moldeira 
Decorrido o tempo de polimerização do poliéter (8 minutos), a carga estática foi removida e a moldeira individual separada do troquel-metálico. O molde foi vazado com gesso tipo IV, utilizando-se a proporção água/pó recomendada pelo fabricante. Após a cristalização do gesso (aproximadamente 60 minutos), os troquéis foram removidos e avaliados na sua reprodução.

Foram confeccionadas dez moldeiras individuais, sendo que cada uma delas foi utilizada três vezes na mesma seqüência descrita acima. Durante esta etapa, quando alguma área insatisfatória estivesse presente no molde ou troquel de gesso, os procedimentos eram repetidos até que estes fossem julgados satisfatórios. Ao todo, foram obtidos 30 troquéis de gesso.

\section{3 - MARCAÇÕES NO TROQUEL-PADRÃO}

Para avaliar a variação vertical das i.es. após o ajuste interno e o desajuste vertical após a simulação da cimentação, o troquel-padrão recebeu uma marcação a laser no centro de cada uma das faces vestibular, lingual, mesial e distal. Estas marcações tinham a forma circunferencial, com cerca de $200 \mu \mathrm{m}$ de diâmetro, e situavam-se aproximadamente a $2 \mathrm{~mm}$ do término do preparo.

\section{4 - CONFECÇÃO DAS INFRA-ESTRUTURAS}


Os trinta troquéis de gesso foram aleatoriamente divididos em três grupos de dez, numerados de 1 a 30 , e encaminhados a laboratórios comerciais credenciados e familiarizados com a produção de i.es. metálicas e cerâmicas, constituindo:

a) Grupo MC - i.es. metálicas para coroa metalo-cerâmica.

b) Grupo IZ - i.es. cerâmica do sistema In-Ceram Zirconia.

c) Grupo PZ - i.es. cerâmica do sistema Procera AllZircon.

\subsection{1 - INFRA-ESTRUTURAS METÁLICAS PARA COROA METALO-} CERÂMICA

\subsubsection{1 - Obtenção dos padrões de cera}

Os padrões de cera das coroas totais foram obtidos por técnica indireta, utilizando-se cera para fundição e isolamento dos troquéis com duas camadas de isolante próprio.

A cera foi liquefeita sobre a chama de uma lâmpada a álcool e aplicada no troquel por meio de instrumento $\mathrm{PKT} \mathrm{n}^{\circ} 2$, envolvendo toda sua região e formando um fino casquete. Após escultura e acabamento, realizados com o instrumento PKT n 4, o padrão de cera foi removido do troquel e inspecionado, principalmente, para se avaliar a uniformidade da cera nas superfícies internas. A seguir, este foi novamente posicionado sobre o troquel e realizou-se o selamento marginal com o auxílio de uma lupa de $4 \mathrm{x}$.

\subsubsection{2 - Inclusão e fundição}


Fixou-se dois padrões com cera a um pino de cera formador de conduto de alimentação para fundição, em $45^{\circ}$ em relação à face oclusal, na região linguo-oclusal do padrão. Em seguida o padrão foi removido do troquel e fixado com cera liquefeita à base formadora de cadinho. Aplicou-se um agente redutor da tensão superficial em todo o padrão e fixou-se, na base formadora de cadinho, um anel de borracha para inclusão do revestimento.

Para inclusão utilizou-se o revestimento Termocast, na proporção água/pó de 18 $\mathrm{ml}$ para $100 \mathrm{~g}$, com manipulação e inclusão à vácuo em aparelho próprio, usando-se pressão de 15 libras e 60 segundos de tempo de espatulação. Após a inclusão, o conjunto foi levado para uma câmara com pressão constante de 2 Bar. Passados 20 minutos, o anel de borracha e a base foram removidos do revestimento, permitindo sua expansão livre.

Decorridos cerca de 45 minutos da inclusão, o anel de revestimento foi colocado em forno elétrico com a entrada do cadinho voltada para baixo. Procedia-se ao ciclo de aquecimento com elevação lenta da temperatura até $350^{\circ} \mathrm{C}$, mantendo-a por 1 hora. Invertia-se o anel e se elevava a temperatura do forno até $850^{\circ} \mathrm{C}$, mantendo-a por 60 minutos. O cadinho para fundição também recebia o mesmo ciclo de aquecimento do anel e, após armar-se a centrífuga, era posicionado em seu braço. O cadinho recebia a liga Danceramaloy, em quantidade suficiente para se proceder à fundição, realizada com maçarico gás-oxigênio, a 50 psi. Após a fusão da liga, o anel era retirado do forno e adaptado ao braço da centrífuga, que era imediatamente acionada. A seguir o anel era removido do braço da centrífuga e aguardava-se o resfriamento completo para se proceder a desinclusão.

O revestimento foi removido por meio de lavagem com água corrente e escova, após o que se aplicava jato de óxido de alumínio $50 \mu \mathrm{m}$, por cerca de 5 segundos para 
complementar a limpeza do padrão fundido. Os condutos de alimentação foram seccionados com discos de carborundum.

A superfície interna da i.e. foi submetida a um exame minucioso com lupa (de 4x) para possibilitar detecção de irregularidades que, quando presentes, eram removidas com brocas carbide esféricas $\mathrm{n}^{\circ} 2$ em baixa rotação.

A adaptação de cada uma das i.es. metálicas foi avaliada sobre os troquéis que Ihes deram origem. Aquelas que não apresentavam assentamento adequado sobre seu troquel, tinham seu interior ajustado com brocas carbide esféricas $\mathrm{n}^{\circ} 2$ em baixa rotação, nos pontos evidenciados pelo carbono líquido spray Arti-Spot Red. O ajuste prosseguiu até que cada uma das coroas se assentasse, com o menor desajuste possível, sobre seu troquel.

\subsection{2 - INFRA-ESTRUTURAS CERÂMICAS DO SISTEMA IN-CERAM ZIRCONIA}

Após a chegada dos troquéis ao laboratório, prosseguiu-se com a aplicação de uma camada do verniz espaçador do sistema, que ficou $1 \mathrm{~mm}$ aquém da margem do preparo. Os troquéis foram duplicados com silicone de adição e os moldes vazados com o gesso também específico do sistema. De acordo com especificação do fabricante, após duas horas, os troquéis de trabalho foram removidos dos moldes e as bases recortadas a seco, propiciando uma superfície plana. As margens dos preparos foram delimitadas com grafite e os troquéis pincelados com uma fina camada de selador. Nesse instante, o conjunto estava pronto para receber a mistura In-Ceram Zirconia. 


\subsubsection{1 - Preparação da mistura}

Em um frasco de vidro apropriado verteu-se uma ampola de líquido e uma gota de aditivo. O frasco com os dois líquidos foi levado a um aparelho de ultra-som, Vitasonic II, para uma completa homogeneização.

Sobre um vibrador, adicionou-se lentamente $38 \mathrm{~g}$ do pó em pequenas porções, com a ajuda de uma espátula de vidro. Interrompe-se a mistura três vezes para colocar o frasco de vidro por dois minutos no aparelho de ultra-som.

Finalizada a adição do pó, colocou-se o frasco de vidro por sete minutos novamente no aparelho de ultra-som. A suspensão deverá ser agitada até que se obtenha uma consistência regular e homogênea.

Em seguida, submeteu-se a mistura ao vácuo por um minuto. A aplicação da mistura In-Ceram Zirconia sobre os troquéis foi feita com um pincel de pêlo sintético no 4.

Com uma lâmina de bisturi nova, procedeu-se a escultura da restauração. Depois da escultura terminada, foi aplicada uma fina camada de estabilizante e prosseguiu-se com a sinterização.

\subsubsection{2 - Cocção de sinterização no forno Vita Inceramat}

- Aquecimento gradual: 6 horas a $150^{\circ} \mathrm{C}$.

- Aumento gradual de temperatura: 2 horas para atingir $1120^{\circ} \mathrm{C}$.

- Manutenção a $1120^{\circ} \mathrm{C}$ por 2 horas.

- Resfriamento até $400^{\circ} \mathrm{C}$ com o forno fechado.

- Abre-se a porta do forno para resfriar até a temperatura ambiente. 
Após a cocção, a i.e. é facilmente separada do troquel, em função da contração deste, que ocorre durante o processo de sinterização. Pequenas correções da superfície externa deverão ser feitas nesse momento, com pontas diamantadas de granulação fina em baixa rotação. Pequenas trincas poderão ser detectadas com 0 auxílio do líquido (azul) para este fim que acompanha o sistema. Se estas estiverem presentes, faz-se necessária a confecção de nova i.e.

A seguir, a mistura de pó de vidro e água destilada foi aplicada generosamente à superfície externa das i.es. com um pincel. A i.e. foi, então, colocada sobre uma lâmina de platina para a cocção de infiltração.

\subsubsection{3 - Cocção de infiltração no forno Vita Inceramat}

- Aquecimento: 50 minutos para atingir $1140^{\circ} \mathrm{C}$

- Manutenção a $1.140^{\circ} \mathrm{C}$ por 2 horas e trinta minutos.

- Resfriamento até $400^{\circ} \mathrm{C}$ com o forno fechado.

- Abre-se a porta do forno para resfriar até a temperatura ambiente.

Após a infiltração, o vidro excedente deverá ser eliminado com o auxílio de pontas diamantadas de granulação grossa. A seguir, a i.e. foi jateada com óxido de alumínio de $50 \mu \mathrm{m}$ para eliminar os restos de vidro e ser novamente levada ao forno por 10 minutos a $960^{\circ} \mathrm{C}$. Um segundo jateamento com óxido de alumínio de $50 \mathrm{~mm}$ foi efetuado para eliminar o vidro que eventualmente possa ter fluído.

Cada uma das i.es. foi ajustada pelo técnico em prótese dentária sobre os respectivos troquéis originais. Como evidenciador de contatos internos, este utilizou batom para maquiagem, pincelado no interior das peças. Os ajustes foram feitos com pontas diamantadas esféricas em motor elétrico. 


\subsection{3 - INFRA-ESTRUTURAS CERÂMICAS DO SISTEMA PROCERA}

\section{ALLZIRCON}

O Sistema Procera é baseado na tecnologia CAD/CAM - Computer-Aided Design/Computer-Assisted Machining para produção industrial de coroas, facetas, intermediários ou próteses parciais fixas. As i.es. cerâmicas para Procera foram escaneadas em laboratório comercial e fabricada por Procera Sandvik em Estocolmo (Suécia).

O Sistema CAD utiliza um escandidor de troquel e um computador o qual irá converter as informações digitalizadas obtidas pelo escandidor em pontos tridimensionais. Esses pontos reproduzem os contornos do preparo dentário na tela do computador. Após o processamento desses dados é possível por meio de um programa (software) específico, trabalhar sobre este preparo definindo suas margens, estabelecendo uma espessura uniforme da i.e. e tipo de colar cervical. Estas informações são enviadas "via internet" para uma unidade de produção que, sem a presença do modelo, por meio de um programa de computador (CAM) controla a confecção da i.e. desejada, de acordo com as informações recebidas numa composição tridimensional.

\subsubsection{1 - Obtenção da imagem do troquel}

Inicialmente o troquel foi preparado para facilitar a leitura pelo escandidor das dimensões do preparo. O troquel foi verticalmente posicionado no escandidor, 
centralizado em relação ao feixe de laser do equipamento e a ponta de safira posicionada abaixo do término cervical e, enquanto girava lentamente sobre seu próprio eixo, a ponta de safira com uma pressão de $20 \mathrm{~g}$ para manter contato com a superfície do troquel, realizava as leituras ao redor dos $360^{\circ}$ da sua circunferência. A cada $360^{\circ}$ a ponta de safira se desloca superiormente $200 \mu \mathrm{m}$, até o completo mapeamento do preparo onde em média obtem-se 50.000 pontos digitalizados. A imagem obtida é visualizada na tela do computador e verificada na sua precisão e continuidade.

\subsubsection{2 - Envio dos dados}

Os dados do preparo e o desenho e espessura desejados da i.e. foram transferidos para a unidade de produção na Suécia.. Estabeleceu-se em 0,6 mm a espessura da i.e. a ser fabricada e selecionou-se o ângulo do perfil de emergência desejado em $20^{\circ}$. O espaço para o agente cimentante foi automaticamente estabelecido por meio do programa do computador, esperando-se espessura uniforme de aproximadamente $50 \mu \mathrm{m}$, de acordo com o próprio fabricante.

\subsubsection{3 - Confecção das infra-estruturas}

Na unidade de produção, são confeccionado dois troquéis, um em resina e outro fresado a partir de um bloco de refratário. Este último tem suas dimensões acrescidas de aproximadamente $20 \%$, em relação às características encaminhadas, para compensar a contração da estrutura cerâmica. Óxidos de zircônio e alumina altamente puros $(99,9 \%)$ são compactados e secos contra esse troquel a uma pressão de 2 toneladas. A forma externa da i.e. é obtida por usinagem por meio de outro computador que comanda o contorno externo e a espessura determinada para a futura i.e. 
Finalmente, esta é sinterizada à temperatura de $1550^{\circ} \mathrm{C}$, durante uma hora. As i.es. passaram por um controle de qualidade e sua adaptação foi avaliada por meio do troquel de resina.

Em seguida, as i.es. foram encaminhadas por correio para o laboratório que gerou as informações digitais.

\section{5 - ADAPTAÇÃO DAS INFRA-ESTRUTURAS}

Após a obtenção das 30 i.es., estas receberam uma marcação com caneta permanente no centro de cada uma das faces em alinhamento com as marcações a laser do troquel-padrão. Estas marcações tinham a forma circunferencial e situavam-se aproximadamente a $1 \mathrm{~mm}$ das margens cervicais das i.es. Em seguida, elas foram avaliadas quanto ao seu assentamento sobre o troquel-padrão metálico por meio de sonda exploradora ํo 5 e lupa (figura 4.4). Nenhuma das i.es. teve suas margens ajustadas durante a avaliação. As i.es. dos grupos MC e IZ necessitaram de ajuste de sua superfície interna, pois existia íntimo contato entre as paredes das i.es. e do

preparo dental, impedindo seu completo assentamento. Seguindo a metodologia descrita por DAVIS; KELLY; CAMPBELL ${ }^{18}$ (1989), WHITE; SORENSEN; KANG ${ }^{90}$ (1991) e WHITE; KIPNIS ${ }^{89}$ (1993), isto pôde ser detectado utilizando-se um elastômero de consistência fluida como evidenciador de contatos internos. O material era espatulado de acordo com as instruções do fabricante, levado ao interior das i.es. com um pincel e, em seguida, assentadas sob pressão digital sobre o troquel-padrão. Após a presa do material (10 minutos), o interior das i.es. era avaliado e as áreas que mostrassem contato com o troquel metálico, por transparência do elastômero, foram ajustadas com 
pontas esféricas diamantadas em alta rotação, sob refrigeração. Este procedimento repetiu-se até que fosse conseguida uma adaptação clinicamente aceitável das i.es. do grupo MC e IZ. A avaliação da película do elastômero revelou que nenhuma das i.es. do grupo PZ necessitaria de ajuste de sua superfície interna.

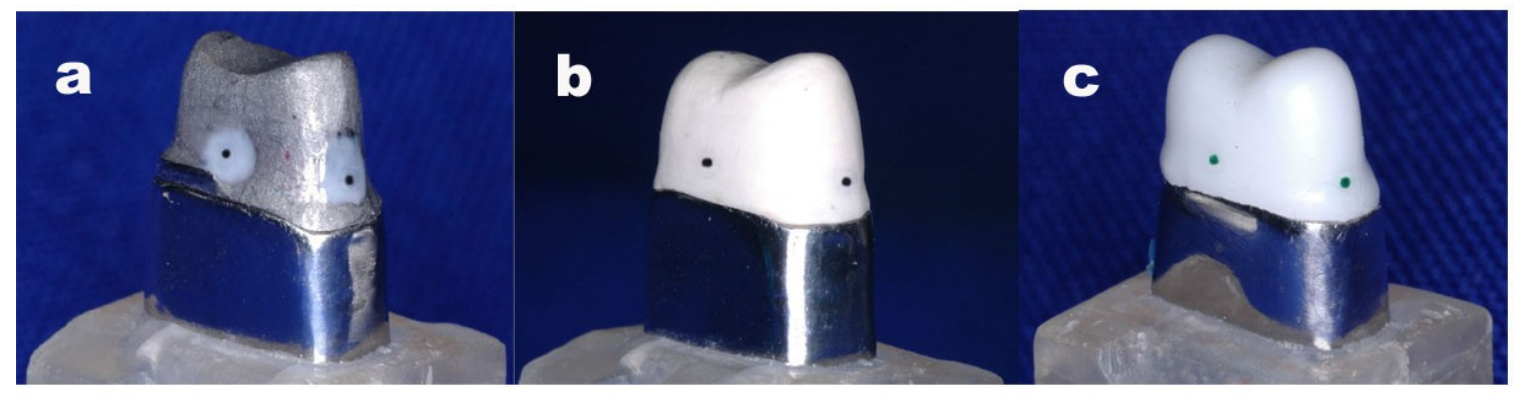

FIGURA 4.4 - i.e.s. assentadas sobre o troquel-padrão metálico: a) i.e. do grupo MC;

b) i.e. do grupo IZ; c) i.e. do grupo PZ

Previamente ao ajuste interno, as i.es. foram posicionadas sobre o troquelpadrão e mantidas em posição por um grampo confeccionado em fio ortodôntico 1,2 $\mathrm{mm}$. Desta maneira, o conjunto era levado para um microscópio Mitutoyo TM - modelo 5050, código 176-811A, com aumento de 150 vezes (ocular de 15x e objetiva de 10x) cabeçotes micrométricos (código 164-162), mostrador digital embutido e precisão de $1 \mu \mathrm{m}$. Ali, a distância vertical entre o limite cervical do ponto circunferencial presente nas i.es. e o limite coronal do ponto presente no troquel-padrão foi mensurada três vezes por face.

Depois que as i.es. foram ajustadas, estas foram posicionadas da mesma forma sobre o troquel-padrão e o conjunto levado novamente ao microscópio para a mensuração da variação vertical decorrente do ajuste interno. Esta distância foi aferida 
da mesma forma descrita anteriormente. A diferença entre a medida inicial e a medida final representou a variação vertical decorrente da adaptação das i.es.

\section{6 - AVALIAÇÃO DO DESAJUSTE VERTICAL E DA ESPESSURA DE}

\section{PELÍCULA}

\subsection{1 - AVALIAÇÃO DO DESAJUSTE VERTICAL}

Novamente, as i.es. foram posicionadas sobre o troquel-padrão e mantidas em posição pelo grampo confeccionado em fio ortodôntico. Em seguida, foram levadas ao microscópio e a distância vertical entre os pontos foi mais uma vez mensurada da mesma forma. Estes valores foram adotados como os valores iniciais para a avaliação do desajuste vertical decorrente da simulação da cimentação das i.es.

A simulação da cimentação foi realizada por meio da técnica denominada cimento-análogo, originalmente descrita por McLEAN; von FRAUNHOFER ${ }^{57}$, em 1971. Selecionou-se, como material para a simulação da cimentação, um silicone de condensação com consistência fluida. Este foi escolhido por permitir melhor contraste com o silicone de adição com consistência média, utilizado para a inclusão da película de cimento-análogo.

A escolha de um silicone de consistência fluida também se deu por conta de alguns fatores de similaridade com os cimentos de fosfato de zinco e de ionômero de vidro, como tempo de trabalho e tempo de presa, manipulação e escoamento, conforme recomendado por McLEAN; von FRAUNHOFER ${ }^{57}$ (1971), DAVIS; KELLY; CAMPBELL ${ }^{18}$ (1989) e MAY et al. ${ }^{55}$ (1998). 
Comprimentos iguais de silicone fluido e pasta catalisadora foram dosados e manipulados em um bloco de papel. A mistura obtida foi pincelada em uma fina camada na superfície interna das i.es., que foram levadas ao troquel-padrão e assentadas sob pressão digital. Em seguida, o conjunto foi levado ao paralelômetro modificado e recebeu carga estática de $2 \mathrm{~kg}$, mantida por 10 minutos (figura 4.5).

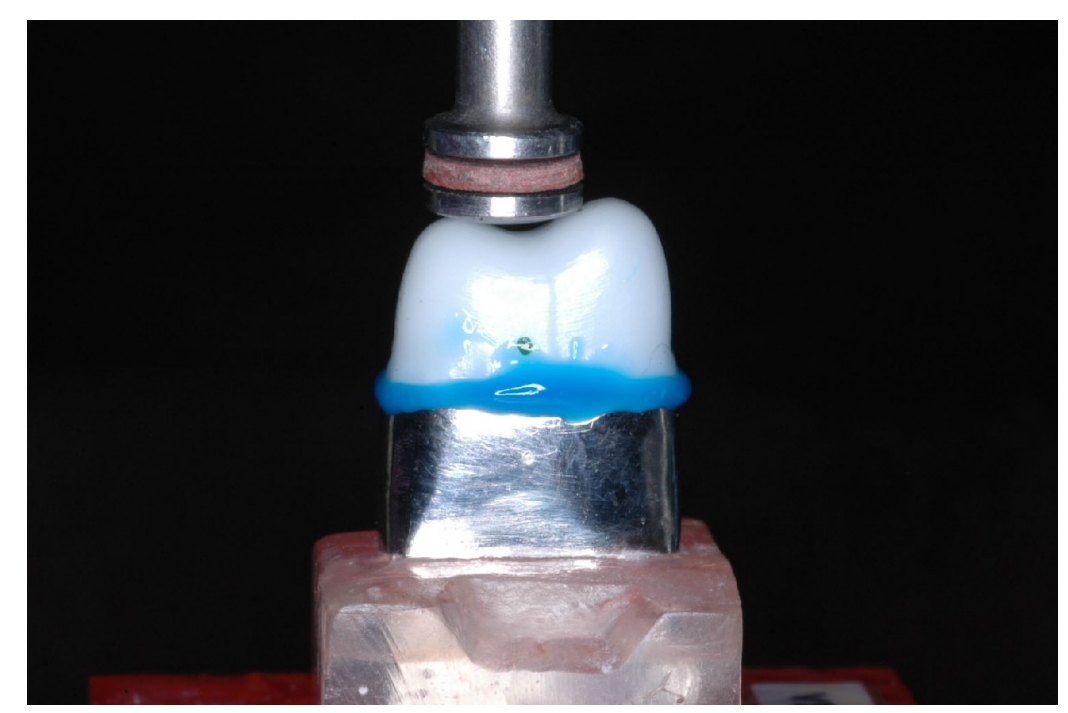

FIGURA 4.5 - i.e. do grupo PZ assentada sobre o troquel-padrão metálico sob carga estática

Após a completa polimerização do elastômero (10 minutos), os excessos foram removidos com auxílio de uma lâmina de bisturi no 15, e o conjunto foi levado mais uma vez ao microscópio e foram obtidos os valores finais do desajuste vertical. A diferença entre a medida inicial e a medida final representou a variação de desajuste vertical decorrente da cimentação das i.es.

\subsection{2 - CAPTURA DA PELÍCULA DE CIMENTO-ANÁLOGO}


As i.es. foram removidas do troquel-padrão e, geralmente, a película de elastômero permanecia em seu interior (figura 4.6a). Para conseguir sua remoção sem danos, injetou-se silicone de adição com consistência média com pontas de automistura e dispositivo próprio (figura 4.6b), até que este preenchesse totalmente a porção interna da i.e. Demarcou-se a face vestibular do conjunto, bem como o posicionamento espacial da película identificando o centro da mesma, no sentido vestíbulo-lingual.
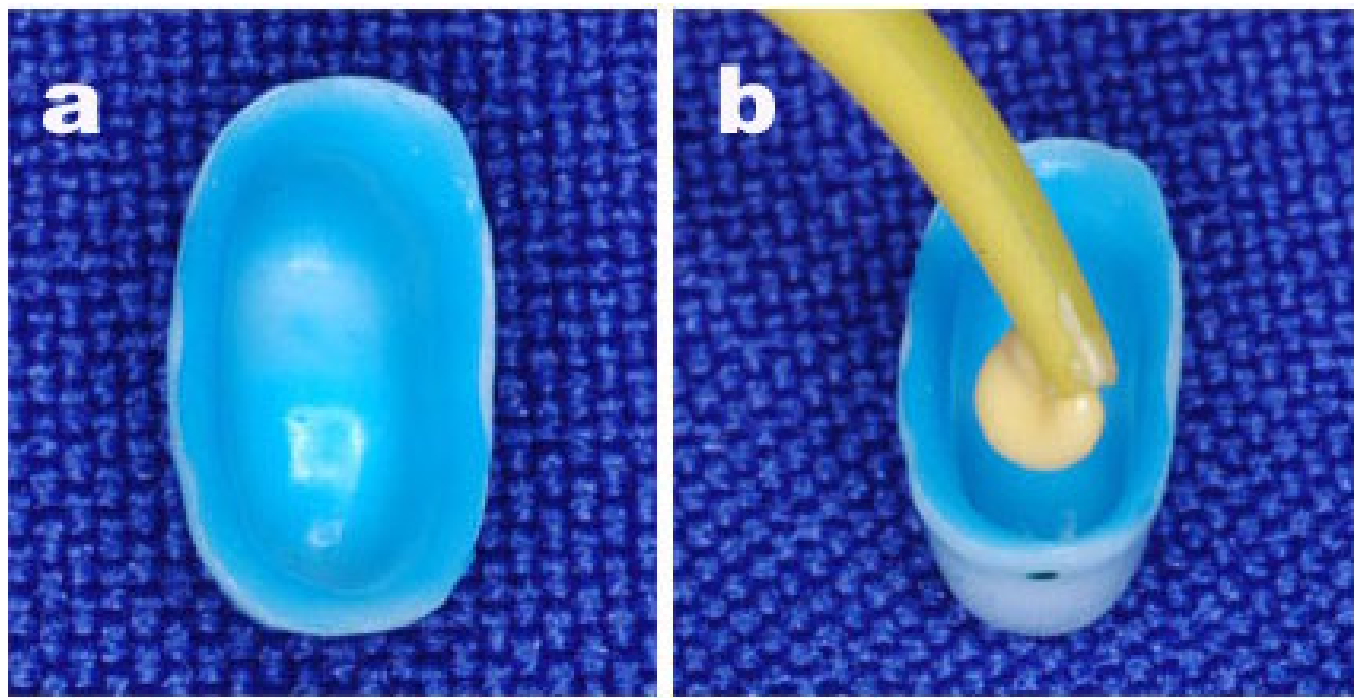

FIGURA 4.6 - a) película de elastômero no interior da i.e.; b) silicone de consistência média sendo injetado no interior da i.e. para captura da película

Decorrido o tempo de polimerização do material, retirou-se o conjunto do interior da i.e., observando-se a película de silicone fluido (azul) aderida ao silicone de consistência média (amarela). Posicionou-se, em uma segunda fase, este conjunto no centro de um caixa acrílica transparente com $2 \mathrm{~cm}$ de altura x 1,5 mm de largura $\times 1,5 \mathrm{~mm}$ de profundidade, contendo uma ranhura que permitia identificação do centro do dente, no sentido vestíbulolingual. A caixa acrílica, depois de posicionado o conjunto, foi preenchida com o mesmo silicone de consistência média, obtendo-se uma peça única após sua polimerização, 
contendo, no seu interior, a película de elastômero fluido. Tendo como orientação a face vestibular e o centro do dente, realizou-se um corte único com uma lâmina de barbear no sentido vestíbulo-lingual, dividindo o bloco em dois lados: hemiface A e hemiface B (figura 4.7).

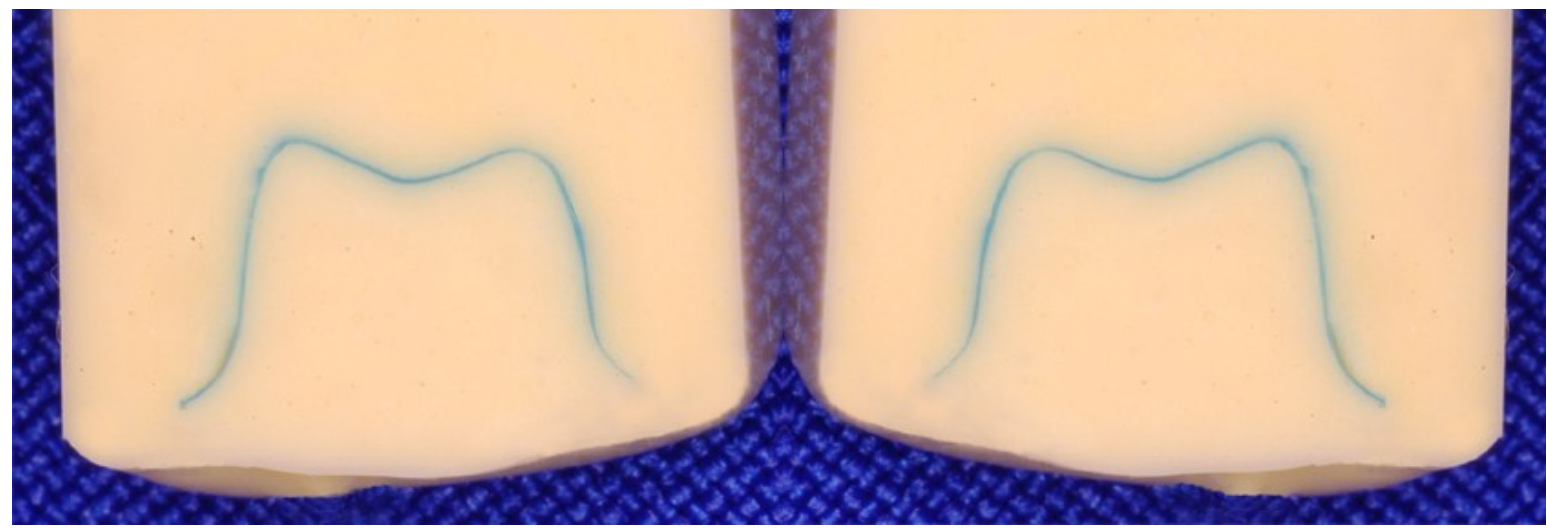

FIGURA 4.7 - bloco de silicona seccionado ao meio no sentido vestíbulo-lingual contendo a película de elastômero em seu interior

Quando a película permaneceu no troquel padrão, procedeu-se de forma semelhante, exceto que a incorporação deu-se pela superfície externa.

\subsection{3 - DEMARCAÇÃO DOS PONTOS DE LEITURA}

Para cada hemiface foram selecionados sete pontos a serem analisados no microscópio comparador, correspondentes as seguintes regiões (figura 4.8):
a) Porção cervical da parede vestíbulo-axial.
b) Porção intermediária da parede vestíbulo-axial.
c) Porção superior da cúspide vestibular. 
d) Porção inferior do sulco mesio-distal.

e) Porção superior da cúspide lingual.

f) Porção intermediária da parede línguo-axial.

g) Porção cervical da parede línguo-axial.

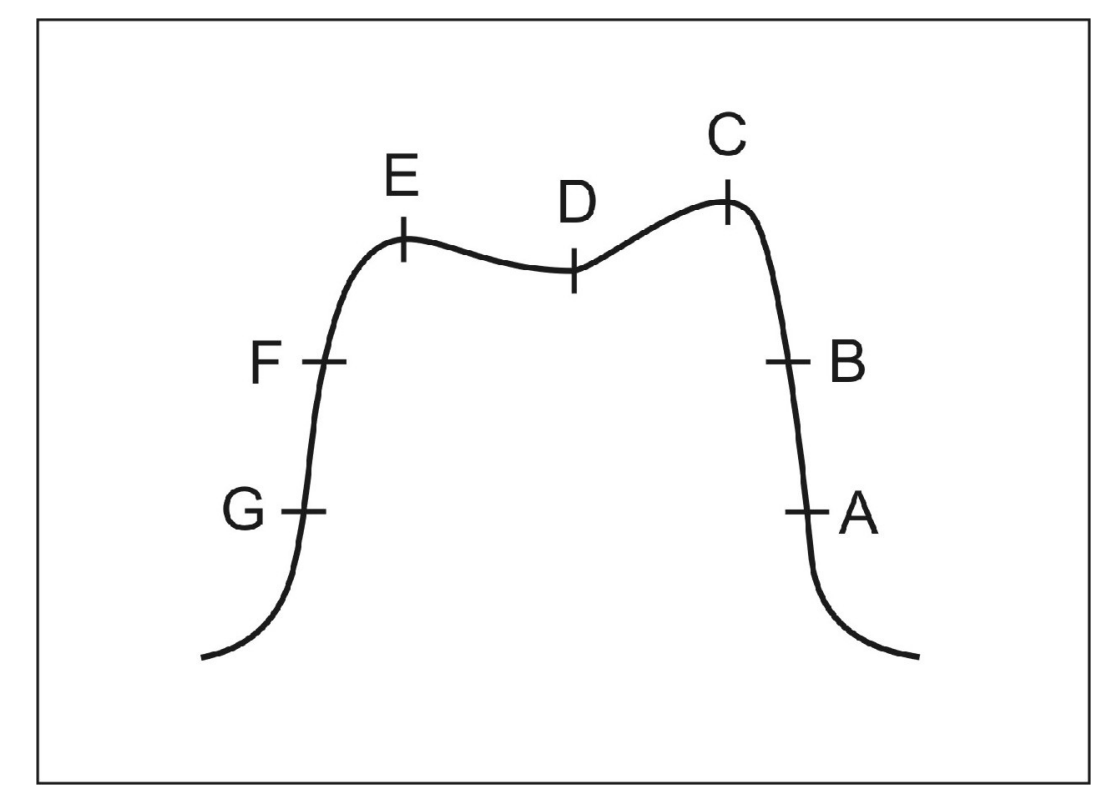

FIGURA 4.8 - ilustração dos pontos de leitura da espessura de película

\subsection{4 - MENSURAÇÃO DA ESPESSURA DE PELÍCULA DE CIMENTO- ANÁLOGO EM MICROSCÓPIO COMPARADOR}

Para a análise da espessura de película, utilizou-se o mesmo microscópio comparador. Ambas as hemiface do espécime de silicone, de cada corpo de prova, foram levadas ao microscópio, ajustando-se a leitura sempre na linha vertical do retículo. Cada leitura foi realizada três vezes, obtendo-se a média para cada ponto correspondente às sete regiões pré-determinadas. Foram realizadas 21 leituras para cada hemiface e um total de 1.260 para todos os grupos no experimento. 
Os dados da análise do desajuste vertical e da espessura de película foram anotados para formação de tabelas e posterior análise estatística.

\section{7 - ANÁLISE ESTATÍSTICA}

Os resultados obtidos foram submetidos a testes estatísticos de Análise de Variância, teste de Tukey e coeficiente de correlação de Pearson. Em todos os testes foi adotado nível de significância de $5 \%(p<0,05)$. 


\section{RESULTADOS}




\section{RESULTADOS}

\section{1 - ADAPTAÇÃO DAS INFRA-ESTRUTURAS}

As i.es. dos grupos $M C$ e $I Z$ sofreram ajuste de sua superfície interna para otimizar seu assentamento. Nenhuma das i.es. do grupo PZ necessitou de ajuste interno.

Os valores médios das variações verticais, obtidas após o ajuste interno das i.es. metálicas para metalo-cerâmica (grupo $\mathrm{MC}$ ) e i.es. cerâmicas do sistema In-Ceram Zirconia (grupo IZ), foram agrupados na tabela 5.1 e 5.2, respectivamente.

Os valores expressos com sinal negativo demonstram o desajuste negativo da i.e. (aproximação entre margem da i.e. e término cervical do preparo) e os valores positivos demonstram o desajuste positivo (distanciamento entre margem da i.e. e término cervical do preparo).

TABELA 5.1 - Média das variações verticais $(\mu \mathrm{m})$ para as faces vestibular $(V)$, lingual (L), mesial (M) e distal (D) das i.es. metálicas para metalo-cerâmica.

\begin{tabular}{|c|c|c|c|c|c|}
\hline $\begin{array}{c}\text { corpo de } \\
\text { prova }\end{array}$ & $\mathbf{V}$ & $\mathbf{L}$ & $\mathbf{M}$ & $\mathbf{D}$ & MÉDIA \\
\hline $\mathbf{0 1}$ & -63 & -26 & -37 & -33 & $\mathbf{- 3 9 , 7}$ \\
\hline $\mathbf{0 2}$ & -48 & -32 & -58 & -50 & $\mathbf{- 4 7 , 0}$ \\
\hline $\mathbf{0 3}$ & -45 & -13 & -17 & -18 & $\mathbf{- 2 3 , 2}$ \\
\hline $\mathbf{0 4}$ & -17 & -58 & -23 & -9 & $\mathbf{- 2 6 , 7}$ \\
\hline $\mathbf{0 5}$ & -115 & -363 & -209 & -205 & $\mathbf{- 2 2 3 , 0}$ \\
\hline $\mathbf{0 6}$ & -89 & -21 & -24 & -60 & $\mathbf{- 4 8 , 5}$ \\
\hline $\mathbf{0 7}$ & -117 & -4 & -11 & -49 & $\mathbf{- 4 5 , 2}$ \\
\hline $\mathbf{0 8}$ & -9 & -6 & -4 & -13 & $\mathbf{- 8 , 0}$ \\
\hline $\mathbf{0 9}$ & -84 & -12 & -99 & -53 & $\mathbf{- 6 2 , 0}$ \\
\hline $\mathbf{1 0}$ & -35 & -34 & -38 & -17 & $\mathbf{- 3 1 , 0}$ \\
\hline $\mathbf{M E ́} \mathbf{D I A}$ & $-\mathbf{- 6 2 , 2}$ & $\mathbf{- 5 6 , 9}$ & $\mathbf{- 5 2 , 0}$ & $-\mathbf{5 0 , 7}$ & $\mathbf{- 5 5 , 4}$ \\
\hline
\end{tabular}


TABELA 5.2 - Média das variações verticais $(\mu \mathrm{m})$ para as faces vestibular $(\mathrm{V})$, lingual (L), mesial (M) e distal (D) das i.es. cerâmicas do sistema In-Ceram Zirconia.

\begin{tabular}{|c|c|c|c|c|c|}
\hline $\begin{array}{c}\text { corpo de } \\
\text { prova }\end{array}$ & $\mathbf{V}$ & $\mathbf{L}$ & $\mathbf{M}$ & $\mathbf{D}$ & MÉDIA \\
\hline $\mathbf{1 1}$ & -6 & -22 & -16 & -5 & $\mathbf{- 1 2}$ \\
\hline $\mathbf{1 2}$ & -6 & -28 & -10 & -1 & $\mathbf{- 1 1}$ \\
\hline $\mathbf{1 3}$ & -23 & -14 & -10 & 2 & $\mathbf{- 1 1}$ \\
\hline $\mathbf{1 4}$ & -1 & -2 & 1 & 0 & $-\mathbf{- 1}$ \\
\hline $\mathbf{1 5}$ & -9 & -4 & -5 & -9 & $-\mathbf{7}$ \\
\hline $\mathbf{1 6}$ & -14 & -29 & -41 & -9 & $\mathbf{- 2 3}$ \\
\hline $\mathbf{1 7}$ & -61 & -7 & -41 & -19 & $\mathbf{- 3 2}$ \\
\hline $\mathbf{1 8}$ & -24 & -11 & -8 & -6 & $-\mathbf{- 1 2}$ \\
\hline $\mathbf{1 9}$ & -37 & -12 & -23 & -18 & $\mathbf{- 2 3}$ \\
\hline $\mathbf{2 0}$ & -44 & -12 & -75 & -13 & $\mathbf{- 3 6}$ \\
\hline $\mathbf{M E ́} D I A$ & $-\mathbf{- 2 3}$ & $-\mathbf{- 1 4}$ & -23 & $-\mathbf{8}$ & $\mathbf{- 1 7}$ \\
\hline
\end{tabular}

\section{2 - DESAJUSTE VERTICAL}

Os valores médios dos desajustes verticais, obtidos após a simulação da cimentação das i.es. metálicas para metalo-cerâmica (grupo $M C$ ) foram agrupados na tabela 5.3. Da mesma forma, os valores médios dos desajustes verticais das i.es. cerâmicas dos sistemas In-Ceram Zirconia (grupo IZ) e Procera AllZircon (grupo PZ) estão representadas nas tabelas 5.4 e 5.5, respectivamente. 
TABELA 5.3 - Média dos desajustes verticais $(\mu \mathrm{m})$ para as faces vestibular $(\mathrm{V})$, lingual (L), mesial (M) e distal (D), após a simulação da cimentação das i.es. metálicas para metalo-cerâmica.

\begin{tabular}{|c|c|c|c|c|c|}
\hline $\begin{array}{c}\text { corpo de } \\
\text { prova }\end{array}$ & $\mathbf{V}$ & $\mathbf{L}$ & $\mathbf{M}$ & $\mathbf{D}$ & MÉDIA \\
\hline $\mathbf{0 1}$ & -34 & -19 & 24 & -29 & $\mathbf{- 1 5}$ \\
\hline $\mathbf{0 2}$ & 18 & 59 & 3 & -22 & $\mathbf{1 5}$ \\
\hline $\mathbf{0 3}$ & 23 & -14 & -13 & 16 & $\mathbf{3}$ \\
\hline $\mathbf{0 4}$ & -14 & 32 & -18 & -18 & $-\mathbf{5}$ \\
\hline $\mathbf{0 5}$ & -30 & -17 & -47 & -11 & $\mathbf{- 2 6}$ \\
\hline $\mathbf{0 6}$ & -14 & -6 & -16 & -13 & $\mathbf{- 1 2}$ \\
\hline $\mathbf{0 7}$ & -3 & -21 & -20 & -21 & $-\mathbf{- 1 6}$ \\
\hline $\mathbf{0 8}$ & -14 & 75 & 13 & 47 & $\mathbf{3 0}$ \\
\hline $\mathbf{0 9}$ & -16 & 6 & 16 & -8 & $\mathbf{- 1}$ \\
\hline $\mathbf{1 0}$ & -54 & 18 & -31 & 4 & $\mathbf{- 1 6}$ \\
\hline MÉDIA & $-\mathbf{- 1 4}$ & $\mathbf{1 1}$ & $\mathbf{- 9}$ & $-\mathbf{6}$ & $\mathbf{- 4}$ \\
\hline
\end{tabular}

TABELA 5.4 - Média dos desajustes verticais $(\mu \mathrm{m})$ para as faces vestibular $(\mathrm{V})$, lingual (L), mesial (M) e distal (D), após a simulação da cimentação das i.es. cerâmicas do sistema In-Ceram Zirconia.

\begin{tabular}{|c|c|c|c|c|c|}
\hline $\begin{array}{c}\text { corpo de } \\
\text { prova }\end{array}$ & $\mathbf{V}$ & $\mathbf{L}$ & $\mathbf{M}$ & $\mathbf{D}$ & MÉDIA \\
\hline $\mathbf{1 1}$ & 17 & 16 & -5 & -12 & $\mathbf{4}$ \\
\hline $\mathbf{1 2}$ & -41 & 36 & 9 & -8 & $\mathbf{- 1}$ \\
\hline $\mathbf{1 3}$ & 30 & 14 & -7 & -15 & $\mathbf{6}$ \\
\hline $\mathbf{1 4}$ & -18 & 21 & 4 & 1 & $\mathbf{2}$ \\
\hline $\mathbf{1 5}$ & -7 & 21 & 20 & 15 & $\mathbf{1 2}$ \\
\hline $\mathbf{1 6}$ & -6 & 13 & 44 & 16 & $\mathbf{1 7}$ \\
\hline $\mathbf{1 7}$ & -17 & 10 & 31 & 12 & $\mathbf{9}$ \\
\hline $\mathbf{1 8}$ & -7 & 3 & 19 & 10 & $\mathbf{6}$ \\
\hline $\mathbf{1 9}$ & -21 & 3 & -2 & -7 & $-\mathbf{7}$ \\
\hline $\mathbf{2 0}$ & -7 & -6 & 34 & 8 & $\mathbf{7}$ \\
\hline MÉDIA & $-\mathbf{- 8}$ & $\mathbf{1 3}$ & $\mathbf{1 5}$ & $\mathbf{2}$ & $\mathbf{6}$ \\
\hline
\end{tabular}


TABELA 5.5 - Média dos desajustes verticais $(\mu \mathrm{m})$ para as faces vestibular $(\mathrm{V})$, lingual (L), mesial (M) e distal (D), após a simulação da cimentação das i.es. cerâmicas do sistema Procera AllZircon.

\begin{tabular}{|c|c|c|c|c|c|}
\hline $\begin{array}{c}\text { corpo de } \\
\text { prova }\end{array}$ & $\mathbf{V}$ & $\mathbf{L}$ & $\mathbf{M}$ & $\mathbf{D}$ & MÉDIA \\
\hline $\mathbf{2 1}$ & -58 & 62 & 2 & -3 & $\mathbf{1}$ \\
\hline $\mathbf{2 2}$ & -92 & 41 & 68 & -61 & $\mathbf{- 1 1}$ \\
\hline $\mathbf{2 3}$ & -39 & -46 & -55 & -14 & $\mathbf{- 3 9}$ \\
\hline $\mathbf{2 4}$ & -64 & 58 & -7 & 10 & $\mathbf{- 1}$ \\
\hline $\mathbf{2 5}$ & -40 & 14 & -20 & 0 & $\mathbf{- 1 2}$ \\
\hline $\mathbf{2 6}$ & -94 & 27 & -29 & -10 & $\mathbf{- 2 7}$ \\
\hline $\mathbf{2 7}$ & -34 & 21 & -31 & 3 & $\mathbf{- 1 0}$ \\
\hline $\mathbf{2 8}$ & -8 & 7 & -58 & -4 & $\mathbf{- 1 6}$ \\
\hline $\mathbf{2 9}$ & -45 & -53 & -26 & -29 & $\mathbf{- 3 8}$ \\
\hline $\mathbf{3 0}$ & -38 & 3 & -79 & 90 & $-\mathbf{6}$ \\
\hline MÉDIA & $-\mathbf{- 5 1}$ & $\mathbf{1 3}$ & $\mathbf{- 2 4}$ & $\mathbf{- 2}$ & $\mathbf{- 1 6}$ \\
\hline
\end{tabular}

\section{3 - ESPESSURA DE PELÍCULA}

As médias da espessura de película de elastômero, nos diferentes pontos das i.es. metálicas para metalo-cerâmica (grupo MC) foram agrupadas na tabela 5.6. Da mesma forma, as médias da espessura de película para as i.es. cerâmicas dos sistemas In-Ceram Zirconia (grupo IZ) e Procera AllZircon (grupo PZ) estão representadas nas tabelas 5.7 e 5.8 , respectivamente. 
TABELA 5.6 - Médias de espessura de película $(\mu \mathrm{m})$ nos diferentes pontos das i.es. metálicas para metalo-cerâmica.

\begin{tabular}{|c|c|c|c|c|c|c|c|}
\hline $\begin{array}{c}\text { corpo de } \\
\text { prova }\end{array}$ & A & B & C & D & E & F & G \\
\hline $\mathbf{0 1}$ & 60 & 17 & 80 & 117 & 45 & 20 & 132 \\
\hline $\mathbf{0 2}$ & 68 & 12 & 44 & 53 & 41 & 11 & 87 \\
\hline $\mathbf{0 3}$ & 61 & 14 & 37 & 68 & 42 & 10 & 73 \\
\hline $\mathbf{0 4}$ & 122 & 26 & 83 & 78 & 37 & 11 & 118 \\
\hline $\mathbf{0 5}$ & 100 & 43 & 48 & 87 & 60 & 34 & 99 \\
\hline $\mathbf{0 6}$ & 20 & 17 & 31 & 89 & 98 & 13 & 37 \\
\hline $\mathbf{0 7}$ & 74 & 9 & 46 & 59 & 66 & 12 & 73 \\
\hline $\mathbf{0 8}$ & 25 & 18 & 77 & 131 & 100 & 16 & 77 \\
\hline $\mathbf{0 9}$ & 50 & 14 & 35 & 23 & 16 & 13 & 108 \\
\hline $\mathbf{1 0}$ & 62 & 7 & 63 & 88 & 84 & 13 & 97 \\
\hline MÉDIA & $\mathbf{6 4}$ & $\mathbf{1 8}$ & $\mathbf{5 4}$ & $\mathbf{7 9}$ & $\mathbf{5 9}$ & $\mathbf{1 5}$ & $\mathbf{9 0}$ \\
\hline
\end{tabular}

TABELA 5.7 - Médias de espessura de película $(\mu \mathrm{m})$ nos diferentes pontos das i.es. cerâmicas do sistema In-Ceram Zirconia.

\begin{tabular}{|c|c|c|c|c|c|c|c|}
\hline $\begin{array}{c}\text { corpo de } \\
\text { prova }\end{array}$ & A & B & C & D & E & F & G \\
\hline $\mathbf{1 1}$ & 59 & 56 & 81 & 79 & 40 & 96 & 63 \\
\hline $\mathbf{1 2}$ & 61 & 139 & 92 & 58 & 58 & 25 & 48 \\
\hline $\mathbf{1 3}$ & 84 & 45 & 35 & 61 & 45 & 55 & 44 \\
\hline $\mathbf{1 4}$ & 69 & 56 & 28 & 80 & 60 & 69 & 70 \\
\hline $\mathbf{1 5}$ & 106 & 61 & 64 & 86 & 68 & 54 & 38 \\
\hline $\mathbf{1 6}$ & 161 & 46 & 105 & 49 & 22 & 63 & 109 \\
\hline $\mathbf{1 7}$ & 120 & 54 & 53 & 61 & 57 & 82 & 96 \\
\hline $\mathbf{1 8}$ & 152 & 65 & 29 & 37 & 20 & 124 & 141 \\
\hline $\mathbf{1 9}$ & 123 & 67 & 67 & 116 & 60 & 113 & 80 \\
\hline $\mathbf{2 0}$ & 60 & 43 & 43 & 107 & 63 & 33 & 74 \\
\hline MÉDIA & $\mathbf{1 0 0}$ & $\mathbf{6 3}$ & $\mathbf{6 0}$ & $\mathbf{7 3}$ & $\mathbf{4 9}$ & $\mathbf{7 1}$ & $\mathbf{7 6}$ \\
\hline
\end{tabular}


TABELA 5.8 - Médias de espessura de película $(\mu \mathrm{m})$ nos diferentes pontos das i.es. cerâmicas do sistema Procera AllZircon.

\begin{tabular}{|c|c|c|c|c|c|c|c|}
\hline & \multicolumn{7}{|c}{ GRUPO PZ } \\
\hline $\begin{array}{c}\text { corpo de } \\
\text { prova }\end{array}$ & A & B & C & D & E & F & G \\
\hline $\mathbf{2 1}$ & 96 & 103 & 23 & 117 & 59 & 43 & 57 \\
\hline $\mathbf{2 2}$ & 128 & 143 & 30 & 118 & 93 & 18 & 35 \\
\hline $\mathbf{2 3}$ & 29 & 38 & 189 & 99 & 49 & 122 & 119 \\
\hline $\mathbf{2 4}$ & 115 & 147 & 44 & 101 & 73 & 19 & 10 \\
\hline $\mathbf{2 5}$ & 103 & 76 & 74 & 95 & 46 & 20 & 52 \\
\hline $\mathbf{2 6}$ & 71 & 52 & 77 & 102 & 84 & 67 & 47 \\
\hline $\mathbf{2 7}$ & 54 & 13 & 46 & 95 & 46 & 78 & 73 \\
\hline $\mathbf{2 8}$ & 14 & 23 & 32 & 76 & 138 & 307 & 126 \\
\hline $\mathbf{2 9}$ & 90 & 109 & 85 & 115 & 94 & 35 & 28 \\
\hline $\mathbf{3 0}$ & 65 & 139 & 122 & 186 & 158 & 55 & 54 \\
\hline MÉ DIA & $\mathbf{7 7}$ & $\mathbf{8 4}$ & $\mathbf{7 2}$ & $\mathbf{1 1 0}$ & $\mathbf{8 4}$ & $\mathbf{7 6}$ & $\mathbf{6 0}$ \\
\hline
\end{tabular}

Para melhor análise da espessura de película, os pontos analisados foram agrupados, segundo a figura 5.1, em regiões na seguinte ordem: região I - média dos pontos $A$ e $G$, região II - média dos pontos $B$ e $F$, região III - média dos pontos $\mathrm{C}$ e $\mathrm{E}$ e região IV - ponto D. Desta forma, este agrupamento gerou as tabelas 5.9 (grupo $\mathrm{MC}$ ), 5.10 (grupo IZ) e 5.11 (grupo PZ), apresentadas a seguir.

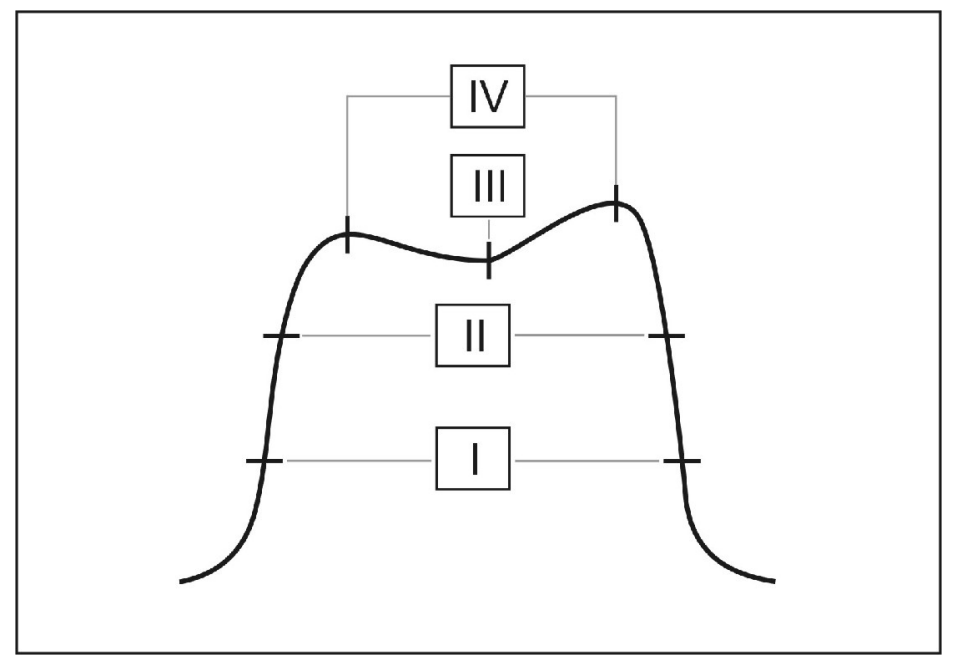

FIGURA 5.1 - ilustração das regiões correspondentes a região axio-cervical (I), axio-oclusal (II), porção superior das cúspides (III) e porção inferior do sulco mesio-distal (IV) 
TABELA 5.9 - Médias de espessura de película $(\mu \mathrm{m})$ nas regiões I, II, III e IV das i.es. metálicas para metalo-cerâmica.

\begin{tabular}{|c|c|c|c|c|}
\hline & \multicolumn{5}{|c|}{ GRUPO MC } \\
\hline $\mathbf{0 1}$ & I & II & III & IV \\
\hline $\mathbf{0 2}$ & 96 & 19 & 63 & 117 \\
\hline $\mathbf{0 3}$ & $\mathbf{7 8}$ & 12 & 43 & 68 \\
\hline $\mathbf{0 4}$ & 120 & 12 & 40 & 68 \\
\hline $\mathbf{0 5}$ & 100 & 19 & 60 & 78 \\
\hline $\mathbf{0 6}$ & 29 & 15 & 65 & 89 \\
\hline $\mathbf{0 7}$ & 74 & 11 & 56 & 59 \\
\hline $\mathbf{0 8}$ & 51 & 17 & 89 & 131 \\
\hline $\mathbf{0 9}$ & 79 & 14 & 26 & 23 \\
\hline $\mathbf{1 0}$ & 80 & 10 & 74 & 88 \\
\hline MÉDIA & $\mathbf{7 7}$ & $\mathbf{1 7}$ & $\mathbf{5 7}$ & $\mathbf{8 1}$ \\
\hline
\end{tabular}

TABELA 5.10 - Médias de espessura de película $(\mu \mathrm{m})$ nas regiões I, II, III e IV das i.es. cerâmicas do sistema In-Ceram Zirconia.

\begin{tabular}{|c|c|c|c|c|}
\hline & \multicolumn{3}{|c|}{ GRUPO IZ } \\
\hline $\mathbf{1 1}$ & $\mathbf{I}$ & II & III & IV \\
\hline $\mathbf{1 2}$ & 51 & 76 & 61 & 79 \\
\hline $\mathbf{1 3}$ & 64 & 82 & 75 & 58 \\
\hline $\mathbf{1 4}$ & 70 & 50 & 40 & 61 \\
\hline $\mathbf{1 5}$ & 72 & 63 & 44 & 80 \\
\hline $\mathbf{1 6}$ & 135 & 58 & 66 & 86 \\
\hline $\mathbf{1 7}$ & 108 & 68 & 54 & 49 \\
\hline $\mathbf{1 8}$ & 147 & 95 & 25 & 61 \\
\hline $\mathbf{1 9}$ & 102 & 90 & 64 & 116 \\
\hline $\mathbf{2 0}$ & 67 & 59 & 53 & 107 \\
\hline MÉDIA & $\mathbf{8 8}$ & $\mathbf{7 0}$ & $\mathbf{5 5}$ & $\mathbf{7 3}$ \\
\hline
\end{tabular}


TABELA 5.11 - Médias de espessura de película $(\mu \mathrm{m})$ nas regiões I, II, III e IV das i.es. cerâmicas do sistema Procera AllZircon.

\begin{tabular}{|c|c|c|c|c|}
\hline \multicolumn{5}{|c|}{ GRUPO P - i.e. Procera AllZircon } \\
\hline & I & II & III & IV \\
\hline $\mathbf{2 1}$ & 77 & 73 & 41 & 117 \\
\hline $\mathbf{2 2}$ & 82 & 81 & 62 & 118 \\
\hline $\mathbf{2 3}$ & 74 & 80 & 119 & 99 \\
\hline $\mathbf{2 4}$ & 63 & 83 & 59 & 101 \\
\hline $\mathbf{2 5}$ & 78 & 48 & 60 & 95 \\
\hline $\mathbf{2 6}$ & 59 & 60 & 81 & 102 \\
\hline $\mathbf{2 7}$ & 64 & 46 & 46 & 95 \\
\hline $\mathbf{2 8}$ & 70 & 165 & 85 & 76 \\
\hline $\mathbf{2 9}$ & 59 & 72 & 90 & 115 \\
\hline $\mathbf{3 0}$ & 60 & 97 & 140 & 186 \\
\hline MÉDIA & $\mathbf{6 9}$ & $\mathbf{8 1}$ & $\mathbf{7 8}$ & $\mathbf{1 1 0}$ \\
\hline
\end{tabular}

\section{4 - ANÁLISE ESTATÍSTÍCA}

\subsection{1 - desajuste vertical}

A tabela 5.12 traz a média de desajuste vertical por face, após a simulação da cimentação das i.es., e respectivo desvio-padrão, para cada grupo.

Para o desajuste vertical, quando utilizada Análise de Variância a 2 critérios (grupo de coroa e face medida), houve diferença estatisticamente significante entre os grupos $(F=6,48 ; p=0,005)$ e entre as faces medidas $(F=9,05 ; p<0,001)$. Porém, não houve interação $(F=2,12 ; p=0,0592)$, ou seja, independentemente do grupo observado, ocorreu diferença estatística significante entre as faces. Da mesma forma, independentemente da face observada, ocorreu diferença estatística significante entre os grupos. 
TABELA 5.12 - Desajuste vertical médio por face $(\mu \mathrm{m})$ e respectivo desvio-padrão (dp).

\begin{tabular}{|c|c|c|c|c|c|c|}
\hline GRUPO & $\mathbf{V}$ & $\mathbf{L}$ & $\mathbf{M}$ & $\mathbf{D}$ & MÉDIA & \multirow{2}{*}{$\begin{array}{c}\text { NÚMERO DE } \\
\text { ESPÉCIMES }\end{array}$} \\
\hline MC & $-14(23)$ & $11(34)$ & $-9(22)$ & $-6(23)$ & $-\mathbf{4}(\mathbf{2 6})$ & 10 \\
\hline IZ & $-8(20)$ & $13(12)$ & $15(18)$ & $2(12)$ & $\mathbf{6 ( 1 6 )}$ & 10 \\
\hline PZ & $-51(27)$ & $13(39)$ & $-24(40)$ & $-2(38)$ & $-\mathbf{1 6 ( 3 6 )}$ & 10 \\
\hline MÉDIA & $-\mathbf{2 4}(\mathbf{3 0}$ & $\mathbf{1 3}(\mathbf{3 0})$ & $\mathbf{- 6 ( 3 2 )}$ & $\mathbf{- 2 ( 2 6 )}$ & & $\mathbf{3 0}$ \\
\hline
\end{tabular}

Utilizando o teste de Tukey para a média do desajuste vertical após a cimentação: a) por grupo, observou-se que o grupo $\mathrm{PZ}$ foi diferente estatisticamente do grupo IZ e o grupo MC semelhante ao grupo IZ e ao grupo PZ; b) por face, observou-se que a face vestibular foi diferente das faces distal e lingual e semelhante à face mesial, não havendo diferença estatística significante entre as faces lingual, mesial e distal. (tabelas 5.13 e 5.14).

TABELA 5.13 - Teste de Tukey comparando desajuste vertical por grupo $(\mu \mathrm{m})$.

\begin{tabular}{|c|c|}
\hline GRUPO & MÉDIA \\
\hline MC & $-4^{\mathbf{a b}}$ \\
\hline IZ & $6^{\mathbf{b}}$ \\
\hline PZ & $-16^{\mathbf{a}}$ \\
\hline
\end{tabular}

OBS: médias assinaladas com a mesma letra não possuem diferença estatística entre si

TABELA 5.14 - Teste de Tukey comparando desajuste vertical por face $(\mu \mathrm{m})$.

\begin{tabular}{|c|c|}
\hline FACE & MÉDIA \\
\hline V & $-24^{\mathbf{a}}$ \\
\hline L & $13^{\mathbf{b}}$ \\
\hline M & $-6^{\mathbf{a b}}$ \\
\hline$D$ & $-2^{\mathbf{b}}$ \\
\hline
\end{tabular}

OBS: médias assinaladas com a mesma letra não possuem diferença estatística entre si 


\subsection{2 - espessura de película}

As tabelas 5.6, 5.7 e 5.8 foram submetidas à análise estatística, gerando inicialmente, um resumo descritivo com média de espessura, valores mínimo e máximo e desvio-padrão por ponto (tabelas 5.15, 5.16 e 5.17, respectivamente para os grupos MC, IZ e PZ), bem como sua representação gráfica (figura 5.2). Isto torna visível a grande variabilidade na espessura de película encontrada por ponto, entre as i.es. Por exemplo, na tabela 5.17 , no ponto $F$, foi possível encontrar espessura igual a $18 \mu \mathrm{m}$ e a $307 \mu \mathrm{m}$, demonstrando uma amplitude de $289 \mu \mathrm{m}$.

TABELA 5.15 - Resumo descritivo da espessura de película $(\mu \mathrm{m})$ por ponto, nas i.es. metálicas para metalo-cerâmica.

\begin{tabular}{|c|c|c|c|c|}
\hline PONTO & MÉDIA & MíNIMO & MÁXIMO & DESVIO-PADRÃO \\
\hline A & 64 & 20 & 122 & 31 \\
\hline B & 18 & 7 & 43 & 10 \\
\hline C & 54 & 31 & 83 & 20 \\
\hline D & 79 & 23 & 131 & 31 \\
\hline E & 59 & 16 & 100 & 28 \\
\hline F & 15 & 10 & 34 & 7 \\
\hline G & 90 & 37 & 132 & 27 \\
\hline
\end{tabular}

TABELA 5.16 - Resumo descritivo da espessura de película ( $\mu \mathrm{m})$ por ponto, nas i.es. cerâmicas do sistema In-Ceram Zirconia.

\begin{tabular}{|c|c|c|c|c|}
\hline PONTO & MÉDIA & MÍNIMO & MÁXIMO & DESVIO-PADRÃO \\
\hline A & 100 & 59 & 161 & 100 \\
\hline B & 63 & 43 & 139 & 63 \\
\hline C & 60 & 28 & 105 & 60 \\
\hline D & 73 & 37 & 116 & 73 \\
\hline $\mathbf{E}$ & 49 & 20 & 68 & 49 \\
\hline $\mathbf{F}$ & 71 & 25 & 124 & 71 \\
\hline $\mathbf{G}$ & 76 & 38 & 141 & 76 \\
\hline
\end{tabular}


TABELA 5.17 - Resumo descritivo da espessura de película $(\mu \mathrm{m})$ por ponto, em i.es. cerâmicas do sistema Procera AllZircon.

\begin{tabular}{|c|c|c|c|c|}
\hline PONTO & MÉDIA & MíNIMO & MÁXIMO & DESVIO-PADRÃO \\
\hline A & 77 & 14 & 128 & 37 \\
\hline B & 84 & 13 & 147 & 51 \\
\hline C & 72 & 23 & 189 & 51 \\
\hline D & 110 & 76 & 186 & 29 \\
\hline E & 84 & 46 & 158 & 39 \\
\hline F & 76 & 18 & 307 & 87 \\
\hline G & 60 & 10 & 126 & 37 \\
\hline
\end{tabular}

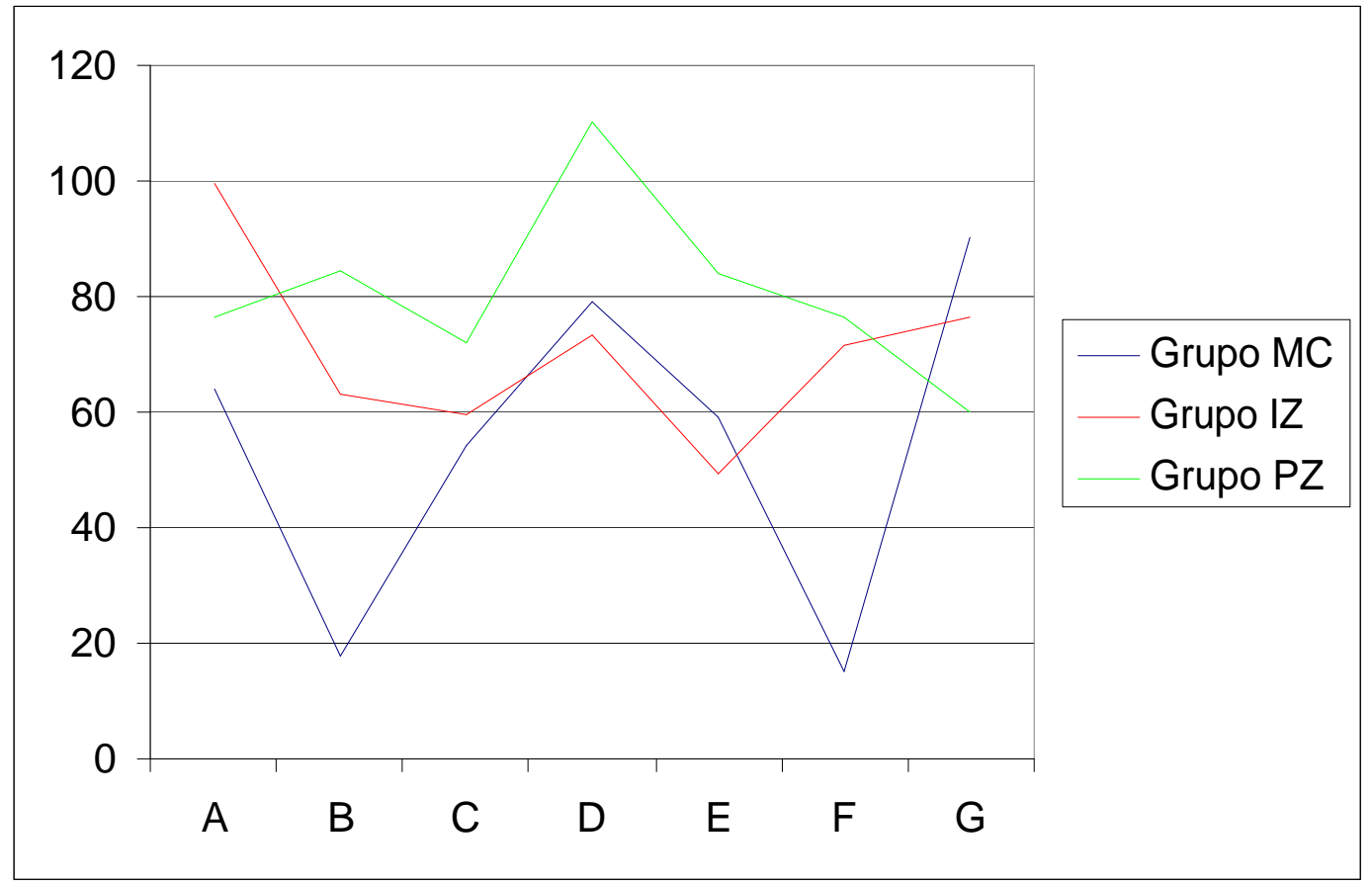

FIGURA 5.2 - representação gráfica da média de espessura dos grupos MC, IZ e PZ por ponto

A tabela 5.18 traz a espessura média de película para cada grupo e entre os grupos para as regiões I, II, III e IV (agrupamento segundo figura 5.1) e o respectivo desvio-padrão (dp). 
Para espessura de película, quando utilizada Análise de Variância a 2 critérios (grupo de coroa e região de medição), houve diferença estatisticamente significante entre os grupos $(F=9,57 ; p<0,001)$ e entre as regiões medidas $(F=11,53 ; p<0,001)$. Houve, também, interação entre grupos e região de medição $(F=6,66 ; p<0,001)$, ou seja, a diferença estatisticamente significante ocorreu em diferentes localizações da película e diferentes tipos de coroas. Necessariamente, não houve diferenças entre os grupos em todas as regiões mensuradas, bem como, nem todas as regiões foram diferentes em todos os grupos.

TABELA 5.18 - Espessura média de película para cada grupo e entre os grupos para cada região $(\mu \mathrm{m})$ e respectivo desvio-padrão $(\mathrm{dp})$.

\begin{tabular}{|c|c|c|c|c|}
\hline \multirow{2}{*}{ GRUPO } & \multicolumn{4}{|c|}{ REGĨ̃O } \\
\hline MC & $\mathbf{I}$ & $\boldsymbol{I I}$ & $\mathbf{I I I}$ & $\mathbf{I V}$ \\
\hline $\mathbf{I Z}$ & $87(25)$ & $17(8)$ & $57(18)$ & $81(30)$ \\
\hline PZ & $69(3)$ & $70(15)$ & $55(15)$ & $73(25)$ \\
\hline $\begin{array}{c}\text { média dos } \\
\text { grupos }\end{array}$ & $\mathbf{7 8 ( 2 5 )}$ & $81(34)$ & $78(32)$ & $110(29)$ \\
\hline
\end{tabular}

Utilizando o teste de Tukey para comparar os grupos, levando em consideração as regiões de medição, observou-se que, para a região I, não houve diferença estatística significante na espessura de película entre os grupos. Para a região II, o grupo MC apresentou estatisticamente menor espessura de película que os grupos IZ e $\mathrm{PZ}$, que apresentaram valores semelhantes entre si. Para a região III, também não houve diferença significante na espessura de película entre os grupos. Para a região IV, o grupo IZ apresentou estatisticamente menor espessura de película que o grupo PZ; entretanto, o grupo MC foi semelhante ao grupo IZ e ao grupo PZ (tabela 5.19). 
TABELA 5.19 - Teste de Tukey comparando grupos, considerando as regiões I, II, III e IV.

\begin{tabular}{|c|c|c|c|c|}
\hline GRUPO & Região I & Região II & Região III & Região IV \\
\hline MC & $77^{\mathbf{a}}$ & $17^{\mathbf{a}}$ & $57^{\mathbf{a}}$ & $81^{\mathbf{a} / \mathbf{b}}$ \\
\hline IZ & $88^{\mathbf{a}}$ & $70^{\mathbf{b}}$ & $55^{\mathbf{a}}$ & $73^{\mathbf{a}}$ \\
\hline $\mathbf{P Z}$ & $69^{\mathbf{a}}$ & $81^{\mathbf{b}}$ & $78^{\mathbf{a}}$ & $110^{\mathbf{b}}$ \\
\hline
\end{tabular}

OBS: médias assinaladas com a mesma letra não possuem diferença estatística entre si para a mesma região

Quando o teste de Tukey foi utilizado para comparação entre as regiões de medição, levando em consideração os grupos, observou-se que para o grupo MC, a região II produziu espessura de película estatisticamente significante menor que as demais regiões; entre as regiões I, III e IV, não houve diferença estatística significante. Para o grupo IZ, a região III apresentou espessura significantemente menor que a região I; entre as regiões I, II e IV, não houve diferença estatística significante, bem como não houve diferença significante entre as regiões II, III e IV. Para o grupo PZ, a região I e a região III mostraram espessura de película significantemente menor que a região IV; porém, entre as regiões I, II e III, não houve diferença estatística significante, bem como não houve diferença significante entre as regiões II e IV (tabela 5.20).

TABELA 5.20 - Teste de Tukey comparando regiões, considerando os grupos MC, IZ e PZ.

\begin{tabular}{|c|c|c|c|}
\hline REGIÃO & Grupo MC & Grupo IZ & Grupo PZ \\
\hline I & $77^{\mathbf{a}}$ & $88^{\mathbf{a}}$ & $69^{\mathbf{a}}$ \\
\hline II & $17^{\mathbf{b}}$ & $70^{\mathbf{a} / \mathbf{b}}$ & $81^{\mathbf{a} / \mathbf{b}}$ \\
\hline III & $57^{\mathbf{a}}$ & $55^{\mathbf{b}}$ & $78^{\mathbf{a}}$ \\
\hline IV & $81^{\mathbf{a}}$ & $73^{\mathbf{a} / \mathbf{b}}$ & $110^{\mathbf{b}}$ \\
\hline
\end{tabular}

OBS: médias assinaladas com a mesma letra não possuem diferença estatística entre si para o mesmo grupo 
A tabela 5.21 mostra a espessura média de película de cada grupo e entre os grupos e o respectivo desvio-padrão. Estes valores foram obtidos pela média das regiões I, II, III e IV para cada grupo.

TABELA 5.21 - Espessura média de película para cada grupo e entre os grupos $(\mu \mathrm{m})$ e respectivo desvio-padrão (dp).

\begin{tabular}{|c|c|c|}
\hline GRUPO & MÉDIA (dp) & NÚMERO DE ESPÉCIMES \\
\hline MC & $58(13)$ & 10 \\
\hline IZ & $71(10)$ & 10 \\
\hline PZ & $84(17)$ & 10 \\
\hline $\begin{array}{c}\text { média entre } \\
\text { os grupos }\end{array}$ & $\mathbf{7 1 ( 1 7 )}$ & $\mathbf{3 0}$ \\
\hline
\end{tabular}

Ponderando a espessura média de película de cada grupo, a análise de variância a 1 critério demonstrou diferença estatística entre os grupos ( $F=9,57$; $\mathrm{p}<0,001)$. O teste de Tukey apontou a espessura de película do grupo MC, como estatisticamente menor do que aquela do grupo PZ; entretanto, o grupo MC apresentou espessura semelhante ao grupo IZ e o grupo IZ apresentou película semelhante ao grupo PZ (tabela 5.22).

TABELA 5.22 - Teste de Tukey comparando espessura média de película entre os grupos $(\mu \mathrm{m})$.

\begin{tabular}{|c|c|}
\hline GRUPO & MÉDIA \\
\hline MC & $58^{\mathbf{a}}$ \\
\hline IZ & $71^{\mathbf{a} / \mathbf{b}}$ \\
\hline PZ & $84^{\mathbf{b}}$ \\
\hline
\end{tabular}

OBS: médias assinaladas com a mesma letra não possuem diferença estatística entre si 
Para se verificar a correlação entre espessura de película e desajuste vertical foi utilizado o coeficiente de correlação de Pearson, obtendo-se $r=-0,26 ; p=0,173$, sendo 0 resultado estatisticamente não significante (figura 5.3).

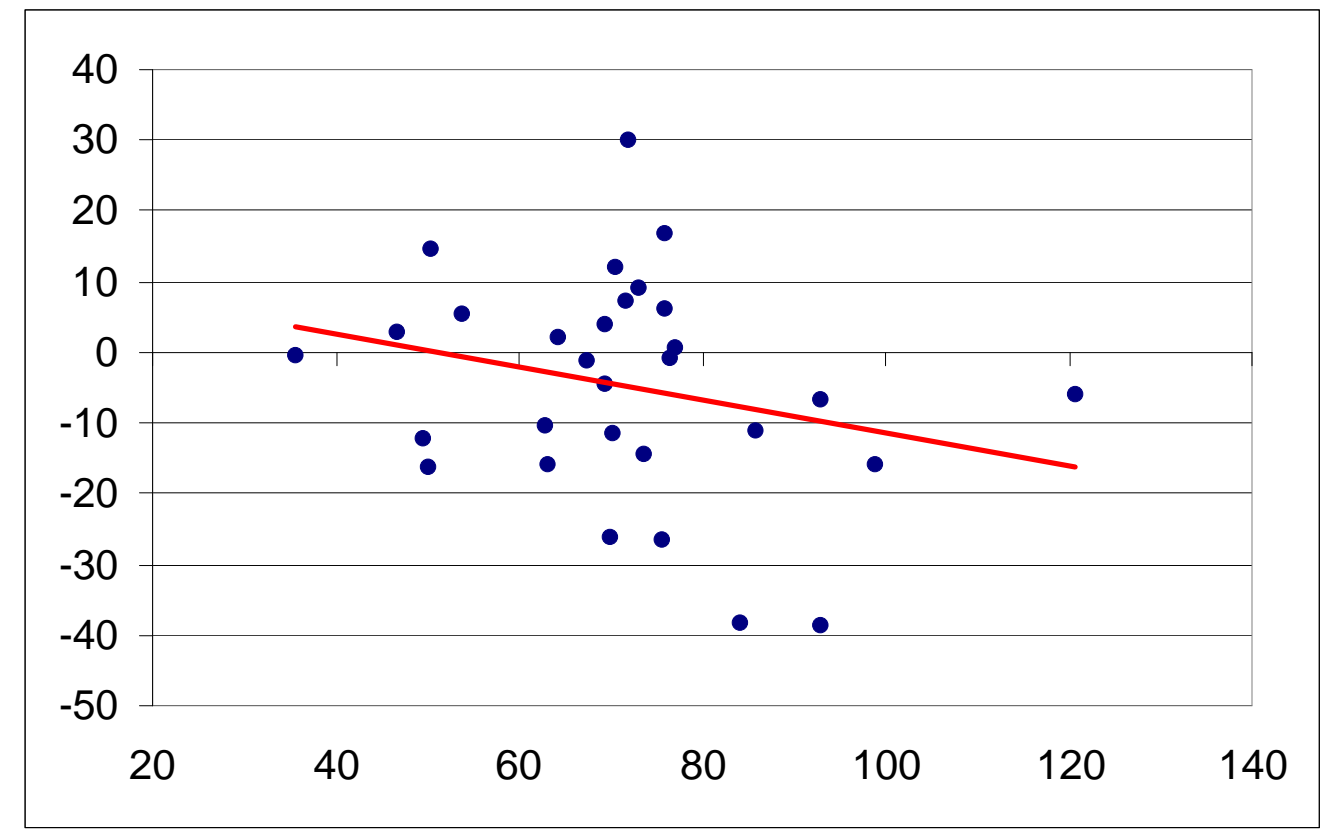

FIGURA 5.3 - representação gráfica da correlação entre espessura de película e desajuste vertical segundo o coeficiente de correlação de Pearson $(r=-0,26 ; p=0,173)$ 


\section{DISCUSSÃO}

O processo de fundição por cera perdida, introduzido por TAGGART ${ }^{84}$, em 1907, certamente foi um dos maiores passos para o avanço das técnicas odontológicas. Este processo é apontado, até hoje, como o grande responsável pela produção de restaurações de ajuste preciso, que estejam de acordo com a concepção atual de fisiologia, função, mecânica e estética.

Durante as últimas décadas, o uso de ligas básicas, em substituição às ligas de ouro, ganhou grande espaço, impulsionado, principalmente, pela vantagem financeira trazida pela substituição. A consagração das restaurações metálicas indiretas, conseguida através dos anos, fundamenta-se nos resultados clínicos favoráveis relatados na literatura e evidenciado por clínicos em todo o mundo. Desta forma, é inevitável que qualquer sistema inovador que venha a ser apresentado como substituto do metal, deva ser comparado a este padrão.

Concomitantemente, o desenvolvimento de novos sistemas cerâmicos com reforço de alumina e zircônio impulsionou o mercado dos fabricantes de materiais odontológicos, alimentando o desejo daqueles profissionais ávidos em utilizar restaurações indiretas sem a presença de metal.

A adaptação de uma coroa, tradicionalmente, refere-se ao espaço existente entre sua superfície interna e o dente preparado, embora seja a adaptação alcançada após sua cimentação, o mais relevante fator para a longevidade da restauração (HOLLENBACK ${ }^{37}$, 1928). HOLMES ${ }^{38}$ (1989) acreditava que a adaptação de uma coroa pudesse ser mais bem definida em termos de "desajuste" mensurado em diversos pontos entre a superfície interna daquela e o dente preparado. O crescente interesse 
por restaurações indiretas cerâmicas trouxe à tona a necessidade de se identificar fatores significantes ao sucesso clínico dos materiais e, idealmente, informação suficiente para predizer seu comportamento ao longo do tempo. Entretanto, informações objetivas a respeito do ajuste de uma coroa não são fáceis de serem obtidas. A problemática de se mensurar a adaptação tridimensional de restaurações indiretas ainda não está resolvida na prática (QUALTROUGH; PIDDOCK ${ }^{70}$, 1992).

As técnicas de obtenção das i.es. deste trabalho são consideravelmente influenciadas pelos fenômenos de contração e expansão de cada um dos materiais utilizados nestes processos. Características intrínsecas dos materiais de moldagem, produtos à base de gesso e revestimento, plásticos, ceras, massas cerâmicas e ligas metálicas fazem com que, geralmente, as i.es. obtidas por estas técnicas, não se adaptem precisamente aos preparos dentais que as deram origem. Estas distorções nas i.es. fazem com que exista um espaço interno não uniforme que influenciaria sua completa adaptação. FUSAYAMA et al. ${ }^{28}$ (1963) observaram que mesmo sem cimento, as restaurações metálicas fundidas não se assentavam completamente, devido às numerosas variáveis associadas ao processo de fundição. Além disso, este espaço interno não uniforme, ainda levaria a um inapropriado fluxo de escoamento durante a cimentação, com conseqüente desajuste marginal, oclusal e proximal da restauração. (DAVIS; KELLY; CAMPBELL $\left.{ }^{18}, 1989\right)$. O íntimo contato entre as paredes das i.es. e do preparo dental pode ser desfavorável à retenção das coroas e favorecer o processo de filtragem do agente de cimentação, como descrito por JØRGENSEN ${ }^{42,43}$, em 1960a e 1960b. Quanto mais justo for o contato entre a coroa e o dente, mais difícil é o escoamento do cimento entre as paredes do preparo e da restauração (SCHWARTZ ${ }^{77}$, 1986).

O conceito de que uma 'boa fundição' deveria adaptar-se de forma justa ao preparo tem sido questionado há alguns anos por autores que não encontraram 
correlação significativa entre retenção das coroas antes e após a cimentação (GRAJOWER; LEWINSTEIN ${ }^{31}, 1983$, SCHWARTZ77 1986 e MARKER et al. ${ }^{54}, 1987$ ). A retenção antes da cimentação pode ser devida a discrepâncias na superfície interna da coroa, como bolhas, nódulos ou elevada rugosidade superficial.

As i.es. utilizadas neste trabalho não receberam adição de porcelana de recobrimento e isso, segundo PERA et al. ${ }^{63}$ (1994) e SHEARER; GOUGH; SETCHELL ${ }^{78}$ (1996), não influenciaria os resultados obtidos nas diversas avaliações experimentais da pesquisa.

Este trabalho avaliou a influência do ajuste interno de i.es. adaptadas sobre um troquel-padrão metálico. Um silicone de consistência fluida foi utilizado como agente revelador de contatos internos, como proposto por ARAKELIAN ${ }^{4}$ (1982), RISSIN; WETREICH $^{72}$ (1983), DAVIS; KELLY; CAMPBELL ${ }^{18}$ (1989), WHITE; SORENSEN; KANG $^{90}$ (1991), TROENDLE; TROENDLE; CAVAZOS ${ }^{86}$ (1991) WHITE; KIPNIS ${ }^{89}$ (1993) e KEYS ${ }^{52}$ (2002). Quando colocado no interior da i.e. e assentada sobre o preparo dental, o material forma uma réplica tridimensional do espaço interno da restauração. Áreas que revelem de forma direta ou por transparência a superfície interna das i.es. devem ser ajustadas, até que se forme uma película uniforme de silicone sob as mesmas. Uma vantagem de se utilizar um elastômero como ferramenta de ajuste interno é o fato do operador poder fazer avaliação visual e qualitativa da adaptação geral da coroa. As observações de DAVIS; KELLY; CAMPBELL ${ }^{18}$ (1989) indicaram espessura de película de cimento mais uniforme para coroas ajustadas internamente, do que para coroas que não sofreram qualquer ajuste.

Outro motivo para o silicone fluido ter sido utilizado como revelador de contatos internos, é o fato de que este mesmo material foi usado como cimento-análogo na avaliação da espessura de película das i.es. Desta forma, o ajuste interno propiciou espaço suficiente para a acomodação deste material. Se o ajuste fosse realizado 
através de outro agente evidenciador de contatos, talvez o espaço criado pelo ajuste não fosse compatível com a espessura de película do cimento-análogo. Logo, a análise do espaço interno das i.es. poderia sofrer ainda mais influência da dinâmica dos fluidos, durante a cimentação.

Os resultados obtidos na adaptação das i.es. demonstraram a efetividade deste procedimento. Os grupos ajustados (MC e IZ) tiveram redução média de 55,4 $\mu \mathrm{m}$ e $17 \mu \mathrm{m}$, respectivamente, após a adaptação de seus corpos de prova sobre o troquelpadrão (tabelas 5.1 e 5.2). Estes resultados são semelhantes aos encontrados por USHIWATA et al. ${ }^{87}$ (2000), que observaram melhora na adaptação de i.es. metálicas fundidas em liga de níquel-cromo, em $51,5 \mu \mathrm{m}$, sobre troquéis de gesso. Da mesma forma, DAVIS; KELLY; CAMPBELL ${ }^{18}$ (1989) também observaram melhora na adaptação de coroas de ouro em $61 \mu \mathrm{m}$. Estes valores superaram outros resultados encontrados na literatura. WHITE; SORENSEN; KANG ${ }^{90}$ (1991) e WHITE; KIPNIS ${ }^{89}$ (1993) encontraram redução média no desajuste marginal de $37 \mu \mathrm{m}$ e $10 \mu \mathrm{m}$, respectivamente, para coroas fundidas em liga básica.

Embora todas as i.es. se apresentassem adequadamente adaptadas nos troquéis de gesso, todos os espécimes dos grupos MC e IZ receberam de uma a três seqüências de ajuste interno (da maneira descrita na seção Material e Métodos deste trabalho), com exceção do corpo de prova número 5 do grupo MC que necessitou ser ajustado 6 vezes. Isto resultou no maior valor médio de adaptação das i.es. (223 $\mu \mathrm{m}$ tabela 5.1). Entretanto, isto não fez com que este espécime tivesse um comportamento diferente dos demais na avaliação do desajuste vertical e da espessura de película, como pode ser observado nas tabelas 5.3 e 5.6. A avaliação da película do silicone fluido revelou que nenhuma das i.es. do grupo PZ necessitaria de ajuste de sua superfície interna. 
HOBKIRK $^{36}$ (1977) afirmou que o desgaste interno das i.es. deveria ser evitado, pois os procedimentos de abrasão afetariam a textura superficial e, conseqüentemente, a resistência do material.

Este experimento utilizou um único troquel-padrão metálico com dimensões semelhantes às de um dente natural, limite cervical bem definido e superfície polida e regular. Como em situações clínicas os preparos dentais tendem a ser mais irregulares, talvez os resultados do ajuste interno assim obtidos possam ser maiores do que aqueles conseguidos neste estudo.

A literatura odontológica acerca dos sistemas cerâmicos parece considerar desajustes marginais na ordem de 100 a $200 \mu \mathrm{m}$ como aceitáveis (SULAIMAN et al. ${ }^{82}$, 1997, NEIVA et al. ${ }^{58}, 1998$, BOENING et al. ${ }^{9}, 2000$ e ÖDMAN; ANDERSSON ${ }^{59}, 2001$ ). Entretanto, aqueles autores que discorreram sobre i.es. metálicas relataram que o desajuste tolerável seria de 25 a $50 \mu \mathrm{m}$ (JØRGENSEN ${ }^{42}$, 1960a, FUSAYAMA; IWAMOTO $^{27}, 1961$ e CHRISTENSEN $\left.{ }^{17}, 1971\right)$. Ou ainda não existe um consenso a respeito do limite aceitável de desajuste ou existe uma complacência quanto ao desajuste de coroas totalmente cerâmicas, frente às limitações inerentes de seus sistemas.

Desde muito tempo credita-se à dificuldade de escoamento do cimento como o principal fator que impede o assentamento completo de uma coroa total, já que à medida que a coroa se assenta, a área marginal de escape para o cimento diminui, dificultando o escoamento pelo estreitamento do caminho de saída. Muitos estudos se propuseram a solucionar este inconveniente, avaliando pressão de cimentação (JøRGENSEN ${ }^{42}$, 1960 $0^{\text {a }}$ e ISHIKIRIAMA et al. ${ }^{40}, 1981$ ), duração da pressão de cimentação (JøRGENSEN $\left.{ }^{42}, 1960 a\right)$, proporção pó/líquido (JøRGENSEN ${ }^{42}$, 1960a e WINDELER ${ }^{98}$, 1979), geometria do preparo (FUSAYAMA et al. ${ }^{28}, 1963$, KAY; 
JABLONSKI; DOGON ${ }^{49}, 1986$, BYRNE $^{11}, 1992$ e SYU et al. ${ }^{83}$, 1993), tipo de cimento (EAMES et al. ${ }^{23}, 1978$ e HEMBREE; GEORGE; HEMBREE ${ }^{34}$, 1978), volume do cimento colocado (ISHIKIRIAMA et al. ${ }^{40}, 1981$ e TAN; IBBETSON ${ }^{85}$, 1996), perfuração na coroa para escoamento do cimento (JØRGENSEN ${ }^{42}, 1960 a$, BASSET ${ }^{6}$, 1966, HEMBREE; GEORGE; HEMBREE ${ }^{34}, 1978$ e ISHIKIRIAMA et al. $\left.{ }^{40}, 1981\right)$, uso de espaçadores de troquéis (EAMES et al. ${ }^{23}, 1978$ e WILSON $\left.{ }^{96}, 1994\right)$ e alívio interno da superfície das coroas com tratamentos químico e mecânico (HOLLENBACK ${ }^{37}$, 1928 e BASSET $^{6}$, 1966).

Este trabalho avaliou a influência da cimentação sobre o desajuste vertical das i.es., que foram cimentadas sob pressão digital, como sugerido por DAVIS; KELLY; CAMPBELL $^{18}$ (1989) e mantidas em posição sob $2 \mathrm{Kg}$ de carga. A cimentação foi assim realizada para aproximar o procedimento laboratorial da situação clínica, além de que as i.es. correriam risco de fratura se submetidas à carga maior (WEAVER; JOHNSON; BALES $^{88}$, 1991, MAY et al. ${ }^{55}, 1998$ e QUINTAS; OLIVEIRA; BOTTINO ${ }^{71}$, 2004). WILSON et al. ${ }^{94}$ (1990) sugeriram que coroas totalmente cerâmicas fossem cimentadas sob baixa carga de assentamento (por volta de 0,3 a $1 \mathrm{Kg}$ ), com cimentos de baixa viscosidade e afirmaram que cargas exageradas poderiam aumentar a transmissão de pressão em direção à polpa, aumentando a possibilidade de injúria.

A simulação da cimentação sempre resultou em desajuste. As coroas assumiram uma posição espacial, em relação ao troquel-padrão, distinta daquela que tinham na ausência do cimento-análogo, fazendo crer que a presença do agente de cimentação é capaz de produzir variação vertical na posição das coroas. As i.es. do grupo IZ desajustaram, em média, $6 \mu \mathrm{m}$ (tabela 5.4), enquanto as dos grupos MC e PZ sobre-assentaram-se $-4 \mu \mathrm{m}$ e $-16 \mu \mathrm{m}$, respectivamente (tabelas 5.3 e 5.5 ). $O$ teste de Tukey (tabela 5.13) demonstrou que o grupo PZ foi diferente estatisticamente do grupo 
IZ e o grupo MC semelhante ao grupo $I Z$ e ao grupo PZ. Inúmeros autores (JøRGENSEN ${ }^{42}$, 1960a, FUSAYAMA et al. ${ }^{28}$, 1963, BASSET $^{6}$, 1966, BOLOURI; MARKER; SARAMPOTE ${ }^{10}$, 1987, ROSENSTIEL; GEGAUFF ${ }^{73}$, 1988, GEGAUFF; ROSENSTIEL ${ }^{29}, 1989$, KERN; SCHALLER; STRUB ${ }^{51}, 1993$, WHITE; KIPNIS ${ }^{89}, 1993$, TAN; IBBETSON ${ }^{85}$, 1996, BESCHNIDT; STRUB ${ }^{7}, 1999$ e QUINTAS; OLIVEIRA; BOTTINO $^{71}$, 2004) observaram desajuste vertical após a cimentação de coroas totais.

A conseqüência da abertura marginal, causada pelo desajuste vertical após a cimentação, é o aumento da área de cimento exposto na margem. O papel da retenção de placa bacteriana na etiologia da cárie e inflamação gengival já foi estabelecido de forma bastante clara $\left(\right.$ SCHWARTZ $^{76}, 1970$, SORENSEN ${ }^{79}, 1989$ e FELTON et al. ${ }^{24}$, 1991). Minimizando o grau de desajuste marginal, a superfície de cimento exposta ao meio oral também diminuirá, reduzindo a taxa de dissolução do cimento nos fluidos orais (KAWAI; ISENBERG; LEINFELDER ${ }^{48}$, 1993). Tanto quando o cimento é dissolvido, quanto durante a remoção de seu excesso, um hiato é criado na margem da restauração, sendo nicho de retenção bacteriana. Quando este desajuste encontra-se acima da gengiva marginal livre, a principal preocupação é a recidiva de cárie. Quando se localiza sub-gengival, inflamação gengival e lesões de cárie podem ocorrer (SORENSEN $\left.{ }^{80}, 1990\right)$.

O efeito do desajuste marginal sobre a doença periodontal foi examinado por FELTON et al. ${ }^{24}, 1991$. Ele pôde concluir que as desajustes marginais teriam maior efeito sobre a inflamação periodontal do que a localização do término cervical propriamente dita.

A existência de doença periodontal iatrogênica ao redor de coroas cerâmicas também está bem documentada (SORENSEN ${ }^{79}$, 1989). ÖDMAN; ANDERSSON ${ }^{59}$ (2001) observaram uma maior freqüência de sangramento à sondagem em dentes com 
coroas Procera AllCeram (39\%) do que em dentes naturais adjacentes (27\%). A fidelidade marginal de vários sistemas de coroas não é apenas uma preocupação acadêmica, mas de grande preocupação clínica, afetando a saúde e a estética do paciente.

McLEAN; von FRAUNHOFER ${ }^{57}$ (1971) mensuraram in vivo a espessura de película de coroas e demonstraram que o desajuste marginal variava de $10 \mu \mathrm{m}$ a 160 $\mu \mathrm{m}$. Também citaram o sucesso clínico, com 5 anos de acompanhamento, de mais de mil coroas com desajuste marginal da mesma ordem, sendo que, para eles, desajustes menores que $80 \mu \mathrm{m}$ seriam impossíveis de se detectar com uma sonda exploradora. Em 1999, BESCHNIDT; STRUB ${ }^{7}$ demonstraram, in vitro, que a ciclagem térmica e a carga cíclica não afetaram o desajuste marginal de coroas totais.

HOLLENBACK $^{37}$ (1928) e SCHWARTZ ${ }^{77}$ (1986) consideraram a adaptação marginal um fator primário e de valor extremamente significante na prevenção de cáries secundárias, além de um importante indicador da qualidade de uma coroa. Entretanto, em 1988, PILO et al. ${ }^{65}$ citaram terem encontrado pequena correlação clínica entre desajuste marginal e perda de cimento. Eles exemplificaram que coroas cimentadas por 8 a 15 anos, sobre dentes que tiveram de ser extraídos, apresentavam desajustes marginais grosseiros e nenhuma perda de cimento. Por outro lado, outras coroas com ajuste marginal considerado adequado exibiam significante degradação da linha de cimento, demonstrando que a integridade marginal pode não ser a única responsável pela perda do agente de cimentação.

CHRISTENSEN $^{16}$ (1966) observou que 10 experientes operadores não foram capazes de determinar, de forma correta e consistente, o desajuste marginal de áreas acessíveis exclusivamente por sonda exploradora e imagens radiográficas. Algumas destas foram consideradas satisfatórias com desajuste de até $119 \mu \mathrm{m}$. Entretanto, 
outras, onde o acesso visual e a percepção tátil com sonda exploradora eram possíveis, foram consideradas insatisfatórias com desajuste de $26 \mu \mathrm{m}$. DEDMON ${ }^{19}$ (1982) também encontrou ampla divergência de resultados inter e intra-examinadores, quando experientes profissionais avaliaram desajustes marginais horizontais e verticais. A média encontrada para desajustes verticais considerados inaceitáveis foi de $114 \mu \mathrm{m}$ e de $93 \mu \mathrm{m}$, para as horizontais.

QUINTAS; OLIVEIRA; BOTTINO ${ }^{71}$ (2004) cimentaram, sobre o mesmo troquel metálico, i.es. Procera AllCeram, InCeram Alumina e Empress 2 com os cimentos de fosfato de zinco, ionômero de vidro e resinoso. Os resultados mostraram que o tipo de agente de cimentação não foi significante quando considerado isoladamente. Entretanto, as i.es. do sistema Procera AllCeram apresentaram os menores valores médios de desajuste vertical após cimentação $(19 \mu \mathrm{m})$, quando comparadas àquelas dos sistemas Empress $2(42 \mu \mathrm{m})$ e In-Ceram Alumina (60 $\mu \mathrm{m})$.

Os resultados de CHAN et al. ${ }^{13}$ (2004) mostraram que quanto maior o grau de convergência das paredes do preparo, maior seria o desajuste vertical das coroas, sendo que a partir de $12^{\circ}$ de convergência, observou-se um decréscimo correspondente na retenção de coroas totais.

Para ROSENSTIEL; LAND; CRISPIN ${ }^{74}$ (1998) diferentes cimentos podem necessitar de diferentes espaços pré-cimentação. Estes afirmaram que a desajuste vertical da coroa, resultante da cimentação, existe em função da viscosidade do cimento. Tem sido demonstrado que cimentos resinosos resultam em significantemente maior incidência de desajuste vertical, presumidamente pela sua alta viscosidade (WHITE; YU; KIPNIS ${ }^{93}, 1992$ e WHITE; KIPNIS ${ }^{89}$, 1993). Entretanto, ainda não existem evidências claras de que um tipo de cimento possa promover melhor assentamento de coroas em relação aos demais. 
Não se pode esquecer que os agentes de união à dentina também têm uma espessura mensurável que pode atingir até $50 \mu \mathrm{m}$ nas paredes gengivais, axiais e oclusal. Entretanto, alguns agentes de união podem produzir espessura além de 200 $\mu \mathrm{m}$ nos ângulos axio-gengivais (de la MACORRA; PRADIES ${ }^{53}, 2002$ ).

EAMES et al. $^{23}$ (1978) notaram que houve diferença significante no assentamento de coroas, na ausência de cimento, quando a força de assentamento variou de pressão digital a força de mordida, com um efeito rebote entre $75 \mu \mathrm{m}$ e 150 $\mu \mathrm{m}$ após a remoção da força de mordida. O efeito rebote, para WILSON et al. ${ }^{94}(1990)$ e WILSON $^{95}$ (1992), não ocorre se a força for mantida sobre a coroa até que o cimento termine sua presa, implicando que haja um estresse residual no interior da mesma. Parece, ainda, não estar claro que efeitos este estresse residual teria sobre a estrutura do cimento e da coroa. HOARD et al. ${ }^{35}$ (1978) montaram três medidores de pressão no interior de um troquel metálico e avaliaram o comportamento da interface troquel/cimento. Eles observaram que a máxima pressão intracoronal mensurada acontecia após 2 segundos e reduzia até aproximadamente zero, após 1 minuto. Observaram também, que os cimentos menos viscosos produziram menor pressão durante o assentamento sobre o troquel, além de menor pressão residual. Desta forma, concluíram que a pressão hidráulica intracoronal pode ter um papel limitado no assentamento das coroas. HOARD et al. ${ }^{35}$ (1978) ainda sugeriram que o processo de filtragem postulado por JØRGENSEN ${ }^{43}$ (1960b), resultando no acúmulo de partículas de cimento em várias regiões da superfície interna das coroas, seria o responsável pelo aumento na espessura de película do cimento.

Foi demonstrado que um melhor assentamento das coroas pode ocorrer com o escoamento do cimento, durante a cimentação, através da área marginal ou perfuração oclusal. A existência de uma perfuração constitui-se, para as coroas cerâmicas, como 
um ponto de enfraquecimento da estrutura (WILSON $\left.{ }^{97}, 1996\right)$ e o reparo da perfuração torna-se, também, um fator de complicação do procedimento de cimentação (WILSON ${ }^{95}$, 1992). Técnicas como o pincelamento do cimento no interior das coroas (ISHIKIRIAMA et al. ${ }^{40}, 1981$ e TAN; IBBETSON $\left.{ }^{85}, 1996\right)$ foram propostas para permitir melhor assentamento das restaurações. A colocação de apropriado volume de cimento, para WILSON ${ }^{95}$ (1992), diminui a necessidade de canais oclusais de escape.

Este trabalho observou também que, para todas as i.es., o desajuste vertical não foi simétrico entre as faces. A interposição da película de silicone proporcionou a inclinação dos corpos de prova em relação ao troquel-padrão. Com freqüência, a inclinação fez com que estes apresentassem desajuste negativo (aproximação entre margem da i.e. e término cervical do preparo) em pelo menos uma das faces e desajuste positivo (distanciamento entre margem da i.e. e término cervical do preparo) nas demais. Nenhum corpo de prova apresentou apenas desajuste positivo. Em cinco deles (3 do grupo MC e 2 do grupo PZ), observou-se desajuste negativo em todas as faces. Entretanto, o assentamento foi assimétrico entre elas. Estes acontecimentos caracterizaram o assentamento oblíquo das i.es.

ROSENSTIEL; GEGAUFF ${ }^{73}$ (1988) explicaram o assentamento oblíquo descrevendo que a orientação das i.es. muda como resultado da imperfeita orientação da força de assentamento e do escape não uniforme do cimento. JØRGENSEN ${ }^{42}$ (1960a) afirmou que o fenômeno parecia ser uma inevitável conseqüência das condições hidrodinâmicas existentes quando duas superfícies cônicas, com líquido interposto entre elas, aproximavam-se. Ainda acrescentou que a inclinação do assentamento tendia a ser menos pronunciada quanto mais fina fosse a película de cimento. Além disso, diferentes métodos de aplicação de força de assentamento podem produzir diferentes proporções de assentamento oblíquo. PILO; CARDASH ${ }^{66}$ (1998) ainda acrescentaram que o cimento agiria com agente lubrificante, permitindo ligeiros 
movimentos da coroa durante o assentamento, seguindo o direcionamento da força aplicada.

O assentamento oblíquo permite exposição de maior área de cimento em um determinado ponto da coroa. O exato significado clínico do assentamento oblíquo ainda não é conhecido, embora seja bastante racional concluir que ele não é desejável. Cabe ao clínico minimizar sua ocorrência controlando o espaço interno das coroas, bem como a técnica de cimentação. Coroas cimentadas com elevado assentamento oblíquo terão margens significantemente mais abertas do que outras. Estes grandes desajustes marginais podem estar mais propensos à falha no cimento e subseqüente incidência de cárie ou inflamação gengival. Como a espessura da película do cimento também se torna bastante variável, algumas áreas deste sofrerão maior estresse quando sob tensão (EAMES et al. $\left.{ }^{23}, 1978\right)$

Os resultados deste trabalho mostraram uma tendência de desajuste positivo para a face lingual e desajuste negativo para as faces vestibular, mesial e distal das i.es. (tabelas 5.12 e 5.14). A ocorrência poderia ser justificada pelo direcionamento nãoaxial das forças de cimentação, despretensiosamente induzido pela pressão digital do operador.

A ocorrência de assentamento oblíquo também foi relatada por WHITE; KIPNIS ${ }^{89}$ (1993). Para eles, o valor relativo de assentamento oblíquo de um espécime é dependente do número de pontos medidos ao redor deste e 3 pontos seriam o mínimo necessário para descrever um plano de inclinação. Desta forma, parece não ter sido correta a mensuração de QUINTAS; OLIVEIRA; BOTTINO ${ }^{71}$ (2004) e de CHAN et al. ${ }^{13}$ (2004) que avaliaram o fenômeno observando, respectivamente, em uma e duas das faces das coroas sobre um troquel metálico. 
Entretanto, de forma oposta ao encontrado, $\operatorname{PASCOE}^{62}$ (1983) ao avaliar um modelo bidimensional coroa/troquel, não observou evidências de assentamento assimétrico das coroas.

PILO; CARDASH ${ }^{66}$ (1998) sugeriram que esforços para minimizar o assentamento oblíquo deveriam centrar-se na diminuição do desajuste interno das coroas e na confecção de sulcos axiais que orientassem a inserção das mesmas.

Quanto à ocorrência de sobre-assentamento dos corpos de prova deste estudo, é importante considerar que este fenômeno foi relatado em coroas metálicas com média de $14 \mu \mathrm{m}$ (ROSENSTIEL; GEGAUFF ${ }^{73}$, 1988) e 18,5 $\mu \mathrm{m}$ (GEGAUFF; ROSENSTIEL ${ }^{29}$, 1989). GRAJOWER; LEWINSTEIN; ZELTSER ${ }^{32}$ (1985) e WILSON et al. ${ }^{94}$ (1990) observaram o sobre-assentamento em alguns corpos de prova, mesmo quando a carga de assentamento inicial era igual à carga de cimentação.

GEGAUFF; ROSENSTIEL ${ }^{29}$ (1989) hipotetizaram que o sobre-assentamento pode ocorrer quando: 1) após a remoção da carga, sendo possível que o cimentoanálogo com reação de presa completa, possa ter impedido o rebote das i.es., estas tenham sido mantidas em uma posição ligeiramente além da posição inicial; 2) tenha havido ligeira abrasão ou deformação das i.es. durante a cimentação; 3) o fenômeno pode não ter ocorrido realmente, sendo o método de mensuração utilizado insuficientemente preciso. WILSON et al..$^{94}$ (1990) ainda explicaram que o fenômeno talvez pode ser conseqüência de certa propriedade lubrificante dos cimentos.

A maioria dos trabalhos a respeito de espessura de linha de cimento está relacionada a restaurações metálicas fundidas, sendo que pouco se sabe sobre a película sob coroas totalmente cerâmicas. Trabalhos de avaliação a respeito de i.es. de sistemas cerâmicos são de curto prazo, ainda não podendo ser considerados bem sucedidos e confiáveis (PRÖBSTER ${ }^{68}, 1996$, BOENING et al. ${ }^{9}, 2000$ e ÖDMAN; ANDERSSON $^{59}$, 2001). 
A espessura da película de cimento é um fenômeno complexo que, para ØILO; $\operatorname{EVJE}^{60}$ (1986), inclui fatores como a reologia dos cimentos e o tamanho de suas partículas, a força aplicada durante a cimentação e a geometria e o aspecto superficial do preparo dental.

Muitos estudos acerca de ajuste de coroas adotaram o bem sucedido método não-destrutivo descrito por McLEAN; von FRAUNHOFER ${ }^{57}$, em 1971, que utiliza um material elastomérico como agente simulador de cimentação, que possui tempo de trabalho, escoamento e tempo de presa semelhantes aos do cimento de fosfato de zinco, sendo capaz de produzir uma película de $22 \mu \mathrm{m}$, muito próxima do valor esperado para o fosfato de zinco $(20 \mu \mathrm{m})$. Desta forma, foi teorizado que o cimentoanálogo agiria como um modelo adequado de pesquisa. Entretanto, a técnica proposta exige o seccionamento da película do elastômero para a mensuração de sua espessura e, conseqüentemente, a avaliação fica limitada ao plano de secção. Apesar disso, SHEARER; GOUGH; SETCHELL ${ }^{78}$ (1996), ao avaliar espessura de película sob i.es. do sistema In-Ceram, observaram que o plano de secção (vestíbulo-lingual ou mesio-distal) não resultava em diferença significantemente na avaliação.

A espessura de película de silicone fluido obtida por DAVIS; KELLY; CAMPBELL $^{18}$ (1989) ao assentar coroas metálicas sobre seus respectivos troquéis de resina epóxica, foi estatisticamente semelhante àquela obtida quando estas foram cimentadas com cimento de fosfato de zinco sobre os mesmos troquéis. Resultados semelhantes também foram observados por KELLY; DAVIS; CAMPBELL ${ }^{50}$ (1989), quando avaliaram a película de silicone por técnica de reflexão relativa óptica. Isto, mais uma vez, demonstra que o silicone fluido pode ser usado como ferramenta apropriada para a simulação da cimentação das i.es. 
A espessura de película média encontrada nas paredes axiais (média das regiões I e II) para grupo MC (47 $\mu \mathrm{m}$ - tabela 5.9) está de acordo com as dimensões recomendadas pelos autores anteriormente citados. Entretanto, os resultados para os grupos IZ (79 $\mu \mathrm{m}$ - tabela 5.10) e PZ (75 $\mu \mathrm{m}$ - tabela 5.11) foram superiores, o que pode significar redução da capacidade retentiva, caso o cimento utilizado abaixo destas seja o fosfato de zinco. Apesar disso, estudando espessura de película em coroas de pré-molares, mantidas em função por pelo menos 10 anos, PILO; CARDASH ${ }^{66}$ (1998) encontraram valor médio de $79 \mu \mathrm{m}$ nas paredes axiais, enquanto KARLSSON ${ }^{47}$ (1993) e MAY et al..$^{55}$ (1998) encontraram, in vitro, espessura média de $110 \mu \mathrm{m}$ e $69 \mu \mathrm{m}$, respectivamente, para as mesmas paredes. A figura 6.1 exemplifica a espessura média típica encontrada para cada um dos grupos.

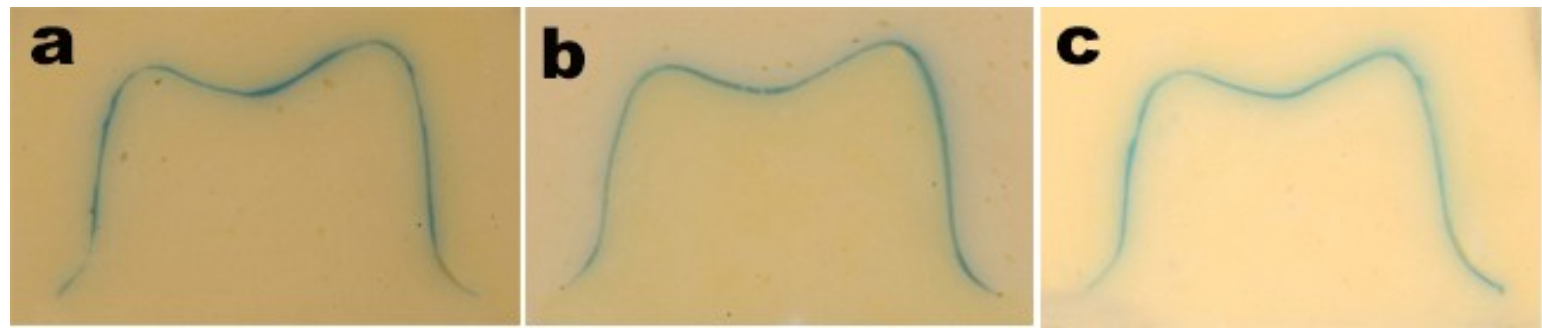

FIGURA 6.1 - representação da espessura média típica encontrada para os grupos MC (a), IZ (b) e PZ (c)

FRANSSON; ØILO; GJEITANGER ${ }^{26}$ (1985) observaram que a espessura média da linha de cimento, abaixo de coroas fundidas em liga áurea, ao longo das paredes axiais, encontrava-se acima de $100 \mu \mathrm{m}$.

$\operatorname{AYUB}^{5}$ (2002) encontrou para i.es. metálicas espessura de película nas paredes axiais $(41 \mu \mathrm{m})$ semelhante à encontrada neste trabalho $(47 \mu \mathrm{m})$; na superfície oclusal encontrou maior valor $(128 \mu \mathrm{m})$ do que aqui encontrado (69 $\mu \mathrm{m}$ - média das regiões III 
e IV - tabela 5.9). Para as i.es. do sistema In-Ceram Alumina, encontrou valores nas paredes axiais de $54 \mu \mathrm{m}$ e de $137 \mu \mathrm{m}$ na superfície oclusal, enquanto os valores encontrados neste trabalho para as i.es. de In-Ceram Zirconia foram de $79 \mu \mathrm{m}$ e $64 \mu \mathrm{m}$, respectivamente (tabela 5.10). Para as i.es. do sistema Procera, encontrou valores de $110 \mu \mathrm{m}$ e $190 \mu \mathrm{m}$, enquanto os encontrados aqui para as i.es. de Procera AllZircon foram de $75 \mu \mathrm{m}$ e $94 \mu \mathrm{m}$ (tabela 5.11) para as superfícies axiais e oclusal, respectivamente. MAY et al. ${ }^{55}$ (1998) observaram linha de película na superfície oclusal de $42 \mu \mathrm{m}$ para o sistema Procera AllCeram e BOENING et al..$^{9}$ (2000) encontraram 181 $\mu \mathrm{m}$ na mesma superfície.

NEIVA et al. ${ }^{58}$ (1998) observaram que os sistemas Procera AllCeram e In-Ceram Alumina demonstram valor semelhante de linha de cimento na superfície oclusal (140 $\mu \mathrm{m}$ e $145 \mu \mathrm{m}$, respectivamente), entretanto, nas paredes axiais o valor foi maior para o sistema Procera $(105 \mu \mathrm{m})$ do que para o sistema In-Ceram $(45 \mu \mathrm{m})$.

Os numerosos métodos existentes para avaliar a precisão do ajuste ainda provêem informações limitadas. A comparação direta dos dados de diferentes estudos é, geralmente, muito difícil. O grande número de variáveis experimentais como diferentes materiais avaliados, diferentes agentes de cimentação e diferentes técnicas de mensuração, torna complexo o cruzamento de dados disponíveis sobre o assunto.

Um melhor assentamento das coroas com adequado espaço para o cimento pode ser atribuído ao decréscimo na força hidrostática sobre a película de cimento, a melhora no escoamento e a redução na retenção friccional (CARTER; WILSON ${ }^{12}$, 1997). JøRGENSEN ${ }^{43}$ (1960b) postulou que a natureza de duas fases (partículas e líquido) do cimento de fosfato de zinco pode ter significante efeito no assentamento das coroas, mostrando que as partículas no cimento agregavam-se em grumos de até 100 $\mu \mathrm{m}$ de diâmetro. Ele considerou que os grumos mais viscosos interfeririam 
significantemente no assentamento das coroas, além de que estes, quando espremidos entre as paredes, agiriam como um filtro para o componente líquido do cimento. Entretanto, GRAJOWER; LEWINSTEIN; ZELTSER ${ }^{32}$, em 1985, demonstraram que a espessura de película pode ser menor que o tamanho destes agregados de partículas. Estes encontraram, abaixo de coroas cimentadas sobre troquéis com cimento de fosfato de zinco, espessura mínima de película igual a $4 \mu \mathrm{m}$. Da mesma forma, foi possível encontrar neste trabalho espessura de $7 \mu \mathrm{m}$ de película sob a i.e. 10 do grupo MC (tabela 5.6).

$\varnothing I L O ;$ EVJE$^{60}$ (1986) encontraram que a película de cimento obtida em uma situação coroa-troquel com perfuração oclusal foi menor do que aquela encontrada usando placas de vidro, conforme o teste da ADA. Nesta situação, eles consideraram que o primeiro modelo de cimentação envolvia a aplicação de maior força de compressão sobre o cimento que o modelo da ADA. Para eles, as forças que promovem o escoamento do cimento atuam de forma diferente sobre o fluido em cada um dos modelos. O componente de força paralelo à direção de escoamento é maior no modelo coroa-troquel do que entre as duas placas de vidro. Resultados semelhantes também foram encontrados por JøRGENSEN; PETERSEN ${ }^{45}$ (1963), HEMBREE; GEORGE; HEMBREE $^{34}$ (1978) e WINDELER ${ }^{98}$ (1979).

Desde 1963, JØRGENSEN; PETERSEN ${ }^{45}$ acreditavam que as especificações n.8 da ADA estariam mais relacionadas à viscosidade do cimento do que à sua espessura de película. Esta afirmação foi ainda sustentada por JØRGENSEN; ESBENSEN $^{44}$ (1968), WINDELER ${ }^{98}$ (1979) e $\varnothing I L O ;$ EVJE$^{60}$ (1986). Para de la MACORRA; PRADÍES ${ }^{53}$ (2002), esta especificação deveria ser revista, pois novos materiais de prótese têm diferentes necessidades e aplicações, além de que a maioria 
dos materiais adesivos incorpora características que são diferentes às dos cimentos de ação friccional.

A espessura de película está relacionada à dimensão e à inclinação das paredes do preparo, tipo de cimento e artifícios que auxiliem seu escoamento. Outros fatores como tamanho e o formato das partículas, relação pó/líquido, temperatura da mistura, pressão de cimentação e o substrato contra o qual o cimento é testado influenciam diretamente sobre o assentamento de uma coroa (WHITE; YU ${ }^{92}$, 1992b e WHITE; YU; $\mathrm{KIPNIS}^{93}$, 1992). Sob superfícies metálicas ou dentina, a espessura de película tende a ser significante menor do que quando sob superfícies de vidro (WHITE; YU ${ }^{91}$, 1992a e STRUTZ et al. $\left.{ }^{81}, 1994\right)$. JØRGENSEN ${ }^{42}$ (1960a) observou que um aumento da pressão de cimentação reduzia a espessura da linha de cimento consideravelmente, porém, um aumento além de $5 \mathrm{Kg}$, seria de relativa insignificância. Considerou, também, que prolongar a pressão por mais que um minuto, seria sem efeito.

STRUTZ et al. ${ }^{81}$ (1994) encontraram que diferentes tipos de cimentos e o substrato contra o qual os cimentos foram testados tiveram significante efeito sobre a espessura de película. Entretanto, o efeito causado pelo tipo de cimento teve maior significância e magnitude que o substrato do experimento. A relação entre a taxa de insucesso de coroas e a espessura da linha de cimento ainda não foi estabelecida por estudos clínicos (WU; WILSON $\left.{ }^{100}, 1994\right)$.

A linha de cimento idealmente deveria ser um espaço uniforme para não comprometer a retenção e a forma de resistência de uma coroa. Isto é de grande importância para as i.es. cerâmicas, já que estas são mais frágeis do que as i.es. metálicas. A espessura da linha de cimento abaixo de uma coroa pode influenciar seu prognóstico clínico (MAY et al. ${ }^{55}, 1998$ e ROSENSTIEL; LAND; CRISPIN ${ }^{74}$, 1998). Pode também influenciar a retenção das mesmas. Perda de retenção é tida para SCHWARTZ et al. $^{76}$ (1970) como a segunda maior causa de falhas em coroas totais. Em 1968, 
JØRGENSEN; ESBENSEN ${ }^{44}$ encontraram que a resistência do cimento diminui aproximadamente em um terço quando sua espessura aumenta de $20 \mu \mathrm{m}$ para $120 \mu \mathrm{m}$. JUNTAVEE; MILLSTEIN ${ }^{46}$ (1992) observaram que $150 \mu \mathrm{m}$ de espaço para o cimento promoveu significantemente menos retenção que espessuras de $50 \mu \mathrm{m}$ e $100 \mu \mathrm{m}$. Por sua vez, EAMES et al. ${ }^{23}$ (1978) encontraram que coroas confeccionadas com espaçadores de troquel apresentavam $25 \%$ mais retenção do que aquelas confeccionadas sem alívio; o volume de alívio sugerido está entre $20 \mu \mathrm{m}$ e $40 \mu \mathrm{m}$. Para eles, o alívio de áreas internas de estresse seria uma explicação para seus achados. Entretanto, quanto ao uso de espaçadores de troquéis GEGAUFF; ROSENSTIEL ${ }^{29}$ (1989) encontraram que esta prática não melhorava o assentamento de coroas cimentadas com carga dinâmica. Da mesma forma, CARTER; WILSON ${ }^{12}$ (1997) levantaram trabalhos que advertiram sobre o uso dos espaçadores, os quais tenderiam à formação de uma camada irregular de espaço, produzindo coroas fundidas com variações não intencionais no espaço interno para o cimento.

Forças oblíquas que incidam sobre a coroa submetem a linha de cimento a esforços de cisalhamento. Películas de cimento muito delgadas falham por força de cisalhamento, sendo que a resistência ao cisalhamento é seis vezes maior que a resistência à tração $\left(\right.$ SCHWARTZ $\left.{ }^{77}, 1986\right)$. Por outro lado, películas espessas falham por força de tração (IIZUKA et al. ${ }^{39}$, 1987). McINTYRE et al. ${ }^{56}$ (1994) demonstraram que películas menores que $50 \mu \mathrm{m}$ exibiram menor resistência ao cisalhamento do que películas de espessura superior. Dados similares foram publicados por $\varnothing I L O ; E^{2} E^{60}$ (1986), justificando que o fato estaria ligado à estrutura da película de cimento e as imperfeições contidas no interior desta.

Avaliando superfícies metálicas planas cimentadas com cimentos resinosos, CHANA et al. ${ }^{14}$ (1997) concluíram que quando a espessura de película aumentava, a 
resistência à tração diminuía. De forma semelhante, WISKOTT; BELSER; SCHERRER $^{99}$ (1999) também observaram que a resistência à carga lateral de cisalhamento diminuía à medida que a espessura da linha de cimento aumentava, independentemente do tipo de cimento utilizado. Para explicar este fenômeno, os autores citaram a teoria das falhas de Griffith, que diz: 1) todos os materiais contêm defeitos aleatoriamente distribuídos em seu interior; 2) sob carga, cada um destes defeitos é capaz de dar início à propagação de trincas; 3) quanto maior o volume de material, mais numerosos são os defeitos e maior a probabilidade de iniciação de trincas. CHANA et al. ${ }^{14}$ (1997) creditaram seus resultados à presença de maior número de bolhas nas linhas mais espessas de cimento. Desta forma, talvez possa ser explicada a reduzida resistência de camadas espessas de cimento.

DIAZ-ARNOLD; WILLIAMS; AQUILINO ${ }^{20}$ (1991) encontraram que quanto maior a espessura da película do cimento resinoso, maiores as bolhas presentes em seu interior. Demonstraram, também, que a adequada resistência destes cimentos deu-se sob $80 \mu \mathrm{m}$ de espessura. SCHERRER et al. ${ }^{75}$ (1994) afirmaram que uma estrutura cerâmica estaria sujeita à fratura apenas a partir de $300 \mu \mathrm{m}$ de espessura de cimentos resinosos, em avaliação laboratorial conduzida sobre placas cerâmicas quadradas, cimentadas sobre blocos de resina.

BLATZ $^{8}$ (2004) comentou sobre a possibilidade de cimentação de coroas totalmente cerâmicas com cimentos de fosfato de zinco e ionômero de vidro. Porém, sinalizou a preferência de alguns pesquisadores em indicar cimentação adesiva para as mesmas, justificando a opção pelo aumento da retenção e da resistência das coroas. A película média encontrada para as i.es. cerâmicas deste trabalho mostra compatibilidade com a espessura produzida pelos cimentos resinosos (WHITE; YU ${ }^{92}$, 1992b). 
Cada tipo de cimento pode produzir uma determinada espessura de película, fazendo com que se necessite de diferentes espaços pré-cimentação, dependendo do cimento, para assegurar o devido assentamento das coroas (WHITE; YU $\left.{ }^{92}, 1992 b\right)$. Tem sido demonstrado que os cimentos resinosos promovem espessura de película menos uniforme e maior desajuste decorrente da cimentação do que outros tipos de cimentos (WHITE; YU ${ }^{92}$, 1992b e WHITE; KIPNIS ${ }^{89}$, 1993). Isto presumidamente ocorreria devido a maior viscosidade dos cimentos resinosos (ROSENSTIEL; LAND; CRISPIN $^{74}$, 1998). A maioria dos cimentos resinosos contém de 50 a $70 \%$ de sílica e a alta concentração deste componente de carga aumenta a viscosidade do material, reduzindo seu escoamento e aumentando a espessura de película (DIAZ-ARNOLD; VARGAS; HASELTON ${ }^{21}$, 1999). Dentre os cimentos resinosos avaliados por WHITE; $\mathrm{YU}^{92}$ (1992b) todos apresentaram película entre 40 e $107 \mu \mathrm{m}$.

ROSENSTIEL; LAND; CRISPIN ${ }^{74}$ (1998) indicaram para a cimentação de coroas cerâmicas os cimentos de ionômero de vidro, fosfato de zinco e resinoso, contraindicando o uso dos cimentos ionoméricos modificados por resina. Porém de la MACORRA; PRADÍES ${ }^{53}$ (2002) comentaram não mais haver qualquer tipo de contraindicação para os cimentos de ionômero de vidro modificados por resina na cimentação de coroas totalmente cerâmicas.

A observação das tabelas 5.6, 5.7 e 5.8 faz perceber a grande variação na espessura de película abaixo de todos os espécimes. Faz perceber, também, a não uniforme distribuição dos valores em cada ponto de medida. As tabelas 5.15, $5.16 \mathrm{e}$ 5.17 mostram a grande variação e os altos valores de desvio-padrão para a espessura de película, especialmente para os grupos IZ e PZ. Achados semelhantes também foram relatados por GRAJOWER; LEWINSTEIN; ZELTSER ${ }^{32}$ (1985), KARLSSON ${ }^{47}$ (1993) e AYUB $^{5}$ (2002). 
Considerando a espessura média de película de cada grupo, a análise de variância a 1 critério demonstrou diferença estatística entre os grupos. $O$ teste de Tukey (tabela 5.22) apontou a espessura de película do grupo PZ, como estatisticamente maior do que aquela do grupo MC; entretanto, o grupo MC apresentou espessura semelhante ao grupo $\mathrm{IZ}$.

A ocorrência de interação estatística entre as i.es. demonstra que apesar de ter existido diferença estatística entre os grupos e entre as regiões medidas, esta ocorreu em diferentes localizações da película e em diferentes tipos de coroas. Necessariamente, não houve diferenças entre os grupos em todas as regiões mensuradas, bem como nem todas as regiões foram diferentes em todos os grupos. Este achado também está de acordo com os resultados de AYUB $^{5}$ (2002).

A observação das tabelas 5.3, 5.4 e 5.5 faz perceber que houve diferença nos valores de assentamento oblíquo entre os grupos avaliados. A variação dos valores médios de desajuste para as i.es. do grupo PZ foi maior do que a observada para 0 grupo MC. A análise do comportamento das faces das i.es. do grupo MC, quanto ao desajuste, detecta variação de -14 a $11 \mu \mathrm{m}$ para as faces vestibular/lingual e -9 a -6 $\mu \mathrm{m}$ para as faces mesial/distal, respectivamente. Para o grupo PZ houve, respectivamente, uma variação de -51 a $13 \mu \mathrm{m}$ para as faces vestibular/lingual e -24 a $-2 \mu \mathrm{m}$ para as faces mesial/distal. Levando em consideração a espessura média de película dos grupos avaliados (tabela 5.21) observa-se que ocorreu maior inclinação das i.es. com maior espessura de película. A figura 6.2 mostra exemplos de assentamento oblíquo para cada um dos grupos. 

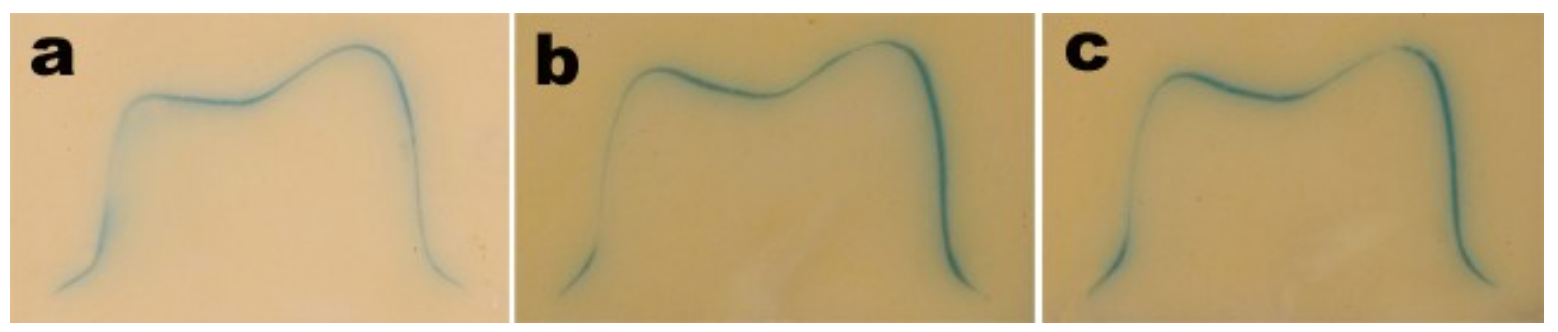

FIGURA 6.2 - exemplos de assentamento oblíquo dos grupos MC (a), IZ (b) e PZ (c)

Para se verificar a correlação entre espessura de película e desajuste vertical foi utilizado o coeficiente de correlação de Pearson, obtendo-se $r=-0,26 ; p=0,173$, sendo o resultado estatisticamente não significante. Desta forma, do ponto de vista matemático, não se podem extrapolar os resultados obtidos, frente ao número de espécimes aqui utilizados, de maneira generalizada. Entretanto, os resultados mostram uma tendência de fraca correlação negativa $(r=-0,26)$, com moderado alinhamento entre os pontos de correlação (figura 5.3).

O grupo PZ apresentou o maior valor médio de espessura de película (84 $\mu \mathrm{m}$ tabela 5.21) e o menor valor médio de desajuste vertical (-16 $\mu \mathrm{m}$ - tabela 5.5) dentre os três grupos. Os grupos MC e IZ foram estatisticamente semelhantes entre si para espessura de película e desajuste vertical. Desta forma, observa-se que o grupo com maior espessura de película desajustou-se estatisticamente menos do que os demais grupos com menor espessura. Isto demonstra a tendência de que coroas com menor retenção friccional resultam em maior espaço interno e maior espessura de película e, por sua vez, sob menor influência da pressão hidrostática e das propriedades reológicas dos cimentos, desajustam-se menos durante a cimentação, gerando inclusive sobreassentamento.

Talvez, para esta relação apresentar-se mais clara fosse necessário haver maior diferença de espessura de película entre os grupos. Entretanto, a variação de espessura entre os valores extremos foi de apenas $26 \mu \mathrm{m}$. Os altos valores de desvio- 
padrão, tanto para desajuste vertical quanto para espessura de película, sugerem que outros fatores, além daqueles relacionados às técnicas de confecção das i.es., podem ter influenciado os resultados obtidos. Possivelmente, estes fatores estariam ligados à técnica de cimentação e às propriedades hidrodinâmicas do cimento-análogo.

Apesar de diversos trabalhos mostrarem o sucesso clínico e qualidade marginal dos sistemas In-Ceram (PRÖBSTER ${ }^{67}$, 1993, PRÖBSTER ${ }^{68}$, 1996, BESCHNIDT; STRUB $^{7}, 1999$ e OLSSON et al. ${ }^{61}, 2003$ ) e Procera (SULAIMAN et al. ${ }^{82}, 1997$ e ÖDMAN; ANDERSSON ${ }^{59}, 2001$ ), ainda não existem estudos clínicos controlados sobre i.es. de óxido de zircônio que demonstrem sucesso em longo prazo, apesar de que previsões revelaram taxas de sucesso favoráveis (FISCHER; WEBER; MARX ${ }^{25}, 2003$ ).

O que se pôde perceber é que, mesmo sendo o processo de produção das i.es. do sistema Procera AllZircon (grupo PZ) automatizado, este não foi capaz de produzir espaço interno médio menor que as i.es. metálicas (grupo MC), confeccionadas em laboratório e sujeitas às habilidades manuais de um técnico em prótese. Uma possível explicação pode estar relacionada ao processo de fabricação do troquel refratário do sistema Procera AllZircon. A possibilidade de erro no cálculo do sistema CAD/CAM ao fabricar o troquel refratário com 15 a 20\% de aumento (ANDERSSON; ODÉN ${ }^{3}, 1993$ ) pode ter influenciado na fidelidade da superfície interna da i.e. em relação ao troquel original.

Apesar de PERSSON; ANDERSSON; BERGMAN ${ }^{64}$ (1995) terem encontrado alta precisão para o dispositivo de leitura do sistema Procera, é importante lembrar que este é bastante sensível às irregularidades do preparo. A ponta de safira do leitor do escandidor possui $2,5 \mathrm{~mm}$ de diâmetro e, teoricamente, não conseguiria localizar irregularidades ou sulcos com raio menor que $1,25 \mathrm{~mm}$. 
Outras avaliações, além dos propósitos deste trabalho, serão necessárias para determinar a real influência do processo de fabricação e do dispositivo de leitura sobre o espaço interno das i.es. do sistema Procera AllZircon. 


\section{CONCLUSÕES}




\section{CONCLUSÕES}

A partir dos resultados pôde-se concluir que:

1. O ajuste interno das infra-estruturas metalo-cerâmicas e In-Ceram Zirconia resultou em redução do desajuste vertical;

2. O desajuste vertical das infra-estruturas Procera AllZircon foi estatisticamente diferente das infra-estruturas metalo-cerâmicas e In-Ceram Zirconia;

3. A espessura de película das infra-estruturas Procera AllZircon foi significantemente maior que das infra-estruturas metalo-cerâmicas e In-Ceram Zirconia;

4. Todas as infra-estruturas apresentaram assentamento oblíquo. 


\section{REFERÊNCIAS BIBLIOGRÁFICAS}




\section{REFERÊNCIAS BIBLIOGRÁFICAS}

1. ABBATE, M.F.; TJAN, A.H.; FOX, W.M. Comparison of the marginal fit of various ceramic crown systems. J Prosthet Dent, v.61, n.5, p.527-31, May 1989.

2. AMERICAN NATIONAL STANDARDS INSTITUTE / AMERICAN DENTAL ASSOCIATION. Specification n.8 for Zinc Phosphate Cements. J Am Dent Assoc, v.96, n.3, p.432-7, Mar. 1978.

3. ANDERSSON, M.; ODÉN, A. A new all-ceramic crown. A dense-sintered, high-purity alumina coping with porcelain. Acta Odontol Scand, v.51, n.1, p.59-64, Feb. 1993

4. ARAKELIAN, A.Jr. A technique for seating castings. J Prosthet Dent, v.48, n.3, p.357, Sept. 1982.

5. AYUB, E.A. Avaliação da espessura de película de infra-estruturas de quatro sistemas cerâmicos. Bauru, 2002. 130p. Dissertação (mestrado) - Universidade do Sagrado Coração.

6. BASSETT, R.W. Solving the problems of cementing the full veneer cast gold crown. J Prosthet Dent, v.16, n.4, p.740-7, Jul.-Aug. 1966.

7. BESCHNIDT, S.M.; STRUB, J.R. Evaluation of the marginal accuracy of different all-ceramic crown systems after simulation in the artificial mouth. J Oral Rehabil, v.26, n.7, p.582-93, July 1999.

*Normas recomendadas para uso no âmbito da Universidade de São Paulo, com base no documento "Referências Bibliográficas: exemplos", emanadas do Conselho Supervisor do Sistema Integrado de Bibliotecas da USP, em reunião de 20 de setembro de 1990.

8. BLATZ, M.B. Cementation of zirconium-oxide ceramic restorations. Pract 
Proced Aesthet Dent, v.16, n.1, p.14, Jan.-Feb. 2004.

9. BOENING, K.W. et al. Clinical fit of Procera AllCeram crowns. J Prosthet Dent, v.84, n.4, p.419-24, Oct. 2000.

10. BOLOURI, A.; MARKER, V.A.; SARAMPOTE, R.V. Technique-related variation of cement-film thickness under full crowns. Gen Dent, v.35, n.1, p.26-8, Jan.-Feb. 1987.

11. BYRNE, G. Influence of finish-line form on crown cementation. Int $\mathbf{J}$ Prosthodont, v.5, n.2, p.137-44, Mar.-Apr. 1992.

12. CARTER, S.M.; WILSON, P.R. The effects of die-spacing on postcementation crown elevation and retention. Aust Dent J, v.42, n.3, p.192-8, June 1997.

13. CHAN, D.C. et al. Effect of preparation convergence on retention and seating discrepancy of complete veneer crowns. J Oral Rehabil, v.31, n.10, p.1007-13, Oct. 2004.

14. CHANA, H.S. et al. The influence of cement thickness on the tensile strength of two resin cements. Int J Prosthodont, v.10, n.4, p.340-4, July-Aug. 1997.

15. CHONG, K.H. et al. Flexural strength of In-Ceram alumina and In-Ceram zirconia core materials. Int J Prosthodont, v.15, n.2, p.183-8, Mar.-Apr. 2002.

16. CHRISTENSEN, G.J. Marginal fit of gold inlay castings. J Prosthet Dent, v.16, n.2, p.297-305, Mar.-Apr. 1966.

17. CHRISTENSEN, G.J. Clinical and research advancements in cast-gold restorations. J Prosthet Dent, v.25, n.1, p.62-8, Jan. 1971.

18. DAVIS, S.H.; KELLY, J.R.; CAMPBELL, S.D. Use of an elastomeric material 
to improve the occlusal seat and marginal seal of cast restorations. $\mathbf{J}$ Prosthet Dent, v.62, n.3, p.288-91, Sept. 1989.

19. DEDMON, H.W. Disparity in expert opinions on size of acceptable margin openings. Oper Dent, v.7, n.3, p.97-101, Summer 1982.

20. DIAZ-ARNOLD, A.M.; WILLIAMS, V.D.; AQUILINO, S.A. The effect of film thickness on the tensile bond strength of a prosthodontic adhesive. $\mathbf{J}$ Prosthet Dent, v.66, n.5, p.614-8, Nov. 1991.

21. DIAZ-ARNOLD, A.M.; VARGAS, M.A.; HASELTON, D.R. Current status of luting agents for fixed prosthodontics. J Prosthet Dent, v.81, n.2, p.13541, Feb. 1999.

22. DIMASHKIEH, M.R.; DAVIES, E.H. ; von FRAUNHOFER, J.A. Measurement of the cement film thickness beneath full crown restorations. Br Dent $\mathbf{J}$, v.137, n.7, p.281-4, Oct. 1974.

23. EAMES, W.B. et al. Techniques to improve the seating of castings. J Am Dent Assoc, v.96, n.3, p.432-7, Mar. 1978.

24. FELTON, D.A. et al. Effect of in vivo crown margin discrepancies on periodontal health. J Prosthet Dent, v.65, n.3, p.357-64, Mar. 1991.

25. FISCHER, H.; WEBER, M.; MARX, R. Lifetime prediction of all-ceramic bridges by computational methods. J Dent Res, v.82, n.3, p.238-42, Mar. 2003.

26. FRANSSON, B.; ØILO, G.; GJEITANGER, R. The fit of metal-ceramic crowns, a clinical study. Dent Mater, v.1, n.5, p.197-9, Oct. 1985.

27. FUSAYAMA, T.; IWAMOTO, T. Optimum cement film thickness for maximum shear resistence between teeth and restorations. Bull Tokyo Med Dent Univ, v.8, n.1, p.147-64, June 1961. 
28. FUSAYAMA, T. et al. Cement thickness between cast restorations and preparation walls. J Prosthet Dent, v.13, n.2, p.354-64, Mar.-Apr. 1963.

29. GEGAUFF, A.G.; ROSENSTIEL, S.F. Reassessment of die-spacer with dynamic loading during cementation. J Prosthet Dent, v.61, n.6, p.6558, June 1989.

30. GIORDANO II, R. A comparison of all-ceramic restorative systems: Part 2. Gen Dent, v.48, n.1, p.38-45, Jan.-Feb. 2000.

31. GRAJOWER, R.; LEWINSTEIN, I. A mathematical treatise on the fit of crown castings. J Prosthet Dent, v.49, n.5, p.663-74, May 1983.

32. GRAJOWER, R.; LEWINSTEIN, I.; ZELTSER, C. The effective minimum cement thickness of zinc phosphate cement for luted non-precious crowns. J Oral Rehabil, v.12, n.3, p.235-45, May 1985.

33. GREY, N.J.; PIDDOCK, V.; WILSON, M.A. In vitro comparison of conventional crowns and a new all-ceramic system. J Dent, v.21, n.1, p.47-51, Feb. 1993.

34. HEMBREE, J.H.Jr.; GEORGE, T.A.; HEMBREE, M.E. Film thickness of cements beneath complete crowns. J Prosthet Dent, v.39, n.5, p.533-5, May. 1978.

35. HOARD, R.J. et al. Intracoronal pressure during crown cementation. J Prosthet Dent, v.40, n.5, p.520-5, Nov. 1978.

36. HOBKIRK, J.A. Grinding technique, surface texture and strength of vitreous carbon and high purity alumina. J Dent, v.5, n.3, p.219-26, Sept. 1977. 37. HOLLENBACK, G.M. A practical contribution to the standardization of casting technic. J Am Dent Assoc, v.15, n.10, p.1917-28, Oct. 1928. 38. HOLMES, J.R. et al. Considerations in measurement of marginal fit. $\mathbf{J}$ 
Prosthet Dent, v.62, n.4, p.405-8, Oct. 1989.

39. IIZUKA, $\mathrm{H}$. et al. Forces fracturing cements at die interfaces and their dependence on film thickness. Dent Mater, v.3, n.4, p.187-93, Aug. 1987.

40. ISHIKIRIAMA, A. et al. Influence of some factors on the fit of cemented crowns. J Prosthet Dent, v.45, n.4, p.400-4, Apr. 1981.

41. JANSON, W.A. et al. Preparo de dentes com finalidade protética: técnica da silhueta. Faculdade de Odontologia de Bauru, Bauru - São Paulo, 1986.

42. JØRGENSEN, K.D. Factors affecting the film thickness of zinc phosphate cements. Acta Odontol Scand, v.18, p. 479-90, 1960a.

43. JØRGENSEN, K.D. Structure of the film of zinc phosphate cements. Acta Odontol Scand, v.18, p.491-501, 1960b.

44. JØRGENSEN, K.D.; ESBENSEN, A.L. The relationship between the film thickness of zinc phosphate cement and the retention of veneer crowns. Acta Odontol Scand, v.26, n.3, p.169-75, Aug. 1968.

45. JØRGENSEN, K.D.; PETERSEN, G.F. The grain size of zinc phosphate cements. Acta Odontol Scand, v.21, p.255-70, 1963.

46. JUNTAVEE, N.; MILLSTEIN, P.L. Effect of surface roughness and cement space on crown retention. J Prosthet Dent, v.68, n.3, p.482-6, Sept. 1992.

47. KARLSSON, S. The fit of Procera titanium crowns. An in vitro and clinical study. Acta Odontol Scand, v.51, n.3, p.129-34, June 1993.

48. KAWAI, K.; ISENBERG, B.P.; LEINFELDER, K.F. Effect of gap dimension on composite resin cement wear. Quintessence Int, v.25, n.1, p.53-8, Jan. 1994. 
49. KAY, G.W.; JABLONSKI, D.A.; DOGON, I.L. Factors affecting the seating and fit of complete crowns: a computer simulation study. J Prosthet Dent, v.55, n.1, p.13-8, Jan. 1986.

50. KELLY, J.R.; DAVIS, S.H.; CAMPBELL, S.D. Nondestructive, threedimensional internal fit mapping of fixed prostheses. J Prosthet Dent, v.61, n.3, p.368-73, Mar. 1989.

51. KERN, M.; SCHALLER, H.G.; STRUB, J.R. Marginal fit of restorations before and after cementation in vivo. Int J Prosthodont, v.6, n.6, p.585-91, Nov.-Dec. 1993.

52. KEYS, L.G. An alternate method of verifying the seating of all-ceramic restorations. J Prosthet Dent, v., n., p.411, Apr. 2002.

53. de la MACORRA, J.C.; PRADIES, G. Conventional and adhesive luting cements. Clin Oral Investig, v.6, n.4, p.198-204, Dec. 2002.

54. MARKER, V.A. et al. Factors affecting the retention and fit of gold castings. J Prosthet Dent, v.57, n.4, p.425-30, Apr. 1987.

55. MAY, K.B. et al. Precision of fit: the Procera AllCeram crown. J Prosthet Dent, v.80, n.4, p.394-404, Oct. 1998.

56. McINTYRE, F.M. et al. The effect of film thickness on the bond strength of polycarboxylate cement. Int J Prosthodont, v.7, n.5, p.461-7, Sept.-Oct. 1994.

57. McLEAN, J.W.; von FRAUNHOFER, J.A. The estimation of cement film thickness by an in vivo technique. Br Dent J, v.131, n.3, p.107-11, Aug. 1971.

58. NEIVA, G. et al. Resistance to fracture of three all-ceramic systems. J Esthet Dent, v.10, n.2, p.60-6, 1998. 
59. ÖDMAN, P.; ANDERSSON, B. Procera AllCeram crowns followed for 5 to 10.5 years: a prospective clinical study. Int J Prosthodont, v.14, n.6, p.504-9, Nov.-Dec. 2001.

60. ØILO, G.; EVJE, D.M. Film thickness of dental luting cements. Dent Mater, v.2, n.2, p.85-9, Apr. 1986.

61. OLSSON, K.G. et al. A long-term retrospective and clinical follow-up study of In-Ceram Alumina FPDs. Int J Prosthodont, v.16, n.2, p.150-6, Mar.Apr. 2003.

62. PASCOE, D.F. An evaluation of the marginal adaptation of extracoronal restorations during cementation. J Prosthet Dent, v.49, n.5, p.657-62, May 1983.

63. PERA, P. et al. In vitro marginal adaptation of alumina porcelain ceramic crowns. J Prosthet Dent, v.72, n.6, p.585-90, Dec. 1994.

64. PERSSON, M.; ANDERSSON, M.; BERGMAN, B. The accuracy of a highprecision digitizer for CAD/CAM of crowns. J Prosthet Dent, v.74, n.3, p.223-9, Sept. 1995.

65. PILO, R. et al. Incomplete seating of cemented crowns: a literature review. J Prosthet Dent, v.59, n.4, p.429-33, Apr. 1988.

66. PILO, R.; CARDASH, H.S. In vivo retrospective study of cement thickness under crowns. J Prosthet Dent, v.79, n.6, p.621-5, June 1998.

67. PRÖBSTER, L. Survival rate of In-Ceram restorations. Int J Prosthodont, v.6, n.3, p.259-63, May-June 1993.

68. PRÖBSTER, L. Four year clinical study of glass-infiltrated, sintered alumina crowns. J Oral Rehabil, v.23, n.3, p.147-51, Mar. 1996.

69. PRÖBSTER, L.; DIEHL, J. Slip-casting alumina ceramics for crown and 
bridge restorations. Quintessence Int, v.23, n.1, p.25-31, Jan. 1992.

70. QUALTROUGH, A.J.; PIDDOCK, V. Fitting accuracy of indirect restorations:

a review of methods of assessment. Eur J Prosthodont Restor Dent, v.1, n.2, p.57-61, Dec. 1992.

71. QUINTAS, A.F.; OLIVEIRA, F.; BOTTINO, M.A. Vertical marginal discrepancy of ceramic copings with different ceramic materials, finish lines, and luting agents: an in vitro evaluation. J Prosthet Dent, v.92, n.3, p.250-7, Sept. 2004.

72. RISSIN, L.; WETREICH, G. Utilization of elastomeric materials to evaluate the accuracy of cast restorations prior to cementation. J Prosthet Dent, v.49, n.4, p.585-6, Apr. 1983.

73. ROSENSTIEL, S.F.; GEGAUFF, A.G. Improving the cementation of complete cast crowns: a comparison of static and dynamic seating methods. J Am Dent Assoc, v.117, n.7, p.845-8, Dec. 1988.

74. ROSENSTIEL, S.F.; LAND, M.F.; CRISPIN, B.J. Dental luting agents: A review of the current literature. J Prosthet Dent, v.80, n.3, p.280-301, Sept. 1998.

75. SCHERRER, S.S. et al. Effect of cement film thickness on the fracture resistance of a machinable glass-ceramic. Dent Mater, v.10, n.3, p.172-7, May 1994.

76. SCHWARTZ, N.L. et al. Unserviceable crowns and fixed partial dentures: life-span and causes for loss of serviceability. J Am Dent Assoc, v.81, n.6, p.1395-1401, Dec. 1970.

77. SCHWARTZ, I.S. A review of methods and techniques to improve the fit of cast restorations. J Prosthet Dent, v.56, n.3, p.79-83, Sept. 1986. 
78. SHEARER, B.; GOUGH, M.B.; SETCHELL, D.J. Influence of marginal configuration and porcelain addition on the fit of In-Ceram crowns. Biomater, v.17, n.19, p.1891-5, Oct. 1996.

79. SORENSEN, J.A. A rationale for comparison of plaque-retaining properties of crown systems. J Prosthet Dent, v.62, n.3, p.264-9, Sept. 1989.

80. SORENSEN, J.A. A standardized method for determination of crown margin fidelity. J Prosthet Dent, v.64, n.1, p.18-24, July 1990.

81. STRUTZ, J.M. et al. Luting cement-metal surface physicochemical interactions on film thickness. J Prosthet Dent, v.72, n.2, p.128-32, Aug. 1994.

82. SULAIMAN, F. et al. A comparison of the marginal fit of In-Ceram, IPS Empress, and Procera crowns. Int J Prosthodont, v.10, n.5, p.478-84, Sept.-Oct. 1997.

83. SYU, J.Z. et al. Influence of finish-line geometry on the fit of crowns. Int $\mathbf{J}$ Prosthodont, v.6, n.1, p.25-30, Jan.-Feb. 1993.

84. TAGGART, W.H. A new and accurate method of making gold inlays. Dental Cosmos, v.49, n.11, p.1117-21, Nov. 1907.

85. TAN, K.; IBBETSON, R. The effect of cement volume on crown seating. Int J Prosthodont, v.9, n.5, p.445-51, Sept.-Oct. 1996.

86. TROENDLE, G.R. ; TROENDLE, K.B. ; CAVAZOS, E.Jr. Film thickness of four disclosing media. J Prosthet Dent, v.65, n.6, p.856-7, June 1991.

87. USHIWATA, O. et al. Marginal fit of nickel-chromium copings before and after internal adjustments with duplicated stone dies and disclosing agent. J Prosthet Dent, v.83, n.6, p.634-43, June 2000.

88. WEAVER, J.D.; JOHNSON, G.H.; BALES, D.J. Marginal adaptation of 
castable ceramic crowns. J Prosthet Dent, v.66, n.6, p.747-53, Dec. 1991.

89. WHITE, S.N.; KIPNIS, V. The three-dimensional effects of adjustment and cementation on crown seating. Int J Prosthodont, v.6, n.3, p.248-54, May-June 1993.

90. WHITE, S.N.; SORENSEN, J.A.; KANG, S.K. Improved marginal seating of cast restorations using a silicone disclosing medium. Int J Prosthodont, v.4, n.4, p.323-6, July-Aug. 1991.

91. WHITE, S.N.; YU, Z. Film thickness of new adhesive luting agents. J Prosthet Dent, v.67, n.6, p.782-5, June 1992a.

92. WHITE, S.N.; YU, Z. The effect of adhesive luting agent-dentinal surface interactions on film thickness. J Prosthet Dent, v.68, n.1, p.49-52, July 1992b.

93. WHITE, S.N.; YU, Z.; KIPNIS, V. Effect of seating force on film thickness of new adhesive luting agents. J Prosthet Dent, v.68, n.3, p.476-81, Sept. 1992.

94. WILSON, P.R. et al. Deformation of crowns during cementation. J Prosthet Dent, v.64, n.5, p.601-9, Nov. 1990.

95. WILSON, P.R. Crown behavior during cementation. J Dent, v.20, n.3, p.156-62, June 1992.

96. WILSON, P.R. Effect of increasing cement space on cementation of artificial crowns. J Prosthet Dent, v.71, n.6, p.560-4, June 1994.

97. WILSON, P.R. Low force cementation. J Dent, v.24, n.4, p.269-73, July. 1996.

98. WINDELER, A.S. Powder enrichment effects on film thickness of zinc 
phosphate cement. J Prosthet Dent, v.42, n.3, p.299-303, Sept. 1979.

99. WISKOTT, H.W.; BELSER, U.C.; SCHERRER, S.S. The effect of film

thickness and surface texture on the resistance of cemented extracoronal

restorations to lateral fatigue loading. Int J Prosthodont, v.12, n.3,

p.255-62, May-June 1999.

100. WU, J.C.; WILSON, P.R. Optimal cement space for resin luting cement.

Int J Prosthodont, v.7, n.3, p.209-15, May-June 1994. 


\begin{abstract}
EVALUATION OF VERTICAL MISFIT AND FILM THICKNESS OF THREE CERAMIC SYSTEMS COPINGS
\end{abstract}

The development of new ceramic systems creates the possibility of choice above the type of restoration one could mean to choose. Thus, benefits from this progress must be appraised on the possibility of unsatisfactory clinical behavior. This work intends to evaluate ceramic copings to the influence of internal adjustment on adaptation, vertical misfit after cementation, film thickness of axial and occlusal surfaces and occurrence of oblique seating. A metallic superior premolar analogue with full crown preparation was yield and thirty casts were obtained and divided into three groups of ten specimens each. Metal copings were yield for group MC and ceramics copings of In-Ceram Zirconia and Procera AllZircon were yield for group IZ and group PZ, respectively. The copings had their position, in relation to the metallic analogue, measured during adjustment and cementation with light body silicon. Cement film, below the copings, was sectioned and measured at the axial and occlusal surfaces. The analysis of the results demonstrated that: 1) internal adjustment of metal and In-Ceram Zirconia copings reduced the vertical misfit; 2) vertical misfit after cementation of Procera AllZircon copings was statistically different from metal and In-Ceram Zirconia copings; 3) film thickness of Procera AllZircon copings was significantly greater than metal and In-Ceram Zirconia copings; 4) all copings presented oblique seating.

Key-words: ceramic systems, vertical misfit, film thickness, cementation. 
This document was created with Win2PDF available at http://www.win2pdf.com.

The unregistered version of Win2PDF is for evaluation or non-commercial use only.

This page will not be added after purchasing Win2PDF. 